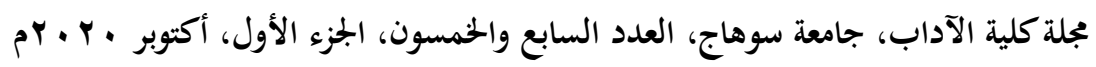

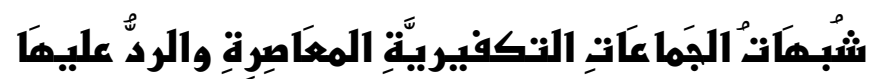

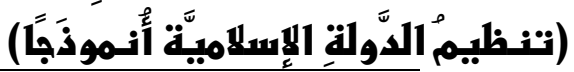

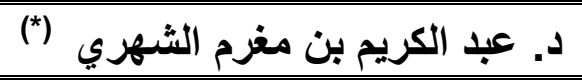

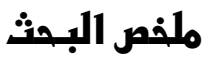

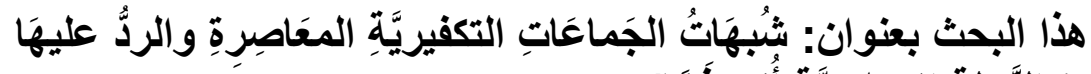

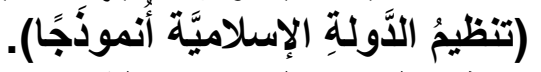

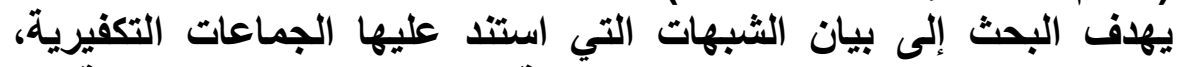

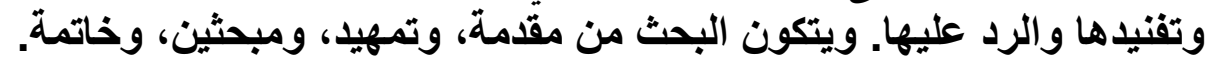

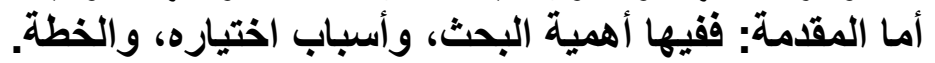

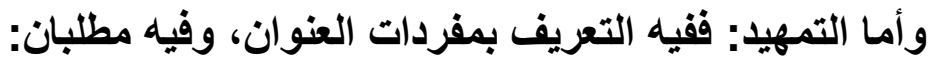

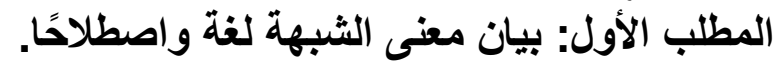
المطلب الثاني: بيان المراد بالجمان المباعات التكفيرية المعاصرة. وأما المباحث: المباني:

المبحث الأول: الثبه المتهُ المبلة بالجهاد والخلافة. المبحث الثاني: الثبه المبه المتعلقة المنعة بالتكفير.

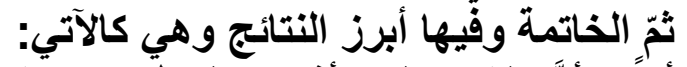

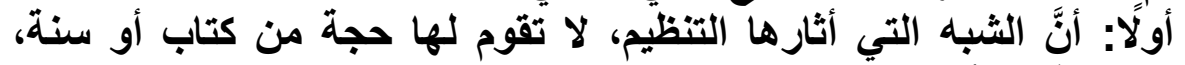

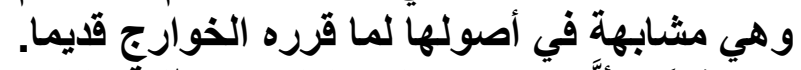

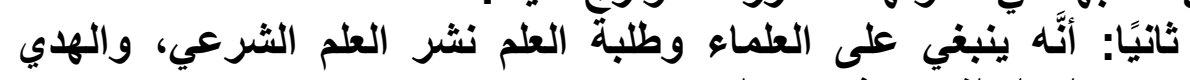

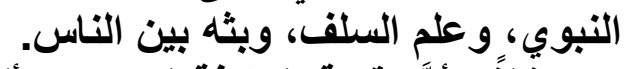

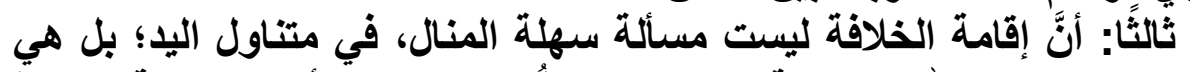

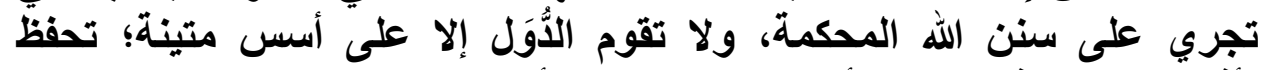

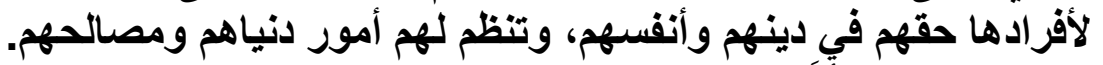

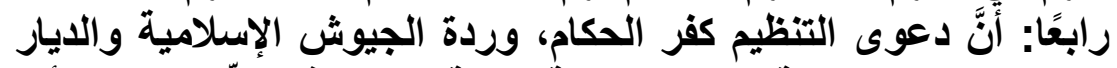

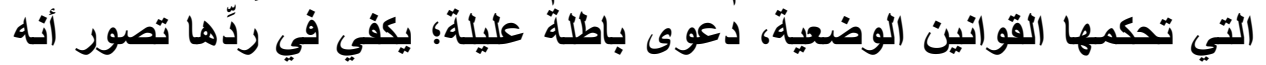

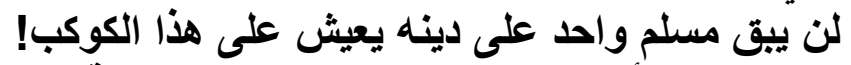

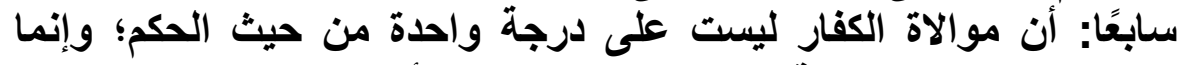

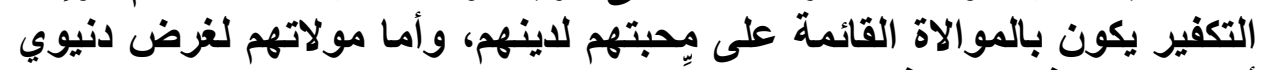
الباحث

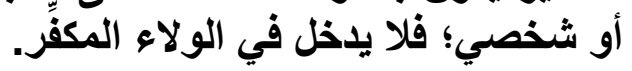




\section{Research Summary}

This research is titled: The quasi-penitential contemporary groups and the response to them (Organization of the Islamic State as a Model).

The research aims to clarify the suspicions on which the takfiri groups relied, and to refute and respond to them. The research consists of an introduction, an introduction, two topics, and a conclusion.

As for the introduction: it contains the importance of the research, the reasons for choosing it, and the plan.

As for the introduction: it defines the vocabulary of the title, and it includes two requirements:

The first requirement: clarification of the meaning of the suspicion in language and idiom.

The second requirement: a statement of what is meant by contemporary takfiri groups. With regard to the mabahith:

The first topic: the similarities related to jihad and the caliphate.

The second topic: the likeness related to atonement.

Then the conclusion and the most prominent results are as follows:

First: The similarities raised by the organization do not have an argument from a book or Sunnah, and it is similar in its origins to what the Kharijites decided in the past.

Second: That the scholars and students of knowledge should spread the legal knowledge, the prophetic guidance, and the knowledge of the ancestors, and spread it among the people.

Third: The establishment of the caliphate is not an easy matter at hand. Rather, it is based on the courtly laws of God, and states are only established on solid foundations. It preserves for its members their right to their religion and themselves, and organizes for them their worldly affairs and interests.

Fourth: That the organization's case for infidelity of rulers, the apostasy of Islamic armies and homes governed by man-made laws, is a null and void lawsuit. In her response, it suffices to imagine that there will not be a single Muslim who lives on this planet!

Seventh: The loyalty of the infidels is not at one level in terms of governance. Rather, the atonement is done through loyalty based on their love for their religion, and as for their mistress for a secular or personal purpose. It does not enter into the loyalty of the unbeliever. 
إنَّ الحمد لله نحمده، ونستعينه ونستغفره، ونعوذ بالله من شرور أنفسنا،

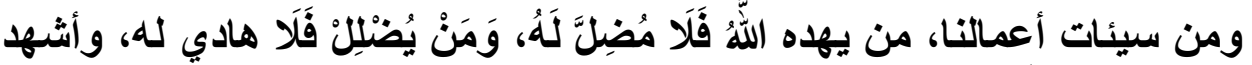

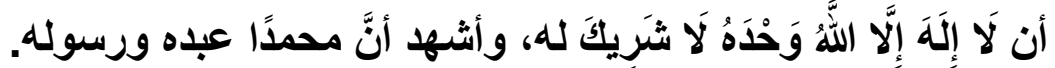

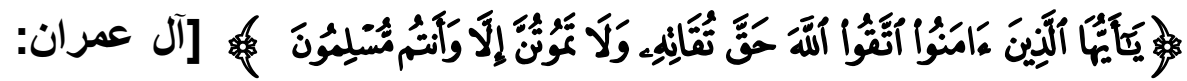

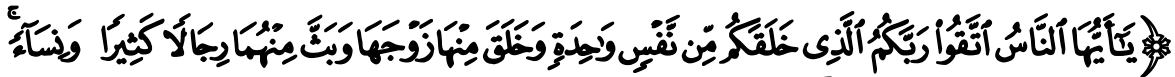

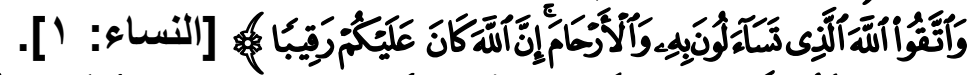

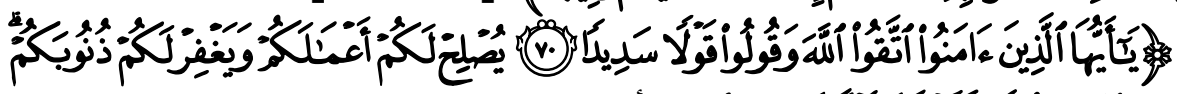

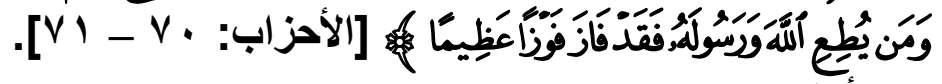
أما بعد: فمع ضعف هذه الأمة المكلومة، وتسلط أعدائها، يخرج من أبناء جلاتها من يطعن في خاصرتها؛ مما يزيد ضعفها، ويفرق جماعتها، من الفرق المبتدعة التي تنتسب للإسلام. وهذه الجماعات والفرق لا تخرج إلا في الفتن والحروب عند أنفصام عقد

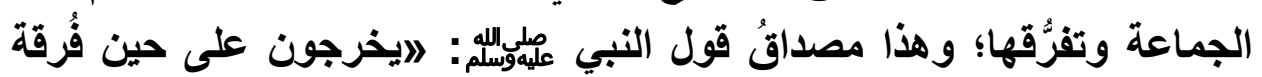
من الناسع) ('). ومن هذه الجماعات التي وُلاتُّ حديثًا ما يسمى بتنظيم 》الاولة الإسلاميةها،

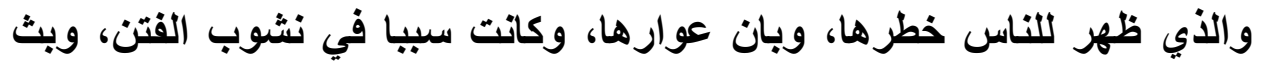
الشبهات بين أفراد الأمة. وتكمنُ خطورة مثل هذه التظيمات بأنها: لا تكتفي بإسقاط المخالفين لها

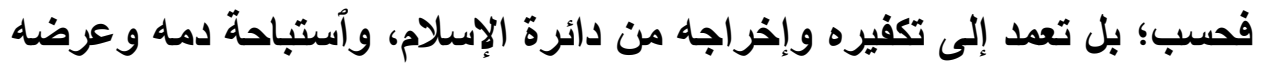

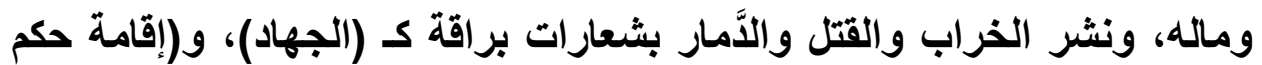

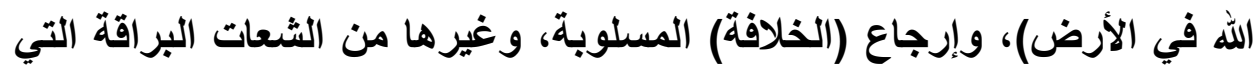

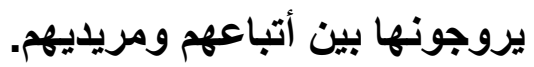

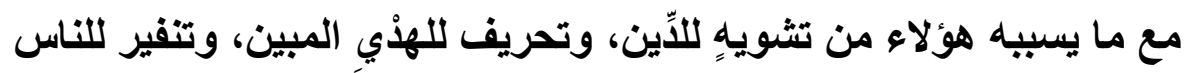

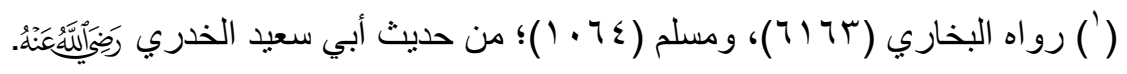
$1 \cdot \mu$ 


$$
\text { عن شريعة سيد المرسلين علمّوسلسله. }
$$

فكانوا والعدو في خندق واحد لحرب الإسلام وأهله، وتثنويه الدين، فوجد

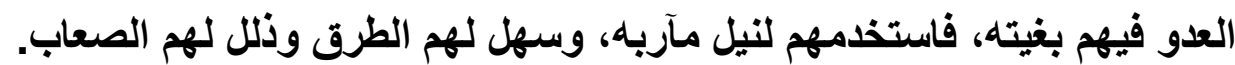

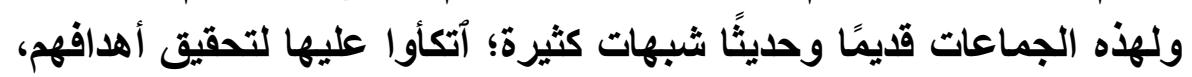

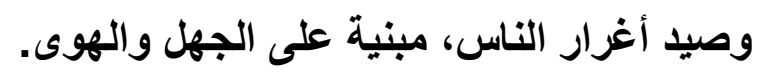

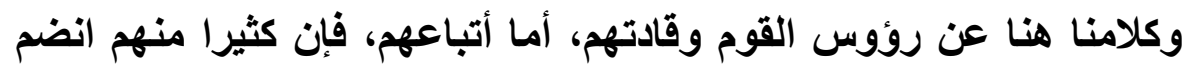

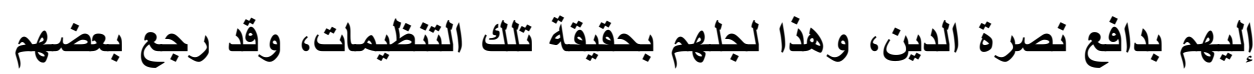

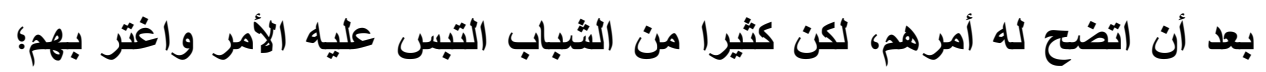

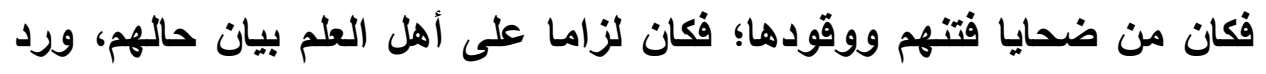
شبهاتهم، حتى يتضح أمرهم. لذا اختار الباحث ـ غفر الله لهه ــ أن يأتي على أبرز هذه الثبها، ويردَّ عليها

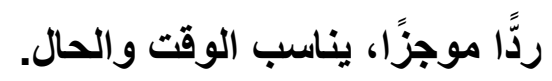

\section{مع أهمية البهث وأسباب افتياره:}

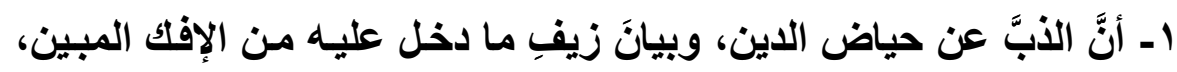

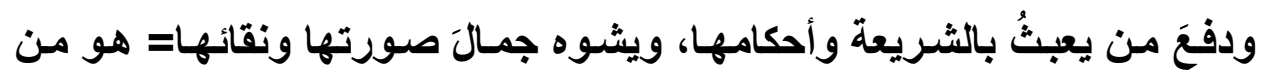

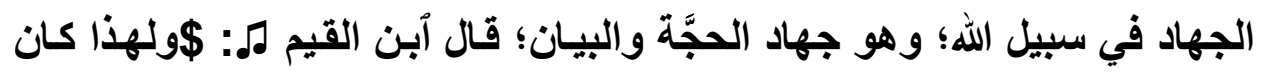

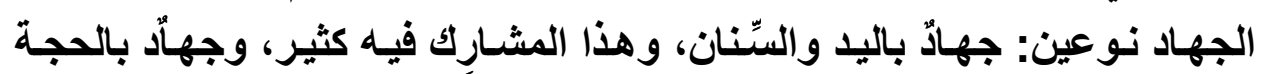

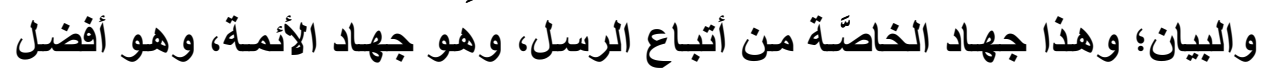

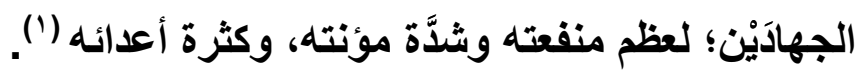

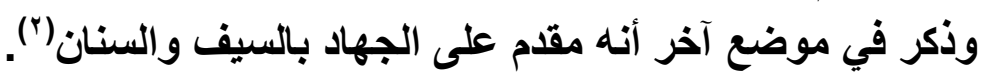

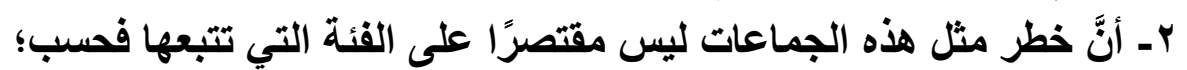

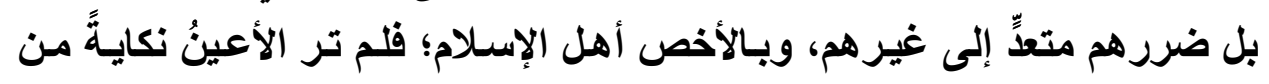

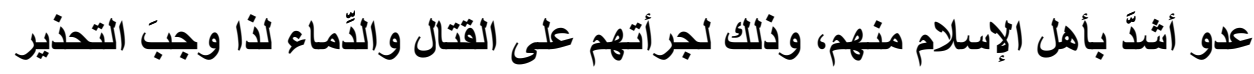
منهم نصحًا للخلق، وبيانًا للحقِّ.

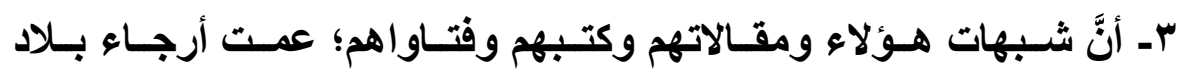

$$
\begin{aligned}
& \text { (") (") مفتاح دار السعادة ( (19/1). } \\
& \text { (') ينظر: الكافية الثافية (ص.'(1).). }
\end{aligned}
$$


المسلمين، وبخاصة مع سهولة أنتشار ها وتيسُر وصولها إلى أيدي النساس، عبر

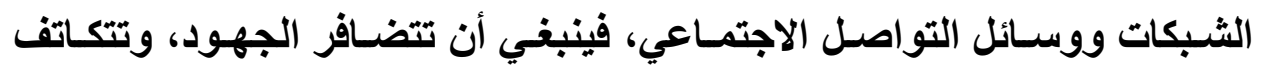

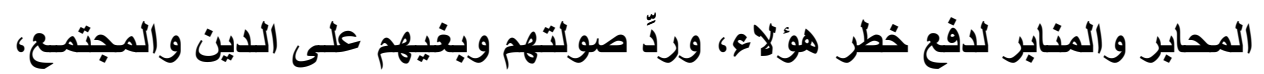

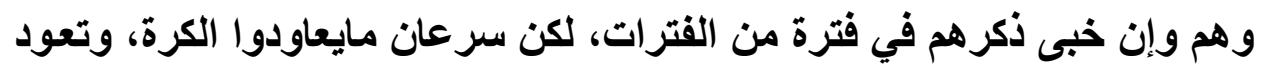

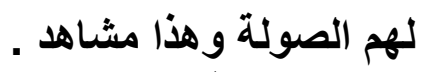

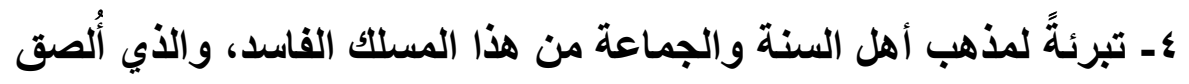

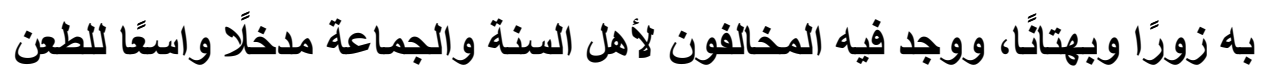
بهم، وتثويه دعوتهم.

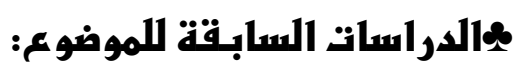
من أبرز الكتب مساسًا بالموضوع - على حد ما وققت عليه - الاراسات التالية: 1- 》اشبهات تنظيم الدولة الإسلامية وأنصاره والرد عليهاه، للاكتور عمـاد

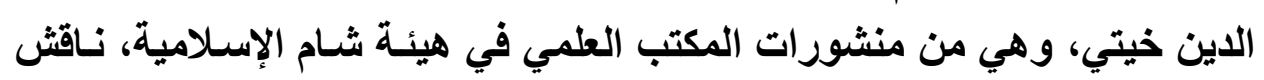
فيها الباحث أبرز الشبهات للدى التظئم، وقد استفدت منهـا في البحث كثيرًا؛ وبخاصة نقله لبعض أقوال وكتابات التنظيم.

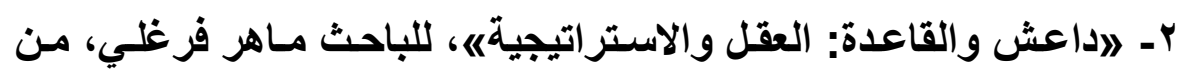

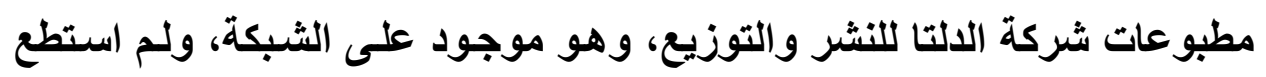
الإفادة منه كونه في مُعرضِ البيع الأكتروني، وليس كاملًا.

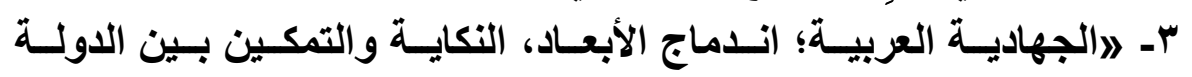

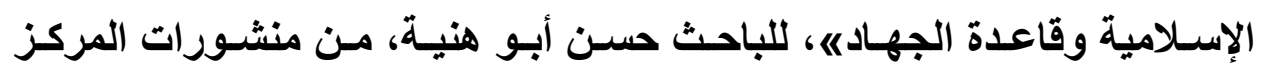
العربي للأبحاث ودراسة السياسيات، وحاله كحال سابقه.

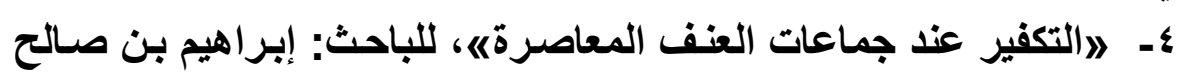

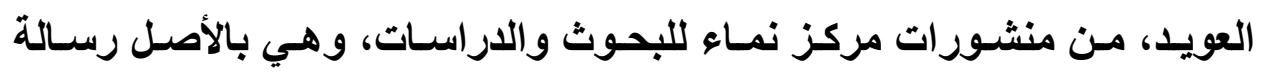

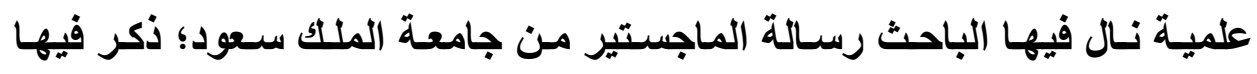
الباحث بعض الثبه المتعلقة بالتكفيز. 


\section{مه فطة البحث:}

يتكون البحث من مقدمة، وتمهيد، ومبحثين، وخاتمة.

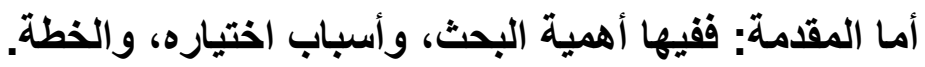
وأما التمهيد: فقيه التعريف بمفردات العنوان، وفيه مطلبه التبان: المطلب الأول: بيان مغنى الثبهة لغة واصنة الفطلاحًا. المطلب الثاني: بيان المراد بالجماعات التكفيرية المعاصرة.

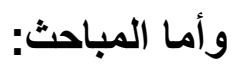
المبحث الأول: الثبه المتعلقة بالجهاد والخلافة.

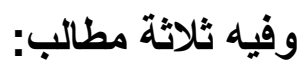

المطلب الأول: شبهة إعلان الخلافة ووجوب اللحاق بها.

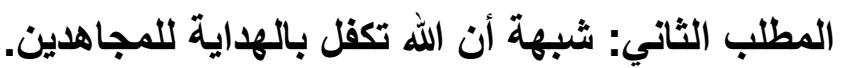

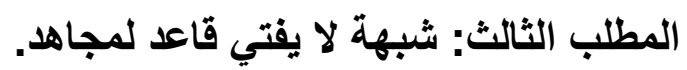
المبحث الثاني: الثبه المتعلقة بالتكفير.

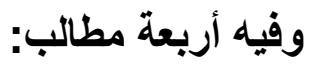
المطلب الأول: شبهة تكفير من لم يحكم بما أنزل الله.

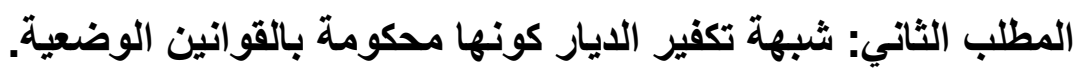
المطلب الثالث: شبهة تكفير من والى الكفار على المسلمين. المطلب الرابع: شبهة تكفير الجيوش في في الدئ الدول الإسلامية. وخاتمة؛ فيها أبرز النتائج، والتوصيات.

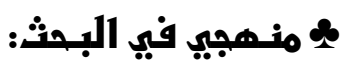

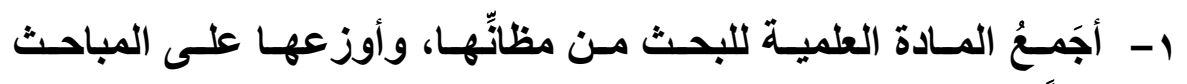
والمطالب وفقًا للخطة. ץ- أعزو الآيات القرآنية الواردة في صلب الرسالة إلى سورها، وأذكر رقم الآية واسم السورة مع كتابتها بالرسم العثماني.

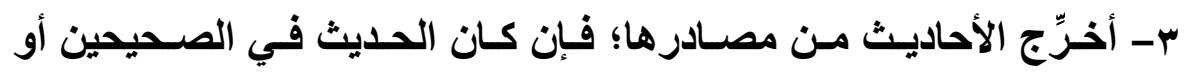

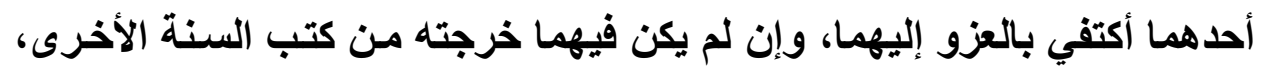
مع ذكر حكم الثيخ الألباني على الحديث. 
جلة كلية الآداب، جامعة سوهاج، العدد السابع والحمسون، الجزء الأول، أكتوبر • Y • Y م

ع - أذكر من شبه التظظيم ما كان خارجًا منـه، ولبَّس فيهـ على أتباعـه؛ ولا

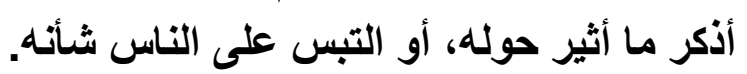

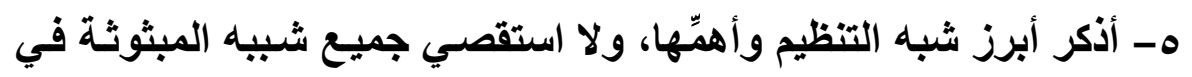
أقواله ومنشور اته؛ إذ تحتاج إلى بسط وسعة وقته، ولا يسعها المقام. 


\section{1 \\ التنعربف بـمصطلهات البهث}

$$
\text { وفيه مطلبان: }
$$

المطلب الأول: بيان معنى الثبهة لغة واصطلاحا.

المطلب الثاني: بيان المراد بالجماعات التكفيرية المعاصرة.

\section{المطلب الأورل \\ بيان معنـى الثبـهة لغة واصطلامًا}

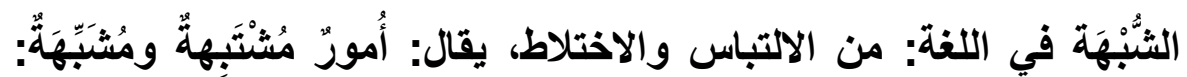

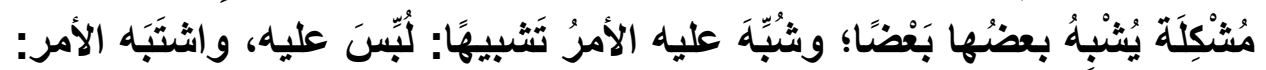

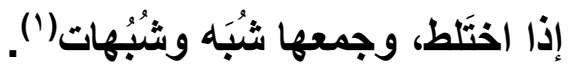

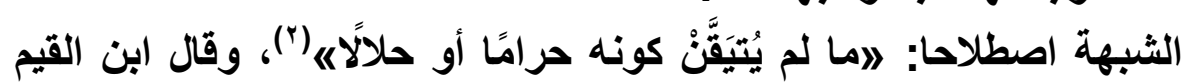

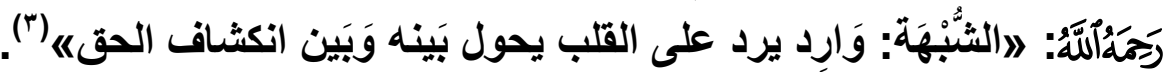
فيكون المراد بالشبهات من خلال ما تقدَّم - والله أعلم -: هي الأمور ولئه

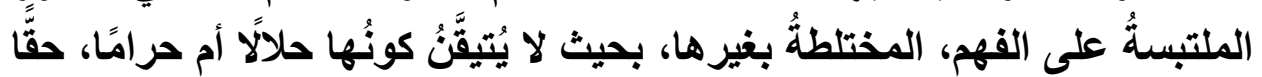
أم باطلًا، خطأً أم صوابًا. وهذا الالتباس يرجع إلى ثلاثة أسباب:

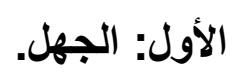
الثاني: التباع الهوى. التول. الثالث: أو سوء في الفهم.

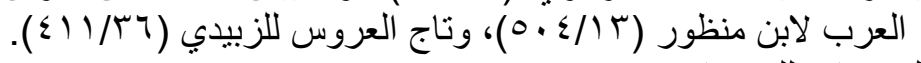


جلة كلية الآداب، جامعة سوهاج، العدد السابع والحمسون، الجزء الأول، أكتوبر • Y • Y م

فإن الثبهة عندما تتمكن من صاحبها؛ فهو إما أن يكون جاهلا ولا يستطيع دفعها، وإما أن يكون ذلك من قبيل الهوى واتباعه، وهذا هنا الأغلب على حال هال أهل البلاع، أو يكون ذلك من باب سوع فهمه في النصوص الثرعية. 


\section{المطلب الثاني \\ بيان المراد بالجما عات التكفيرية المعاصرة}

لبيان المراد من هذا المصطلح؛ لا بد من توضيح كل لفظة من ألفاظه على

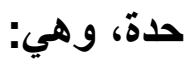

(الجماعات)، (التكفيرية)، (المعاصرة).

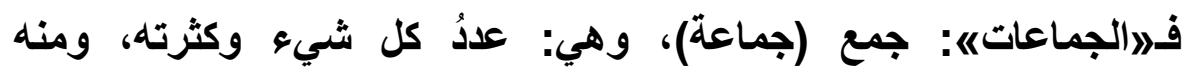

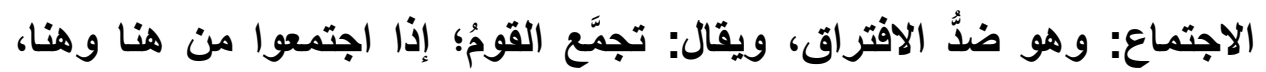

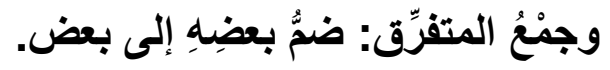
والجماعة إن أريد بها في اللغة جماعة الناس: فهم القوم المجتمعون على

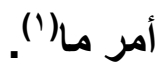

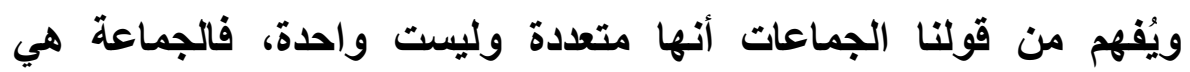

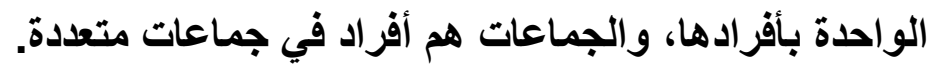
واختلف العلماء في معنى الجماعة التي ورد ذكرهاء فياء في الأحاديث؛ جمعها

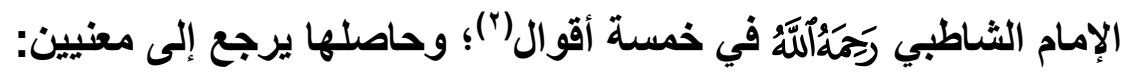

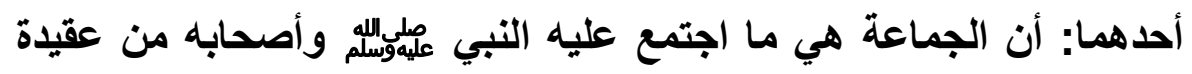

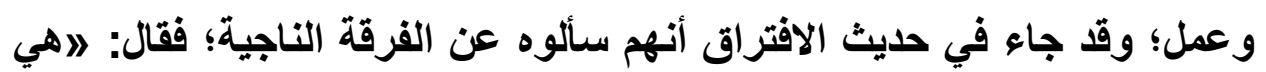

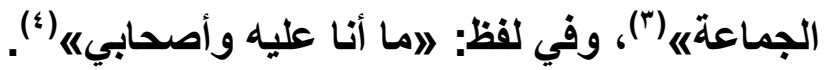

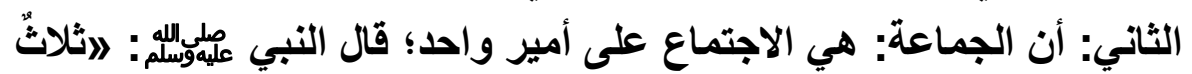

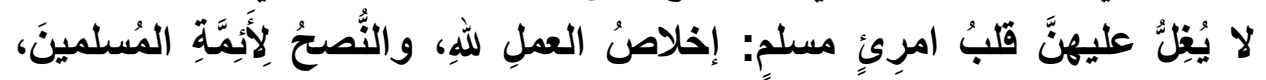

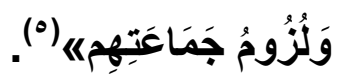

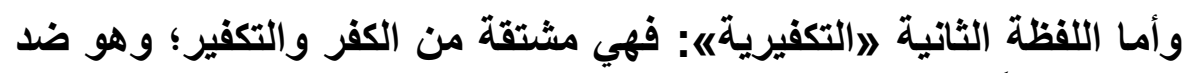

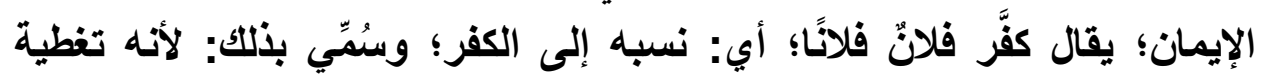

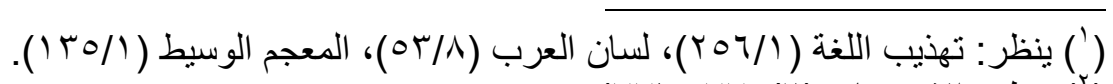

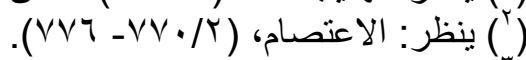

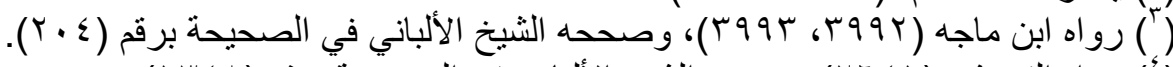

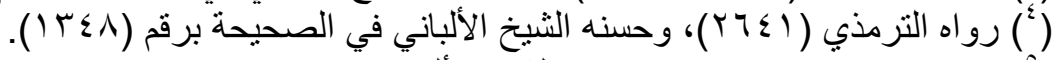

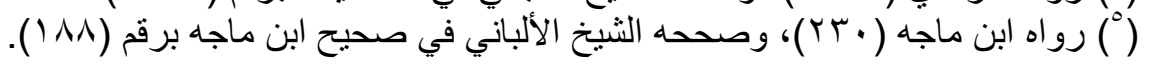

$$
\begin{aligned}
& 11 .
\end{aligned}
$$




\section{للحق، وكفران النعمة: جحودها وسترها'").

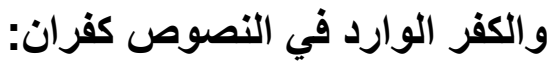

كفر أكبر: وهو الموجب للخلود في النار؛ وهو خمسة أنواع؛ ذكرها ابن

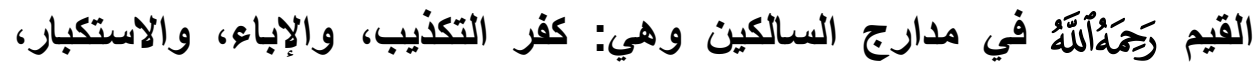
والإعراض، والثك، والنفاق( (r). وكفر أصغر: وهو الموجب لاستحقاق الوعيد دون الخفود.

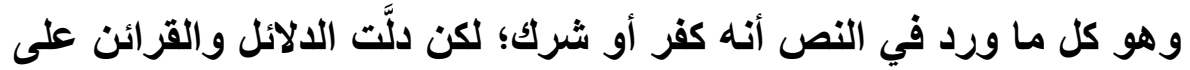
أنه ليس كفرًا أو شركًا، وكذا ما ورد فيه فيه الوعيد بنحو (ليس منا)، أو تبرأ منه أنه

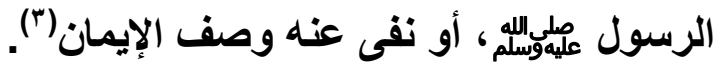
وأما التكفير: لافهو الحكم على أحد من الناس بأنه قد خرجه ون من الإسلام،

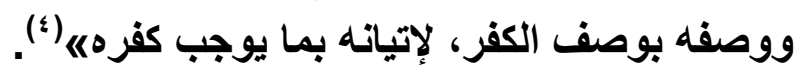
ويتضح مما سبق:

أن التكفيريَّة: نسبة تختصنُ بمن سلتكَ منهج الحكم بالكفر على أعيانٍ، أو

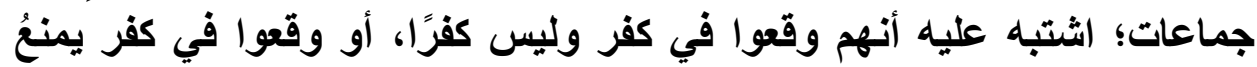
مانعُ من إيقاع الحكم عليهم. وأما اللفظة الثانية لإالمعاصِرةها: فهي: من العصر، وهو: الدهر؛ قال ابن

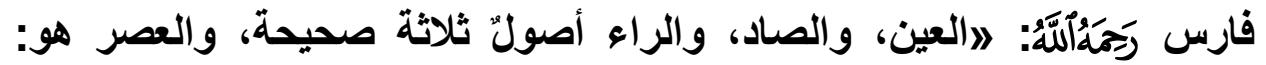

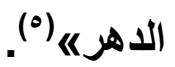
ويأتي من معاني العصر: الزمن الأي ينسب إلى مَلِّك، أو دولة، أو حوادث

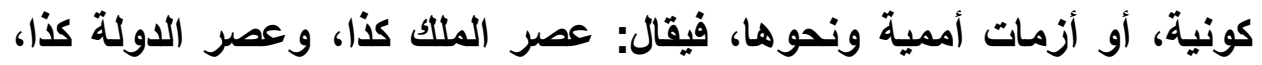

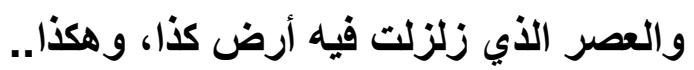
ويأتي أيضًا بمعنى العيش في عصر واحد؛ فيقال: عاصر فلانٌ فلانًا؛ أي:

$$
\begin{aligned}
& \text { (') (') ينظر : مقاييس اللغة (100/0)، ولسان العرب (10 (1) ـ (). } \\
& \text { (rTA_rTV/) ( }
\end{aligned}
$$

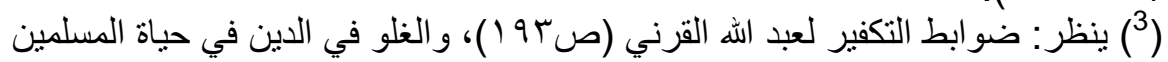

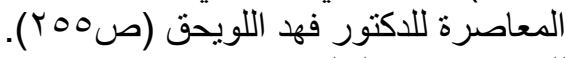

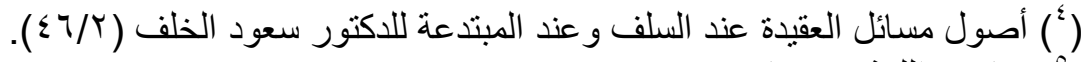

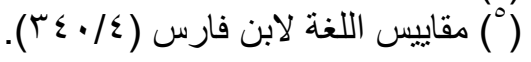




$$
\text { عاشَا في عصر واحد('). }
$$

ف(المعاصرَة)): اجتماع شيئين في عصر واحد، وهي: مفاعلة من العصر.

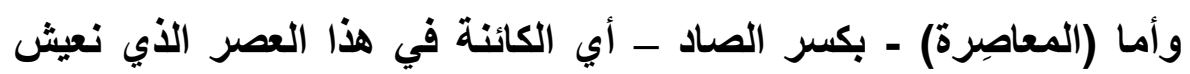
فيه(r)

ويتضح من خلال ما سبق: أن هناتك ثلاثة قيود توضح المراد بالتعريف:

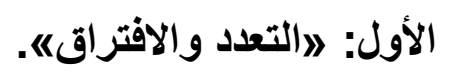

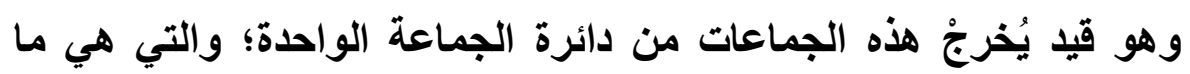

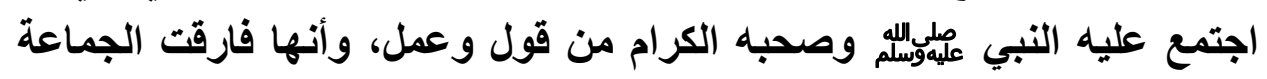

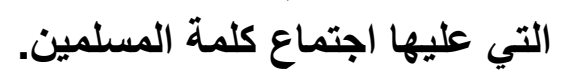

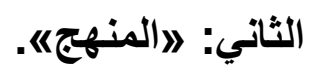
وهو قيد يُخرجها من دائرة منهج أهل السنة والجماعة وطريقتهم في مسائل

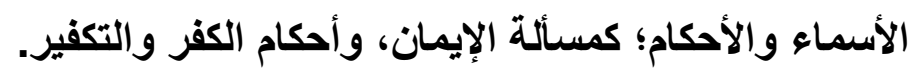

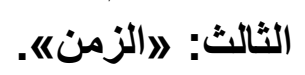

وهو قيا يخرجها من الفِرق والجماعات القديمة، والتي لها نفس الأصول، أو تشاركها في كثير منها.

$$
\text { فيكون المراد بـ (الجماعات التكفيرية المعاصِرة) فئها: }
$$

هي الجماعات التي نشأت في عصرنا هذا، وفارقت جماعة المات المسلمين، بدعوى وقوع بعضها أو جميعها في الكفر والردة، وحاربت على ذلت فئ. 


\section{المبــن الأول}

\section{الثبـ المتعلقةة بالجماد والفلافة.}

$$
\text { وفيه ثلاثة مطالب: }
$$

المطلب الأول: شبهة إعلان الخلافة ووجوب اللحاق بها.

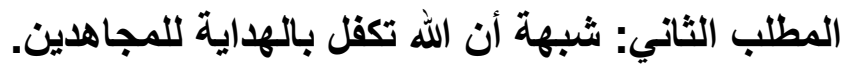
المطلب الثالث: شبهة لا يفتي قاعد لمجاهد.

\section{J11}

\section{شبـهة وجوب الالتماقة بـالفلافة بـعد إعلانـها}

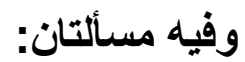
المسألة الأولى: عرضه مسلئن: الثبهة: إن إقامة الخلافة الإسلامية بعد اندثارها منذ سقوط آخر خلافة إسلامية؛ هو

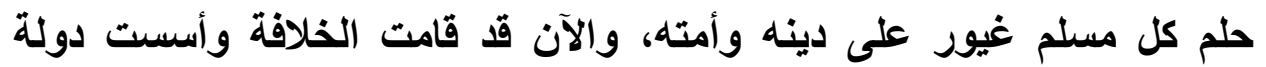

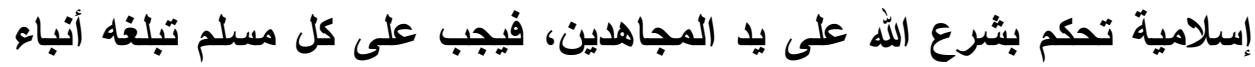

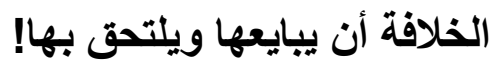

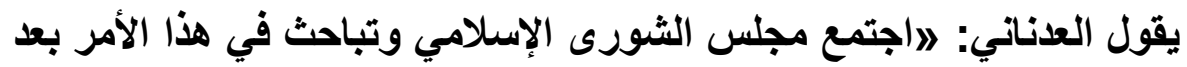

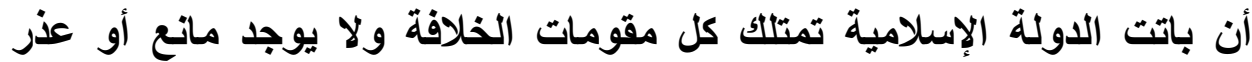

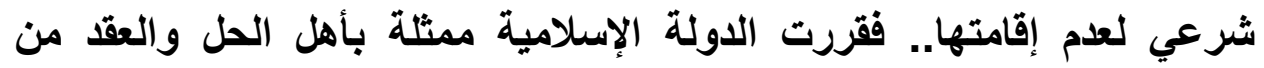
الأعيان والقادة والأمراء ومجلس الثورى، إعلان قيام الخلافة الإسلامية، وتتصيب خليفة للمسلمين، ومبايعة الثيخ المجاهد العالم العامل العابد الإمام

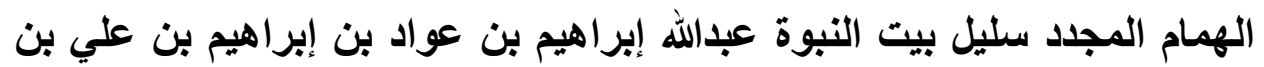

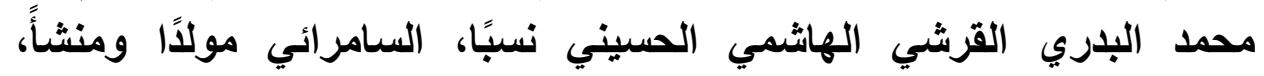
البغدادي طلبًا للعلم وسكنًا، وقد قبل البيعة وبذلك أصبح إمامًا وخليفة للمسلمين

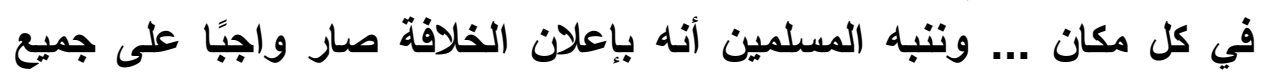


المسلمين مبايعة ونصرة الخليفة حفظه الله وتبطل شرعية جميع الولايات والإمارات والتظيمات التي يتمدد إليها سلطانه ويصل إليها جنده...." (1). المسألة الثانية: الرد على الثبهة: المتحدث باسم التظيم يوجبون على أتباعهم، وعلى جميع المسلمين بعد التئه

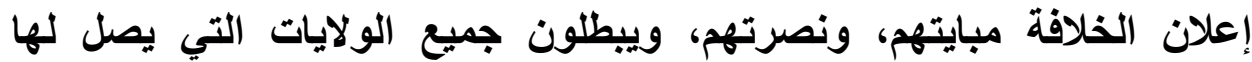
التنظيم (r) (اعلغن

\section{فيرد عليهم من وجوه:}

الأول: أنهم أعلنوا الخلافة، وألزموا جميع المسلمين بمبايعتهم، والحرب قائمة، والعدو لم يدفع بعد، وليس ثمة مقومات لإقامة دولة فضلا عن أن تكون خلافة للمسلمين؟! فالخلافةُ - وما يتبعها من أحكام الإمامة العظمى- تأتي نتيجةً للتمكن في

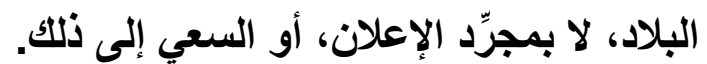

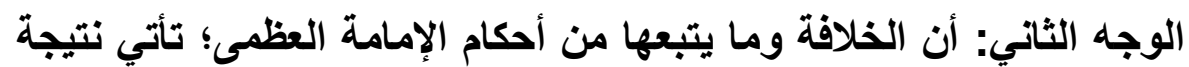
للتمكن في البلاد، لا بمجرد الإعلان، والسعي إلى ذلتك.

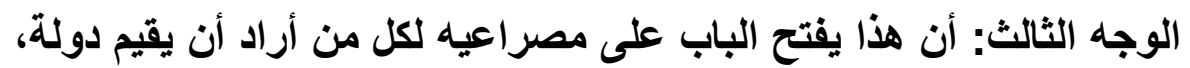
ويعلن عن الخلافة، ويلزم الناس بمبايعته، فإن البيعة كما هو معلوم عند أهل الهل العلم لها شروط وضون عن ابط. الوجه الرابع: أن البيعة خاصة بأهل الحل والقد من العلماء والوجهاء، قال

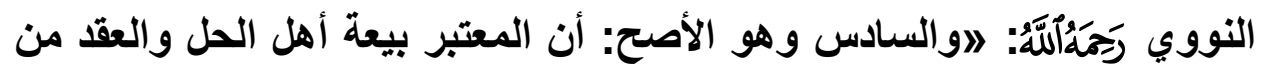

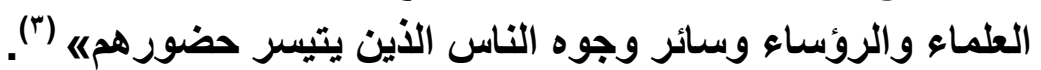

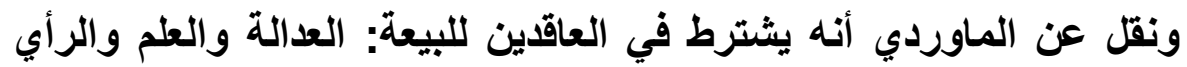

فمن أين لنا معرفة عدالة هؤلاء وعلمهم، وجودة رأيهم، وهم مجهولون عند علماء المسلمين وعامة الناس.

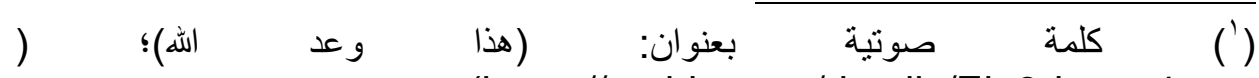

$$
\begin{aligned}
& \text {.).https://archive.org/details/El_3dnany4 }
\end{aligned}
$$

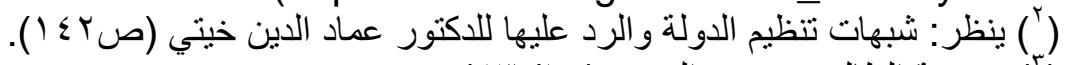

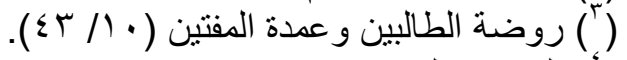

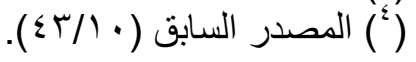




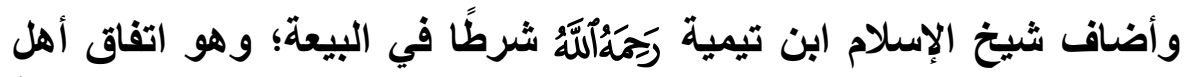

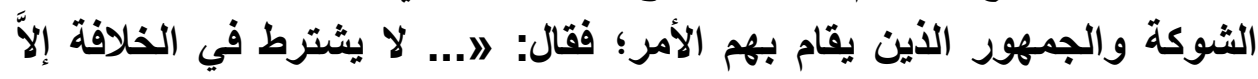

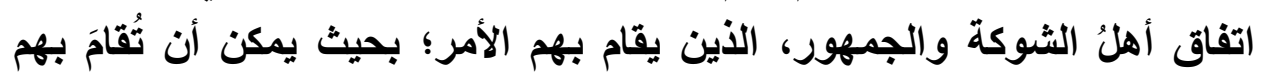

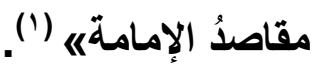

فإذا كان أغلب المسلمين في شتى أقطار الأرض قد رفضوا هذا الدولة من

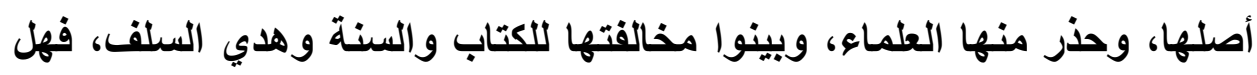
تبقى قيمة معتبرة لهؤلاء الذين عقدوا البيعة والخلافة وبايعوا هذا ولفا الخليفة

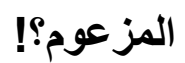

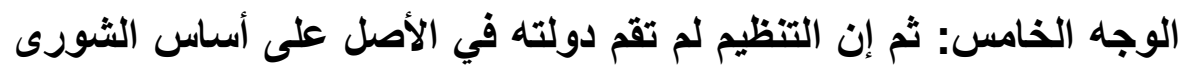

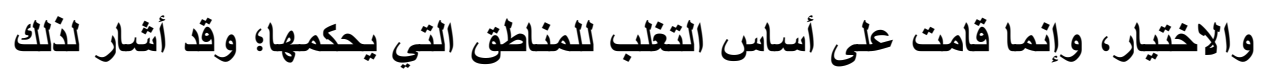

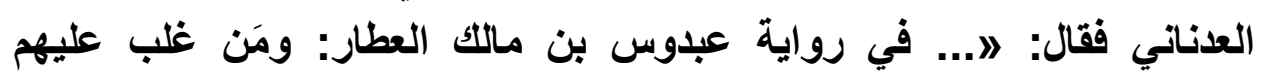

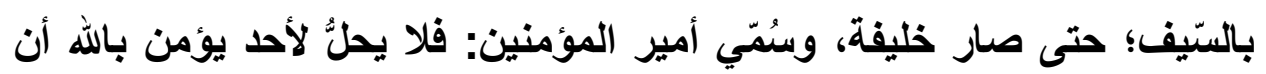

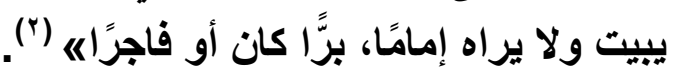

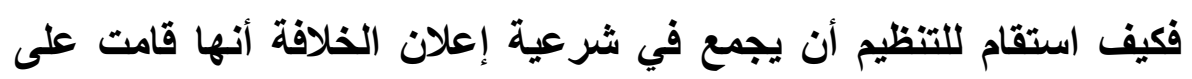

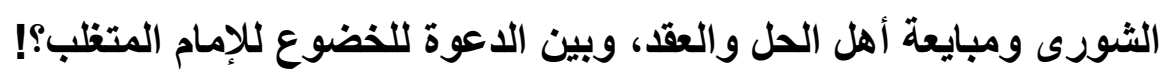

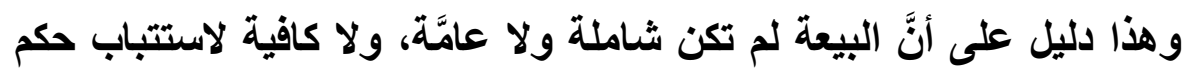

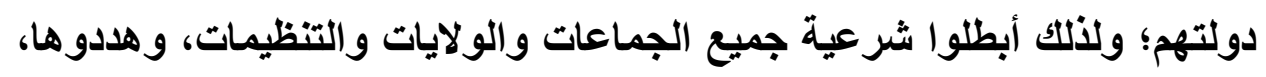

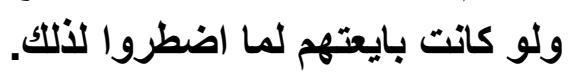

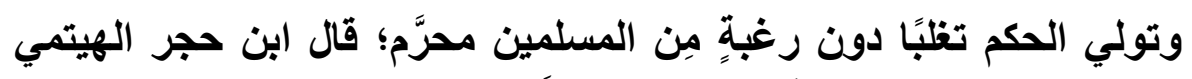

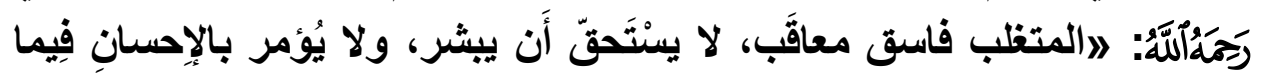

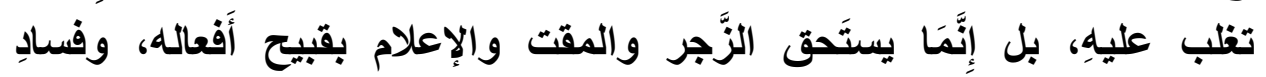
أَحوالهه ("اله

وكذلك الجويني (؛) (2)

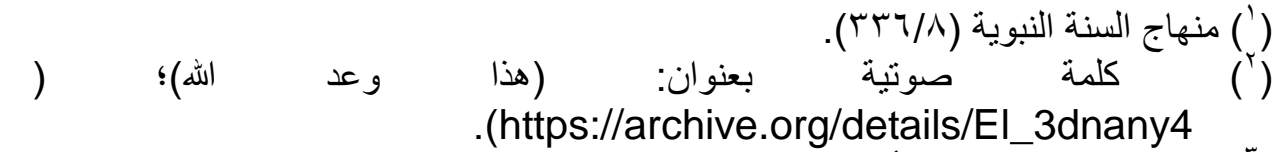

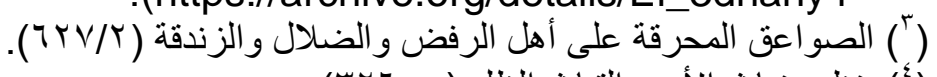

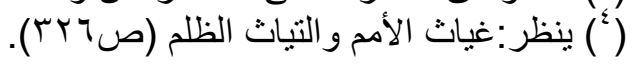


وإنّمَا أجاز أهل العلم ولايةً المتغلب في حال الضرورة، لا الاختيار؛ تغليًا للمصلحة العامة، وبشروطٍ عديدة. ذكرها الماوردي، من حفظ منصب الإمامة، وظهور الطاعة الدينية التي يزول ولئل

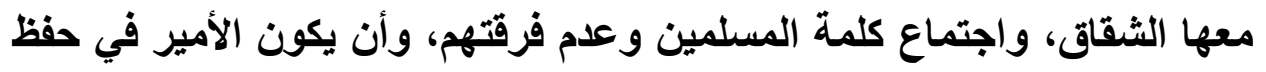

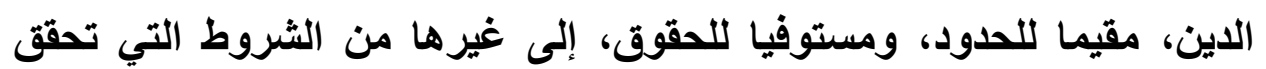
المصلحة في تتصيبه والرضا باه، وطاعته (').

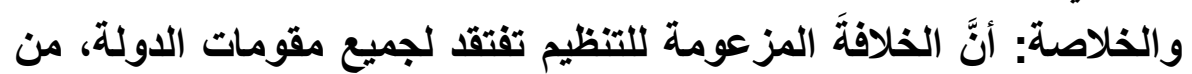

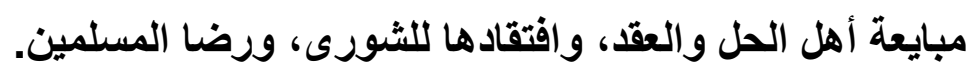


المطلب النانبي

شبـهة أز الله تكهل بالهداية المجاهدين

وفيه مسألتان:

المسألة الأولى: عرضه ملئن: الثبهة:

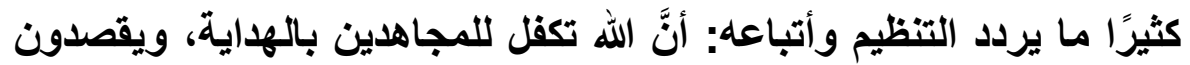

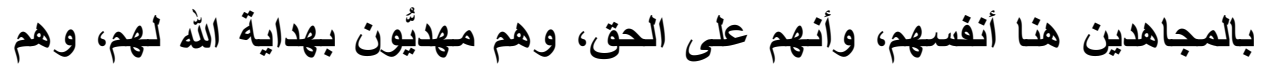

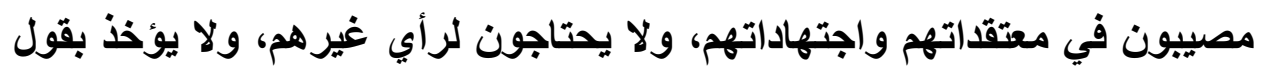
مخالقيهم.

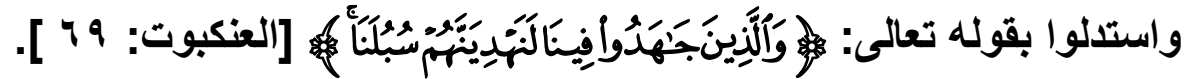

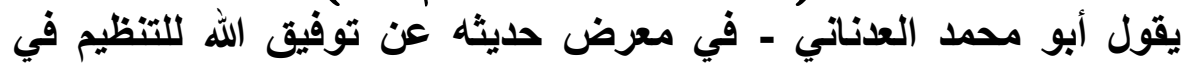

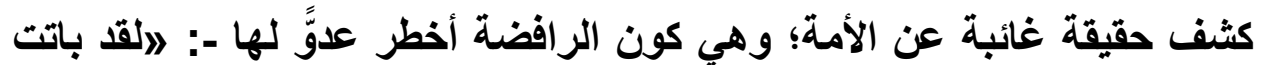

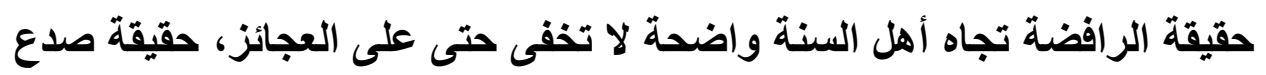

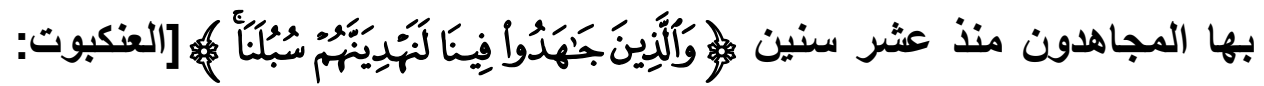

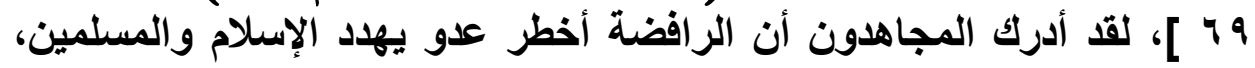

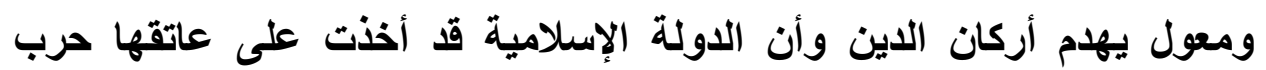

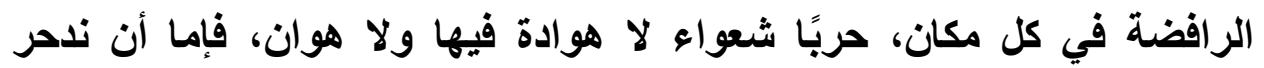

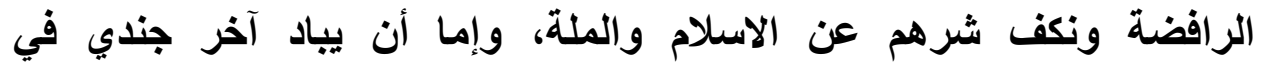

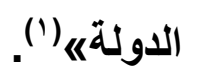

المسألة الثانية: الرد على الثبهة:

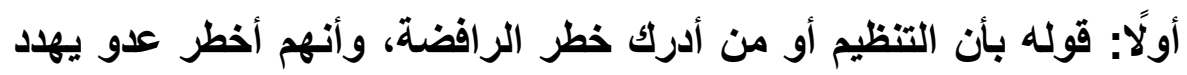

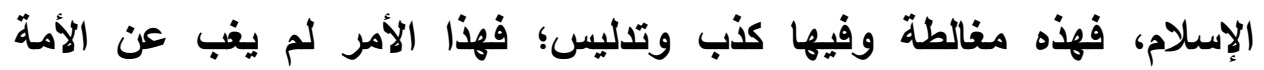

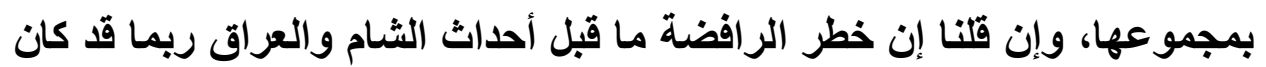

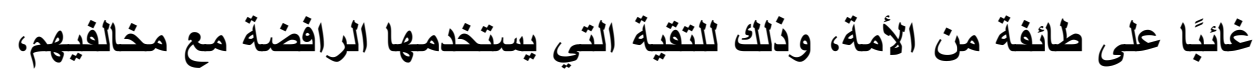

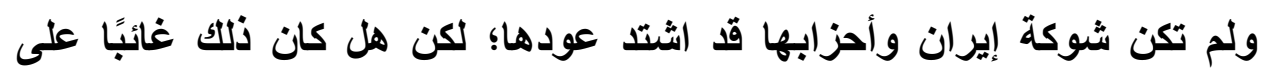

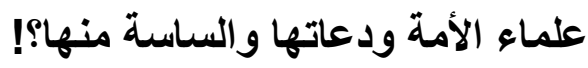

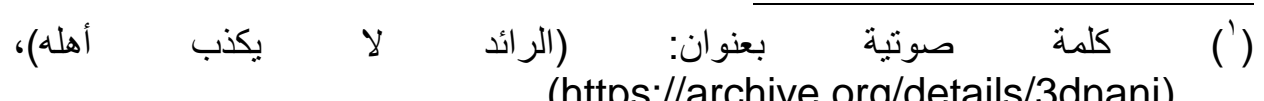
.(https://archive.org/details/3dnani) 


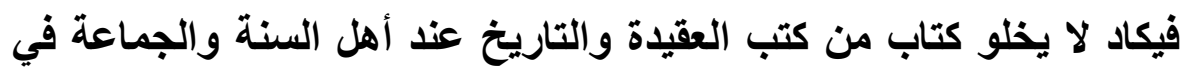

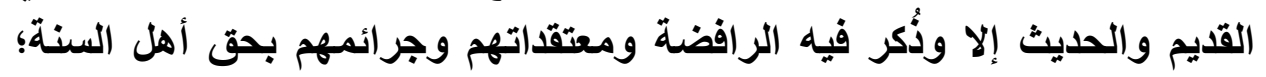

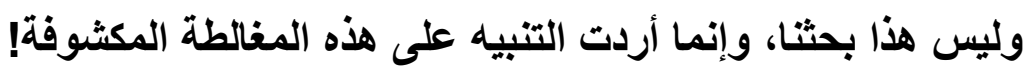

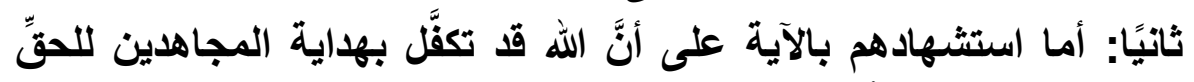

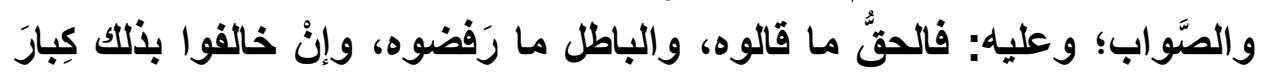

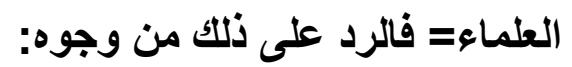

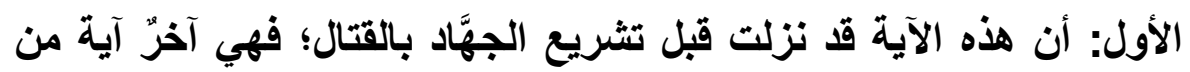

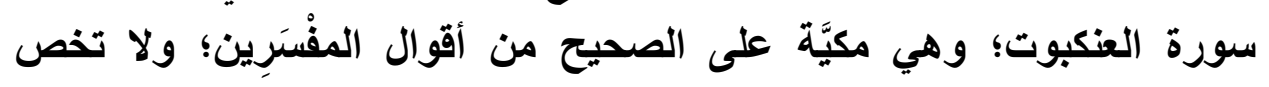

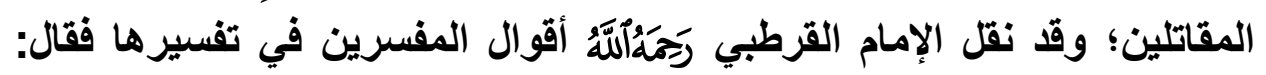

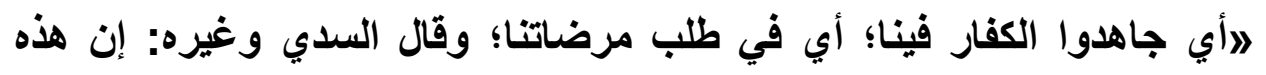

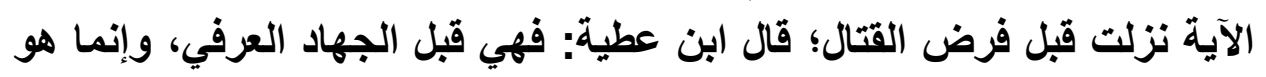

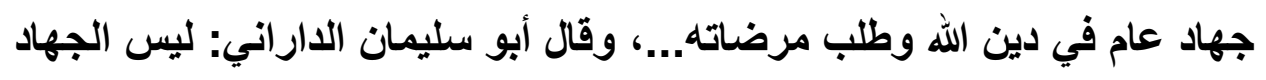

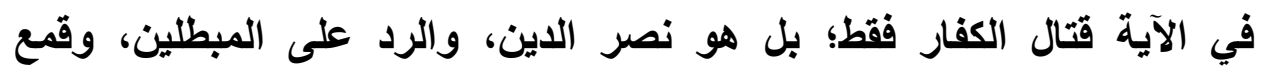

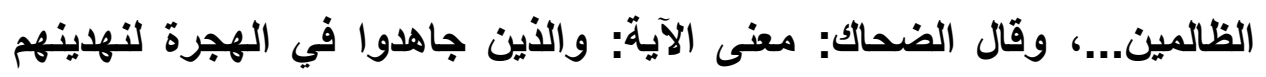

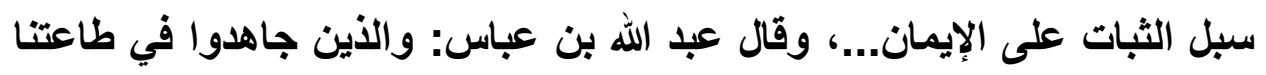

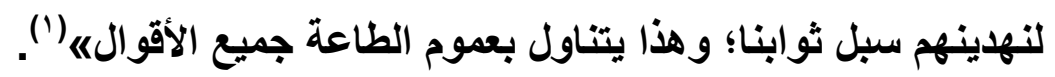

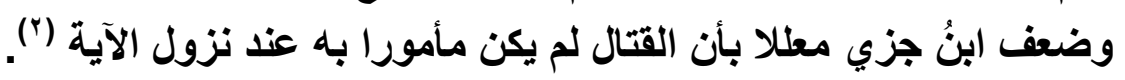

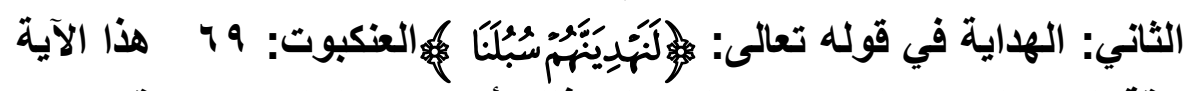

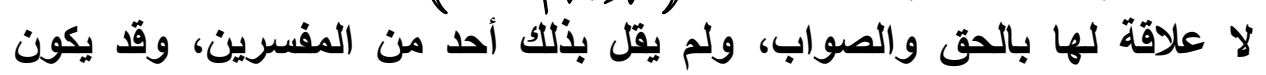

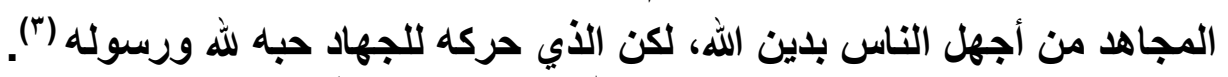

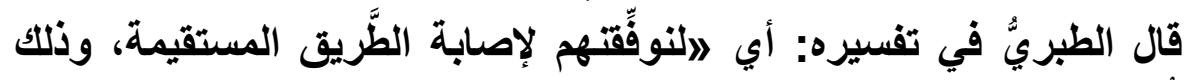

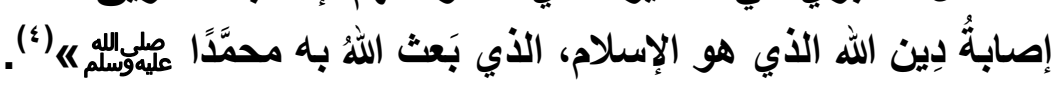

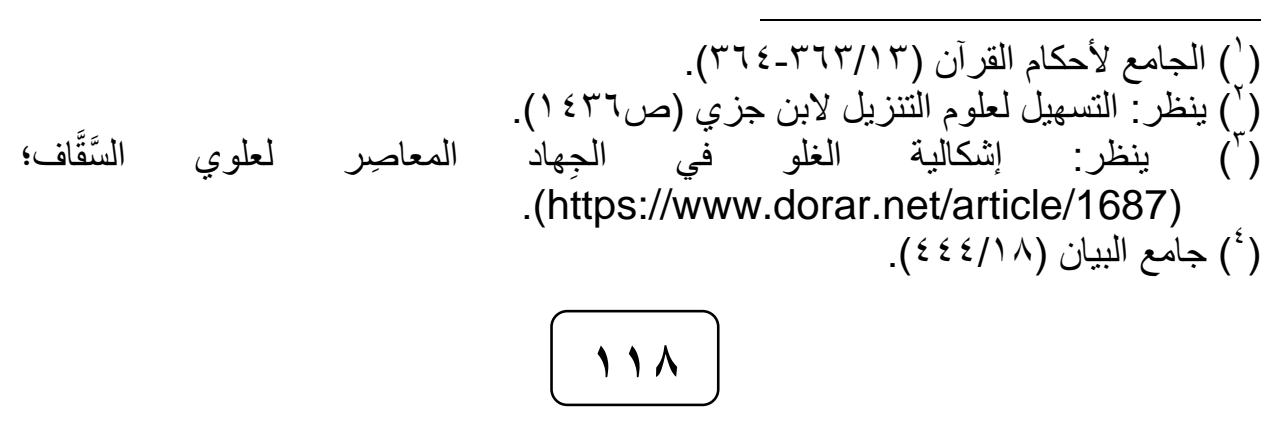




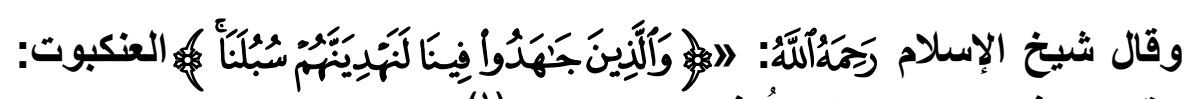

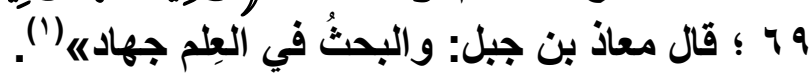

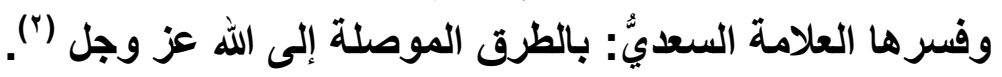

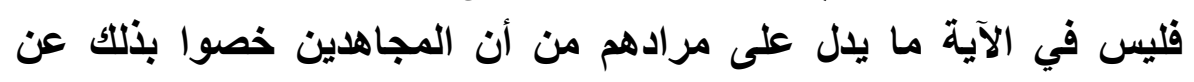

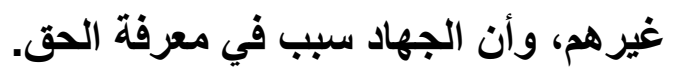

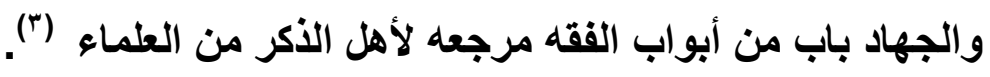

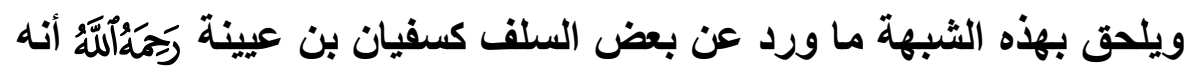

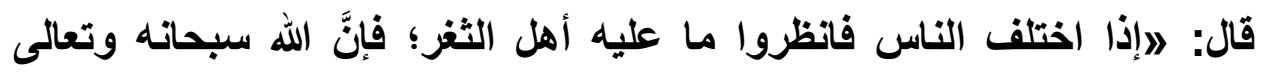

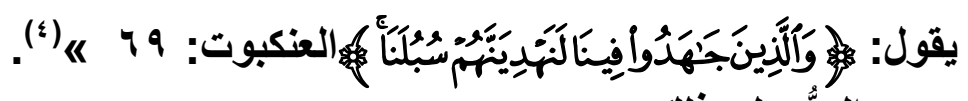

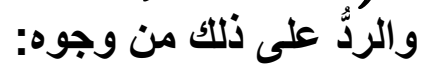

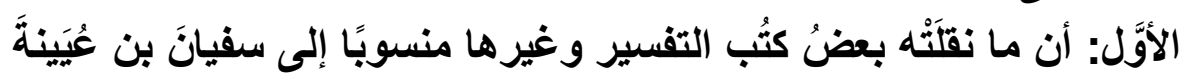
كلها وردت بأسانيا ضعيفة (ن)

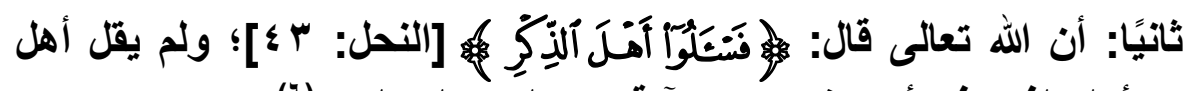

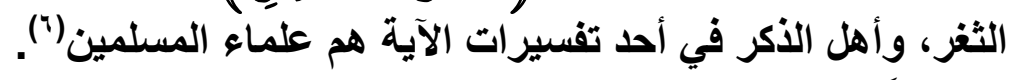

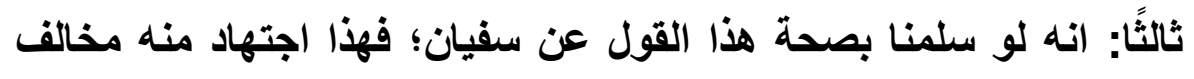
لما فسره العلماء (v)

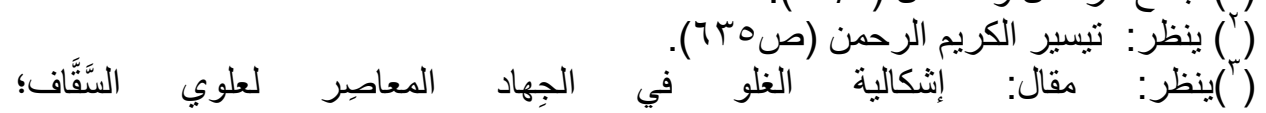
. (https://www.dorar.net/article/1687)

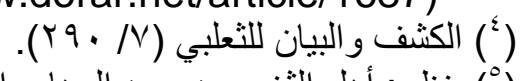

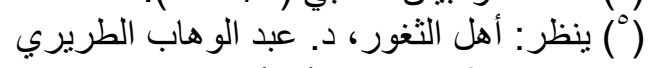
(http://magazine.islamtoday.net/m/art.aspx?ID=456)

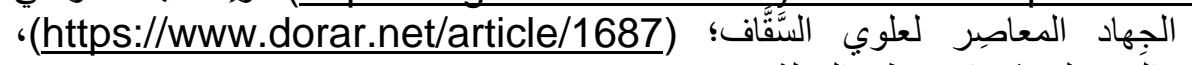

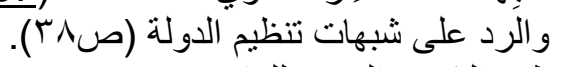

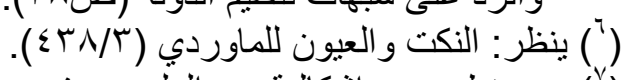

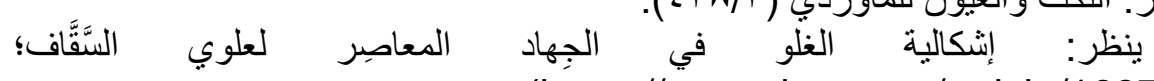
.https://www.dorar.net/article/1687) 
رابعًا: وعلى فرض ثبوت هذا الأثر عن سفيان وغيره؛ فإن المراد به تفضيل

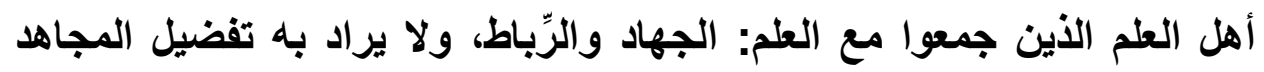
غير العالم على العالم (').

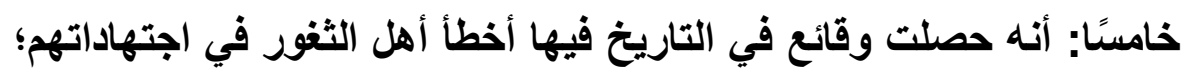

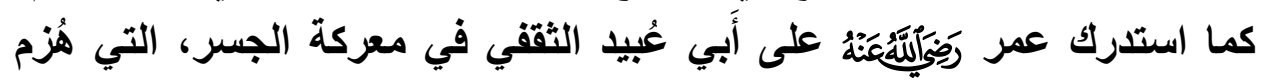

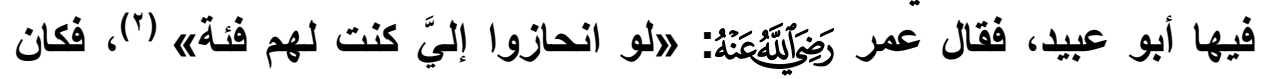

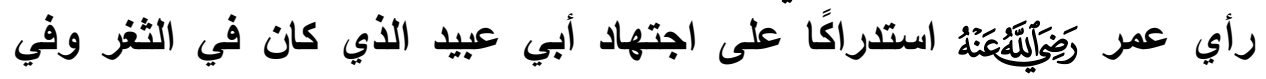
مواجهة الفرس (").

سادسًا: أن الهداية تكون لمن جاهد في سبيل الله حقا وصدقا، لا لـاية معائة معينة

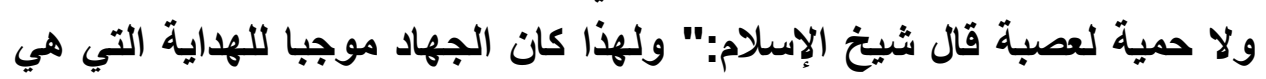

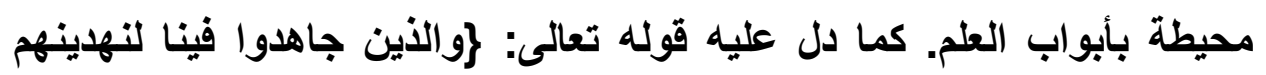

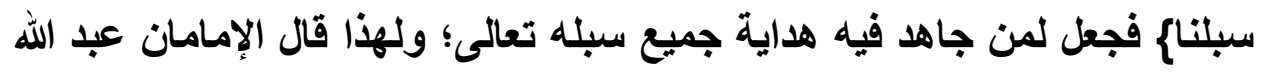

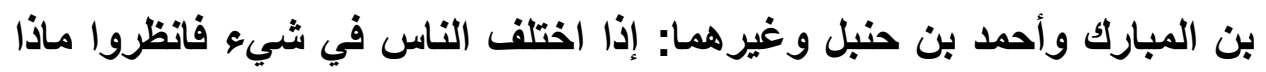

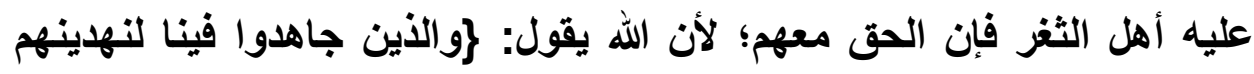

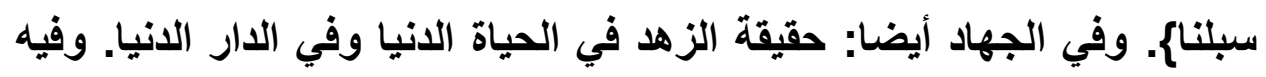

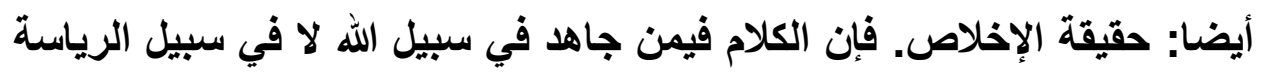

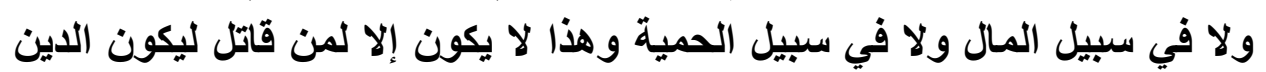

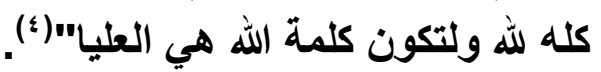

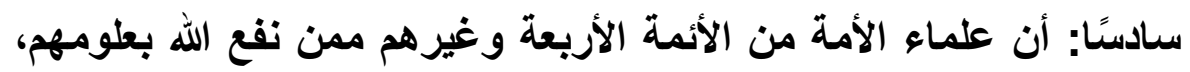

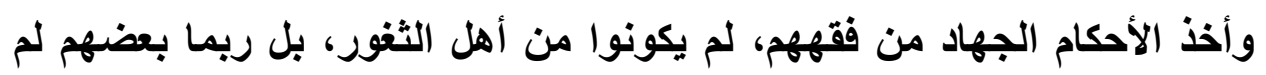

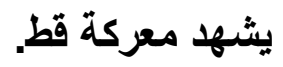

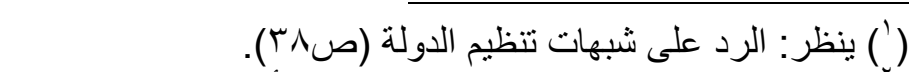

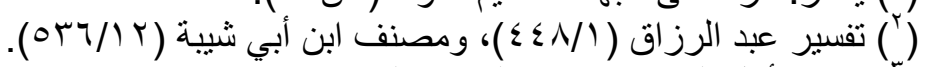

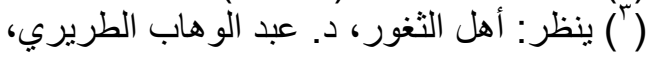

.(http://magazine.islamtoday.net/m/art.aspx?ID=456)

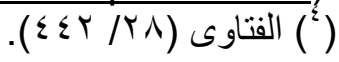

.(http://magazine. islamtoday.net/m/art.aspx?ID=456)

$1 \%$. 
مجلة كلية الآداب، جامعة سوهاج، العدد السابع والحمسون، الجزء الأول، أكتوبر • • † م

قال الإمام مالك لعبد الله العمري: وما أظن ما أنا فيه بدون ما أنت فيه،

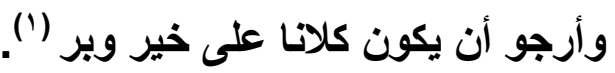

والخلاصة: أن الجهاد له صور لا ينحصر بقتال الأعداء فقط؛ بل يدخل فيه

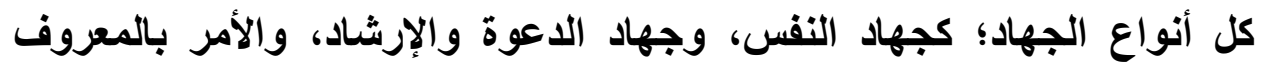

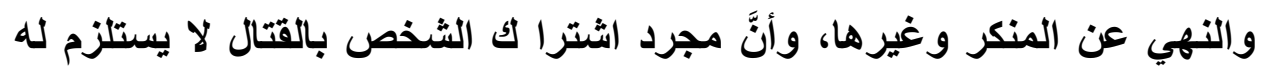

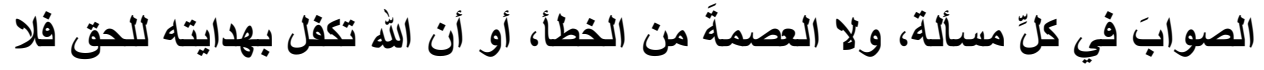

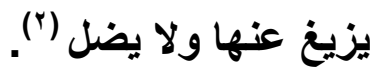

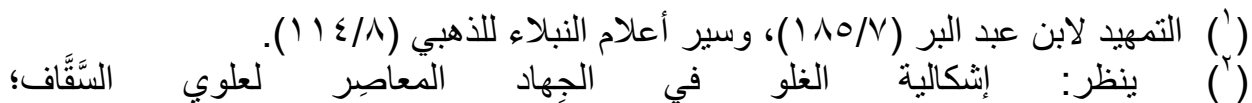

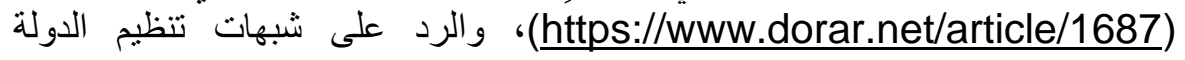




\section{المطلب الثالث}

شبهة لا يفتير قاعد لمجاهد الفالف

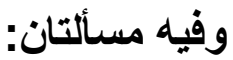

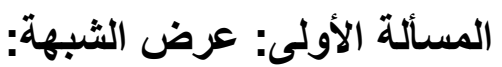

لم أجد على - حد بحثي - تصريحًا للتنظيم يورد فيه هذه العئ العبارة؛ لكنها

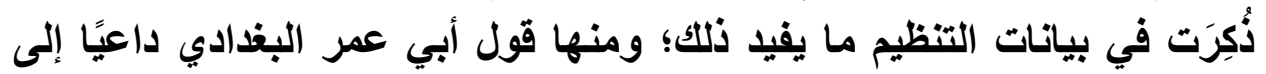

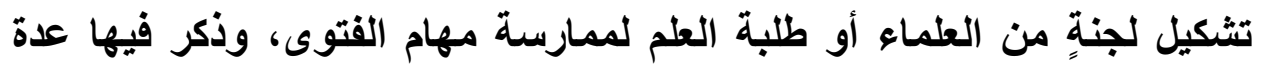

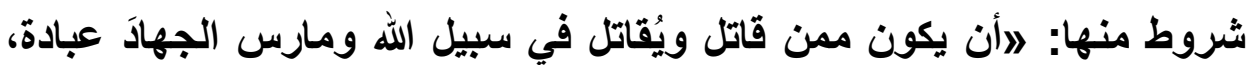

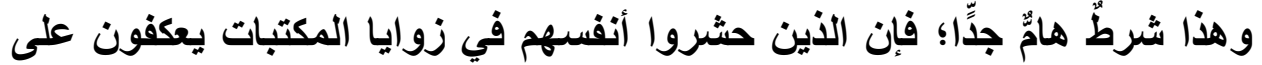

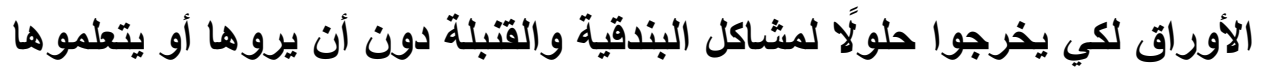

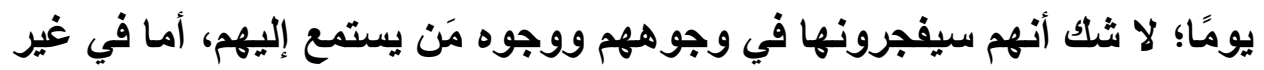

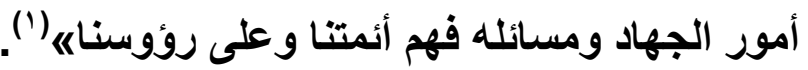
واشترط أيضًا: لاأن يكون مرضيًّا عليه من جميع الفرقاء أو أغلبهم، وليس الفيس

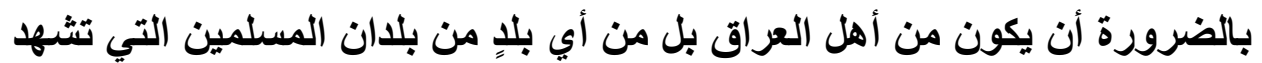

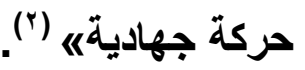

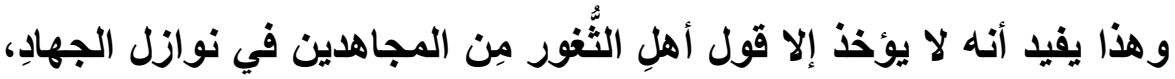

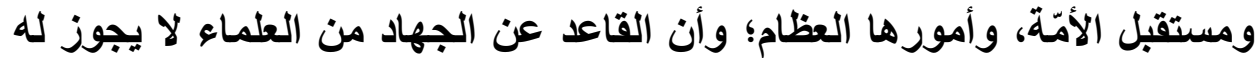
أن يفتي في الجهاد، وليس جديرًا بالسماع لها له.

المسألة الثانية: الرد على الثبهة: هذه المقولة ليس لها مستثد شرعي من القرآن والسنة، ولم يقل بها المها أحد من أهل العلم؛ فضلال على أن تكون مقياسا لمعرفة الحق والباطل.

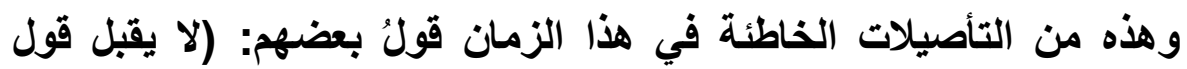

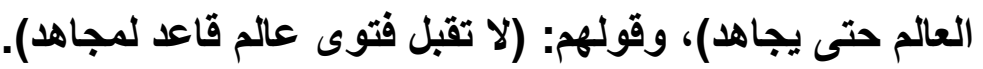


وهذا لا شك تأصيل خاطئ لا أصل له في الشريعة، ولم يظهر إلا في هذا

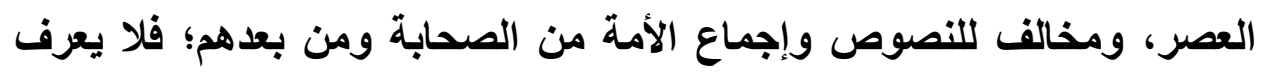

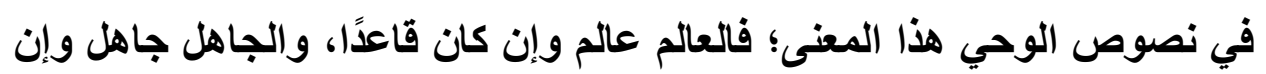

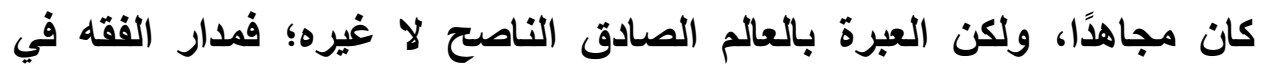

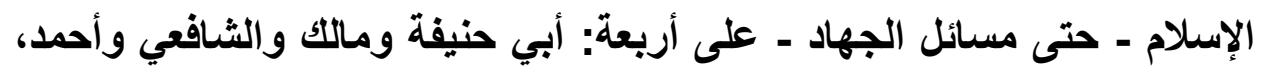

وقد ذكر أهل العلم شروطًا للمفتي في كتبهم؛ منها:

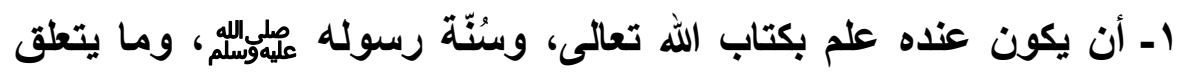
بهما مِن علومِ r- أن يكِون عنده علم علم بمواطن الإجماع والخلاف والمذاهب والآراء الفقهبة. r- أن يكون ملمَّا بأصول الفقه ومبادئه وقواعده، ومقاصد الثُّريعة، فئه

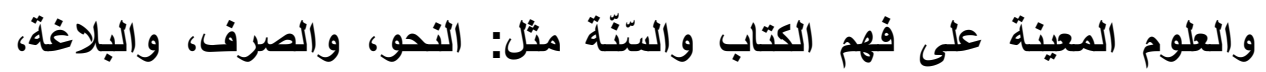
و واللغة، وغيرها.

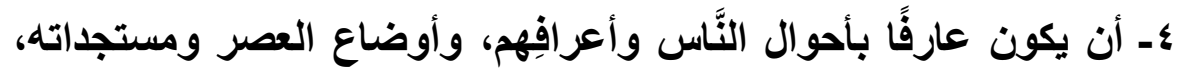

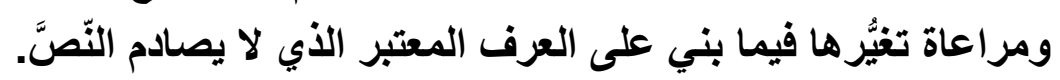

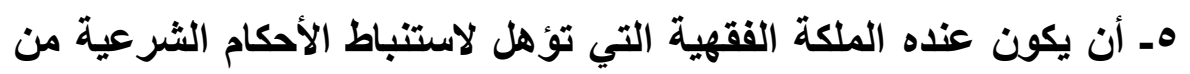
النصوص. ד- أن يكون عنده إلمام بالعربية وقواعدها، ومعاني الألفاظ ومفرداتها؛ كون

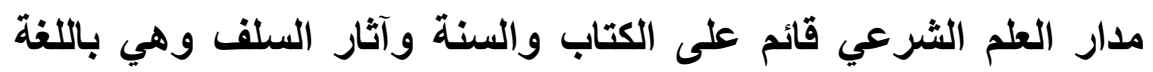

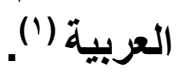

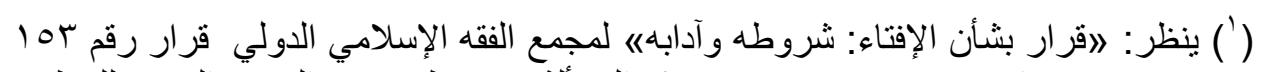
(IV/r)

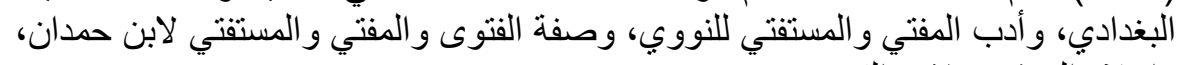
وإعلام الموقعين لابن القيم. 


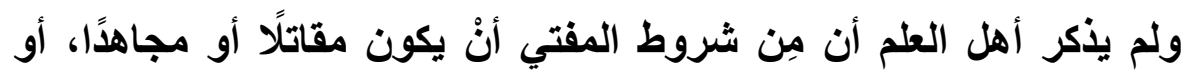

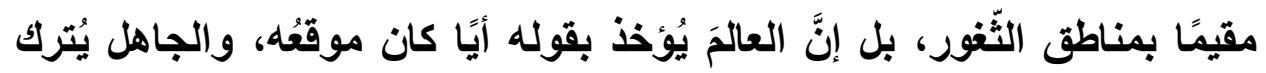

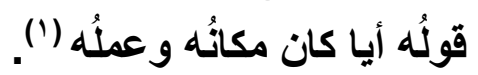

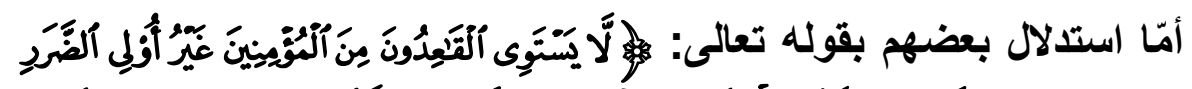

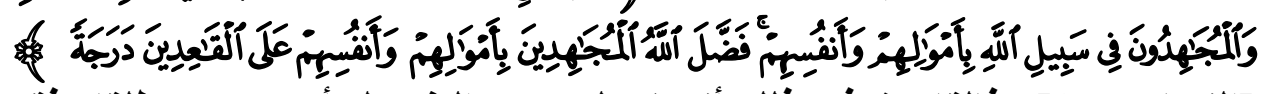

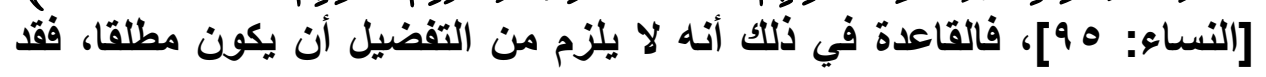
يكون لأسباب منها الحث والترغيب فيله.

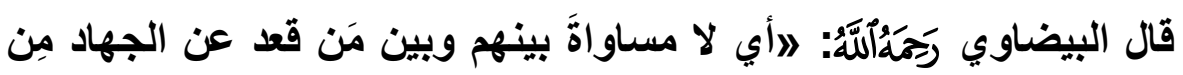

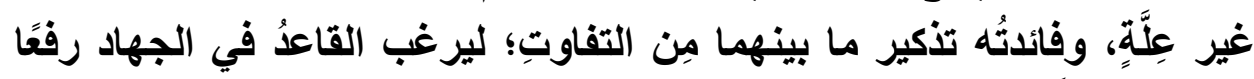

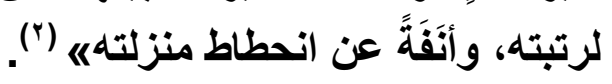

على أن الاشتغال بالطلم، وتعليم الناس دينهم، ونصرة المجاهدين باللسان،

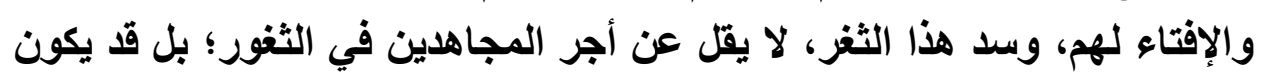

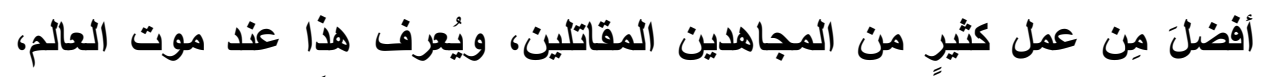

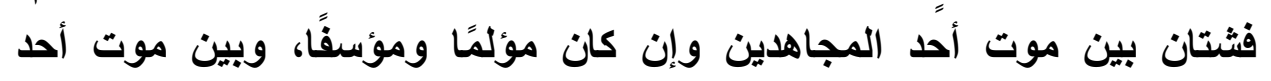
العلماء؛ وما تخسره الأمة بموته.

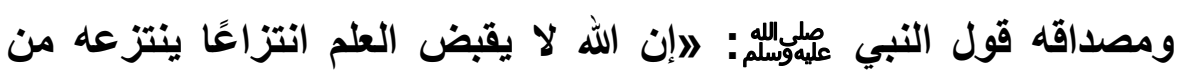

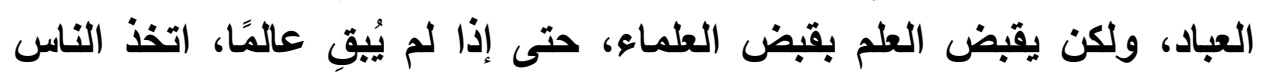

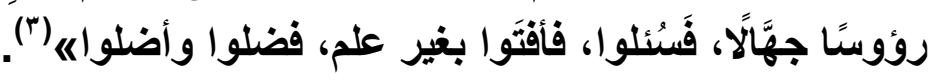

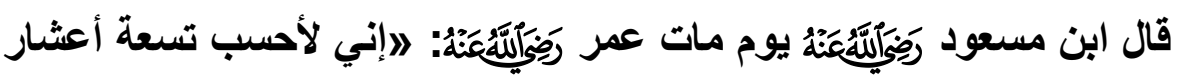

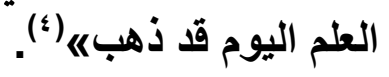

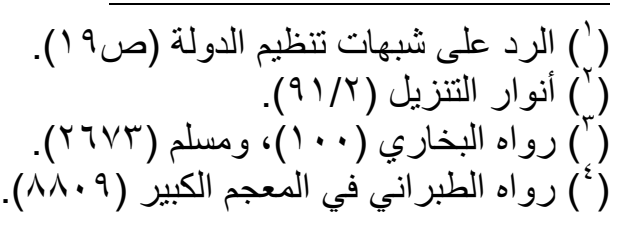


وقيل لسعيد بن جبير رَمَمَهُأَلَهة: لايا أبا عبد الله، ما علامة هلاكَ الناس؟ قال:

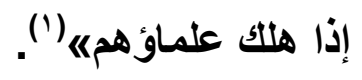

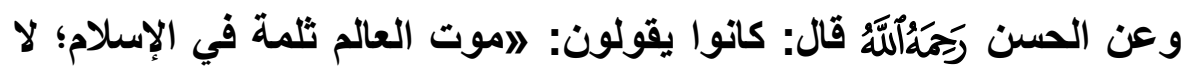

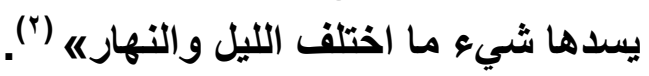

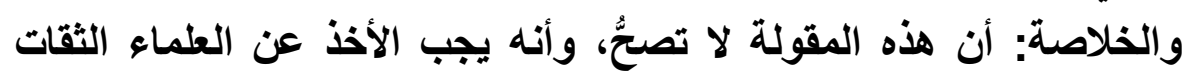

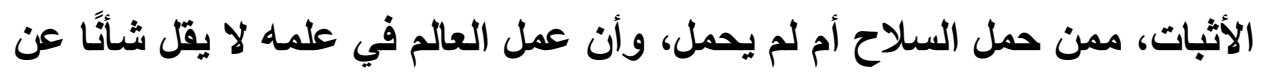

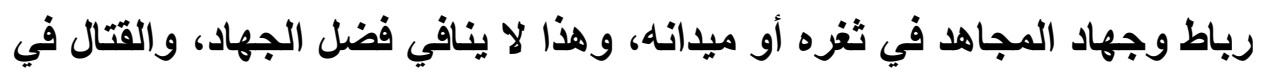
سبيل الله، وأنه من أفضل القربات، وأعلى المقامات. 


\section{المبــث الثنانيي \\ الثببه المتنعلقة بالتنكهبر}

وفيه أربعة مطالب:

المطلب الأول: شبهة مبطه تكفير من لم يحكم بما أنزل الله.

المطلب الثاني: شبهة تكفير الايار كونها محكومة بالقوانين الوضعية. المطلب الثالث: شبهة تكفير من والى الكفار على المسلمين. المطلب الرابع: شبهة تكفير الجيوش في الدول الإسلامية.

\section{المهاب الآول

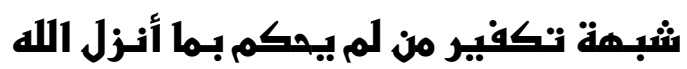

وفيه مسألتان:

المسألة الأولى: عرضه الثبانة:

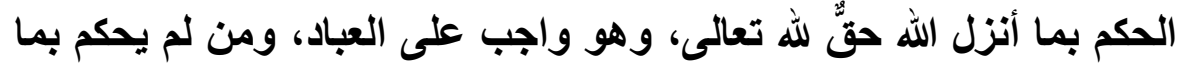

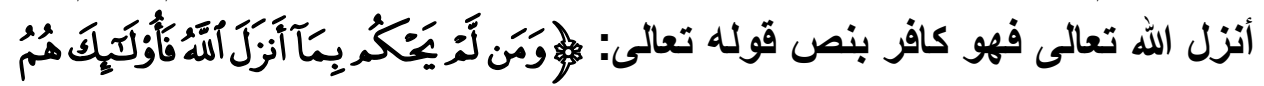

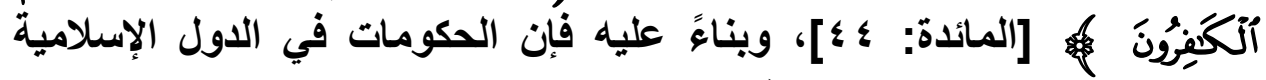
كافرة؛ لأنها لا تحكم بما أنزل الله.

يقول أبو عمر البغدادي: لافهذه بعضنُ ثوابتنا... خامسًا: نرى وجوب الهاب التحاكم إلى شرع الله من خلال الترافع إلى المحاكم الثرعية في الدولة الدئة

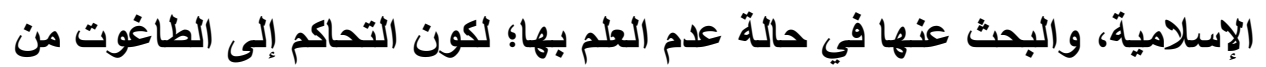

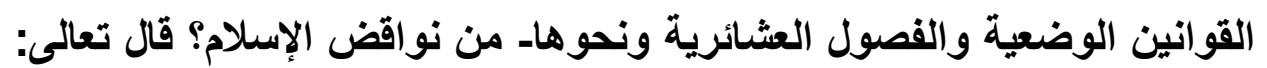

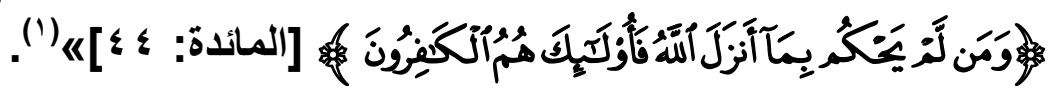

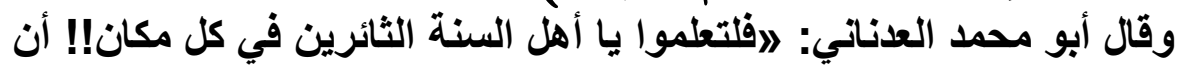

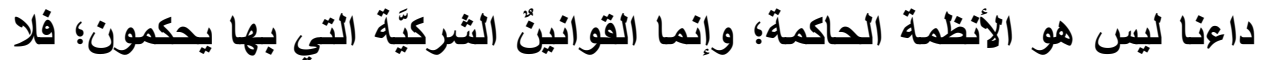
فرق بين حاكم وحاكم مالم نغير الحكم، لا فرق بين مبارك ومعمر وابن على لئ،

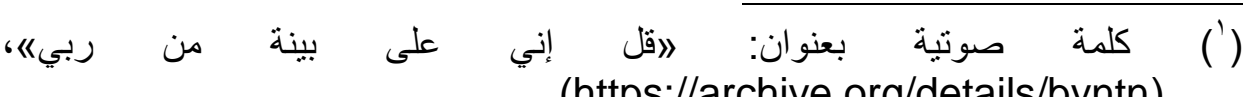
.(https://archive.org/details/byntn) 
وبين مرسي وعبد الجليل والغتوشي؛ فكلهم طواغيت يحكمون نفس القوانين... فعلينا نبذ القوانين الوضعية الشركية، وتحكيم شرع الله؛ ولا سبيل إلى ذلك إلال بالجهاد في سبيل اللها (').

وقال: لافهذا الجيش المصري الذي هو جزء من هذه الجيوش، ونسخة

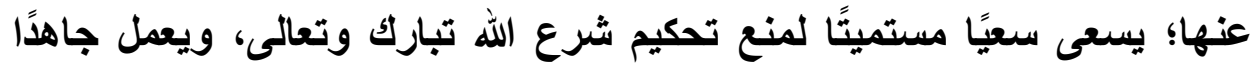

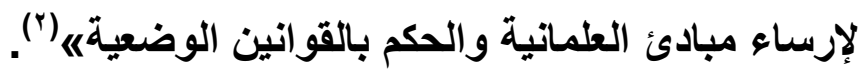

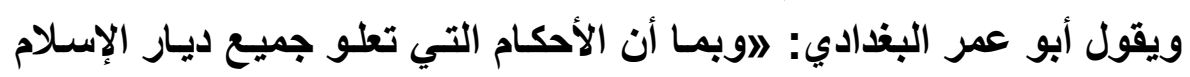
اليوم هي أحكام الطاغوت وشريعته، فإنتا نرى كفر وردة جميع حكام تلك التول الدول

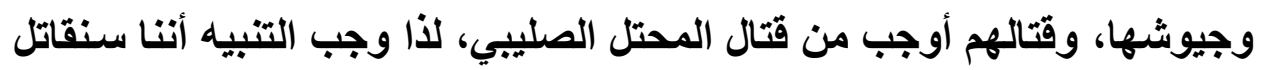

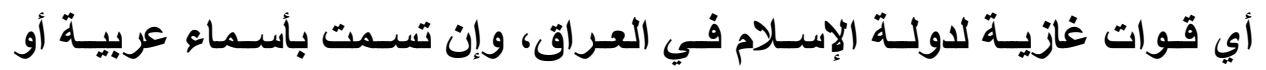

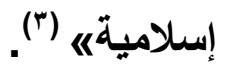
المسألة الثانية: الرد على الثلى الثبهة: لا شك أنَّ مسألة الحكم بما أنزل الله من أعظم القضائه القدا، وأهم المسائل التي

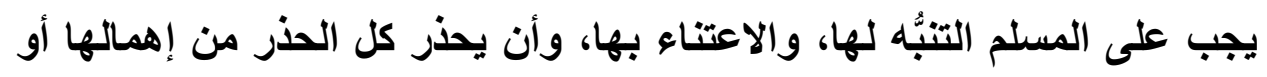
التغافل عنها، فضلًا عن تركها وعدم العمل بها.

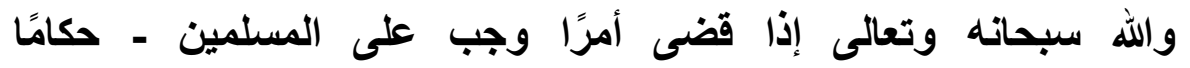

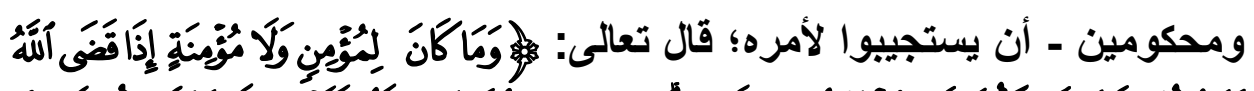

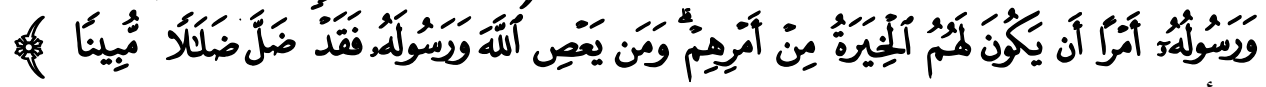

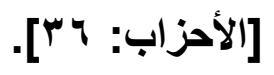

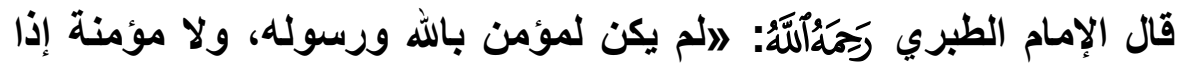

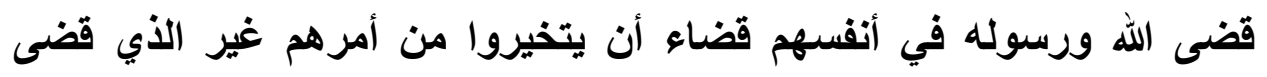
فيهم، ويخالفوا أمر الله وأمر رسوله وقضاءهما فيعصوهما، ومن يعص الله

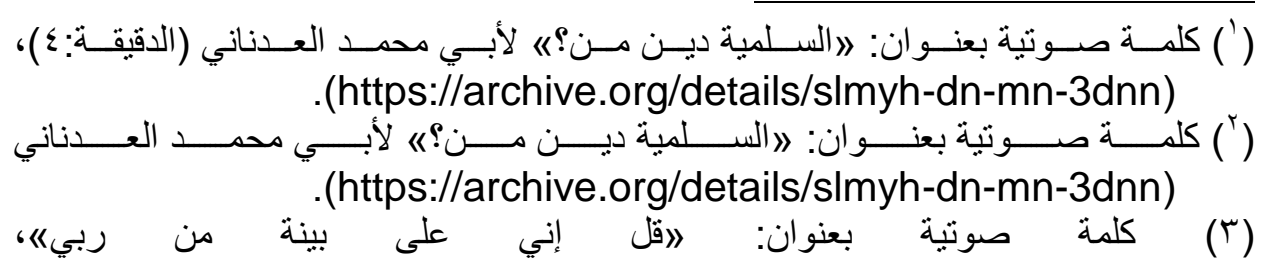
.(https://archive.org/details/byntn) 
ورسوله فيما أمَرَا أو نهَيَا ... فقد جار عن قصد السبيل، وسلتك غير سبيل الهُي

والرشاده (').

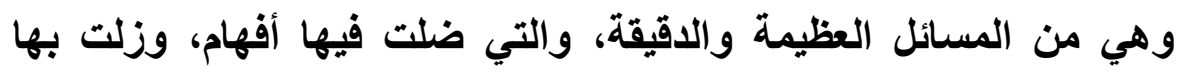

أقدام، وينبغي نبذ الهوى فيها، والتأليف بين نصوصها، وفهمها كما فهمها

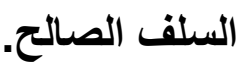

ويمكن أن يتم تأصيل هذا الباب، ذكر قواعد تبين مسائله، وتنتظم تحتها

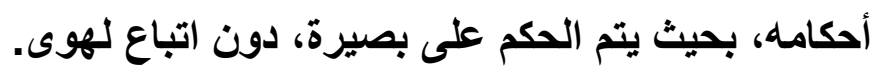
القاعدة الأولى: أن الحكم بغير ما أنزل الله لا يكون التبكفير فيه لهيه مطلقا.

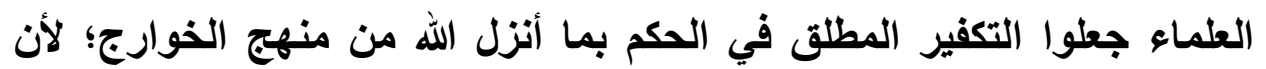

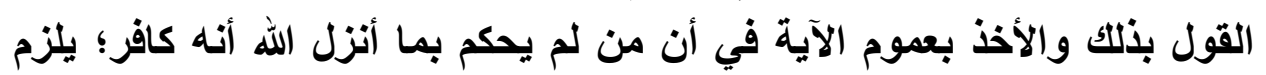
منه تكفير المسلمين في أي حكم جاروا فيه فئ.

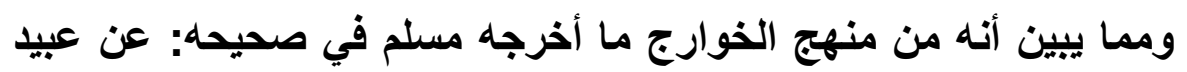

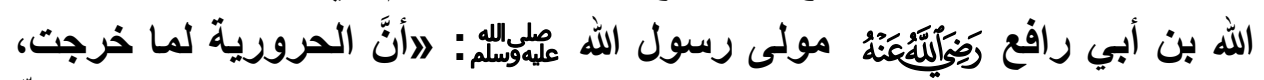

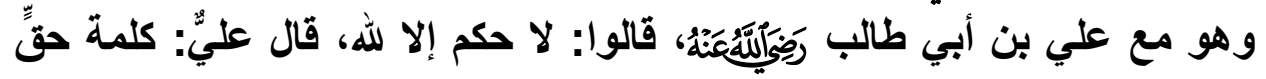

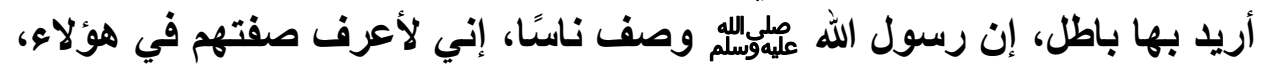

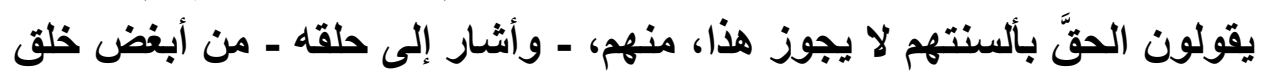
الله إليهاه (†).

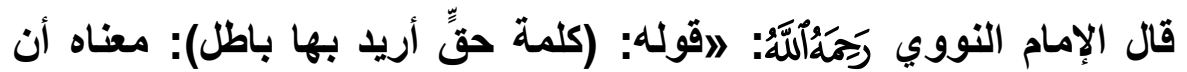

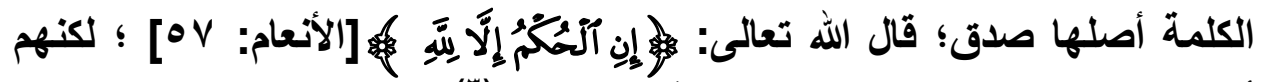

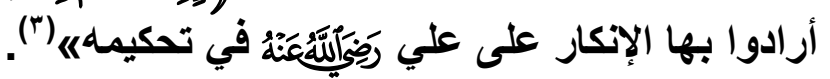
وقد ذكر أبو الحسن الأثعري إجماع الخوارج على تكفير علي رضي الله

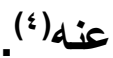
و التكفير بالإطلاق عند الخوارج لمن لم يحكم بما أنزل الله، والاستدلال على

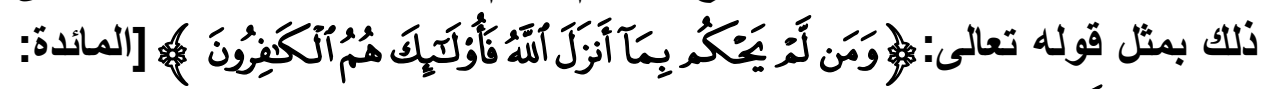
؛ ؛]

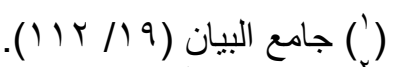

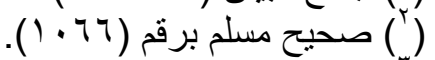

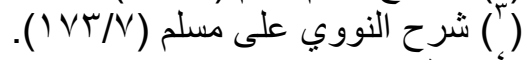

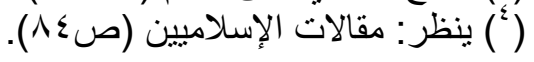




$$
\text { بحسب الأحوال والصور، وهذا يوضحه: }
$$

القاعدة الثانية: ليس كل حكم بغير ما أنزل الله يكون داخلا في النهي.

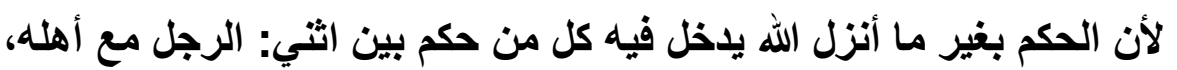

\section{والمعلم مع طلابه، والرئيس مع مرؤوسيه.}

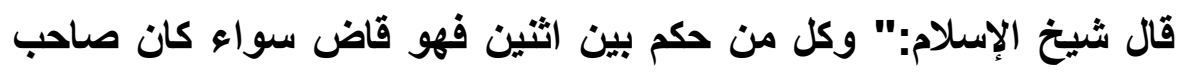

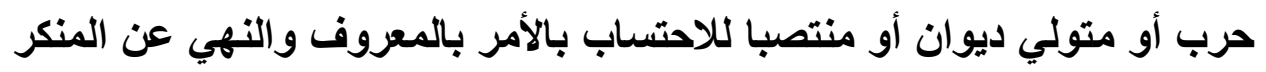

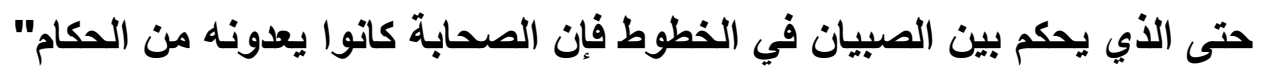

والخوارج لا يرون جواز ذلك مطلقا، وأصل الثبهة عندهم: أنهم أخذوا

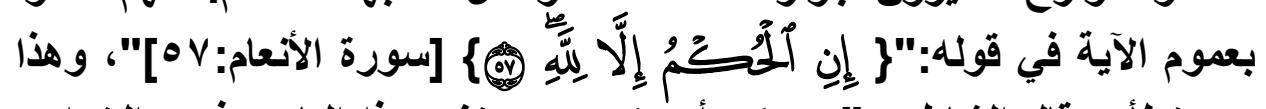

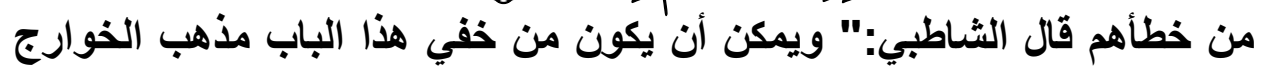

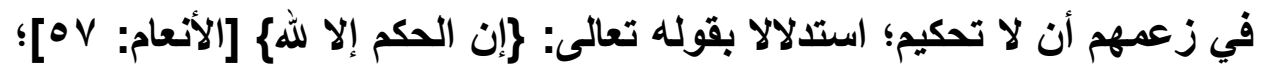

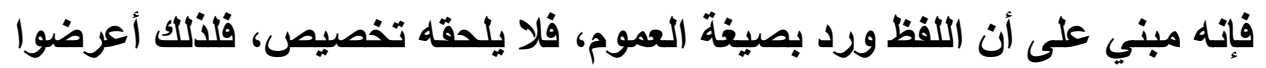

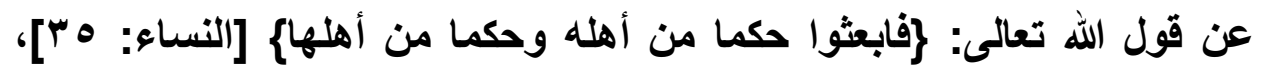

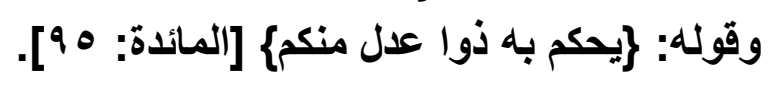

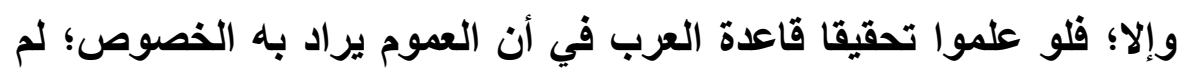

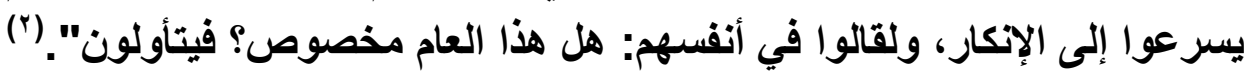

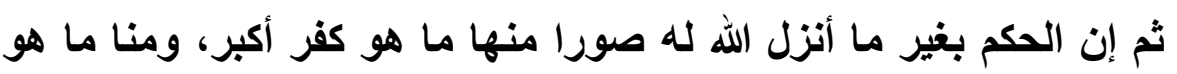

$$
\text { كفر أصغر. }
$$

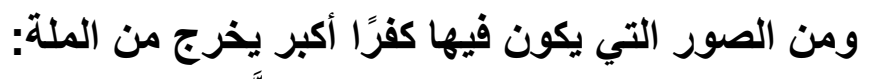

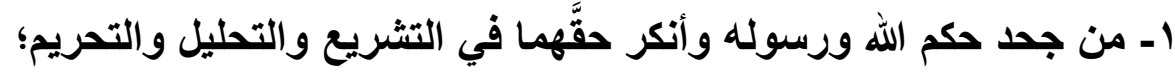

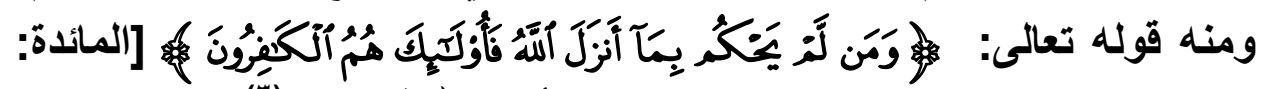

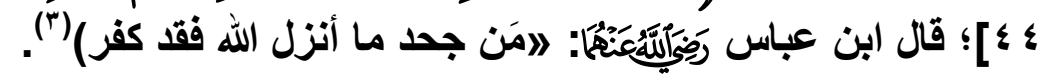

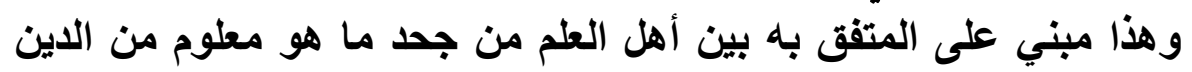

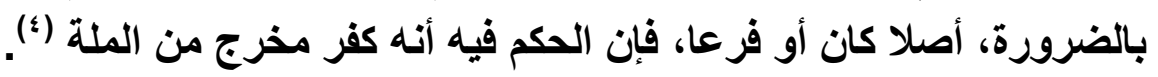

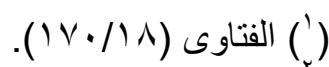

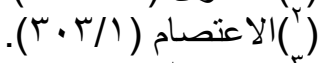

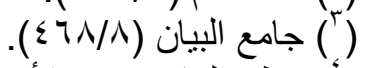

$$
\begin{aligned}
& \text { (") ينظر:الحكم بغير ما أنزل الله د. عبدالرحمن المحمود (ص1091) } \\
& 149
\end{aligned}
$$




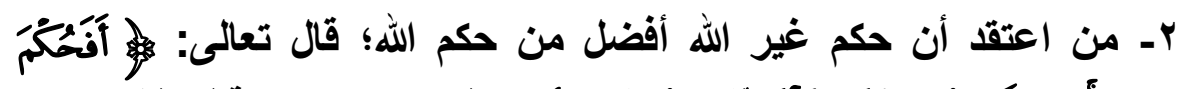

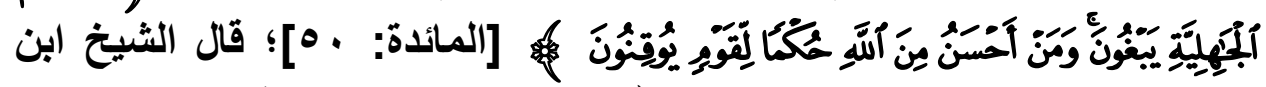

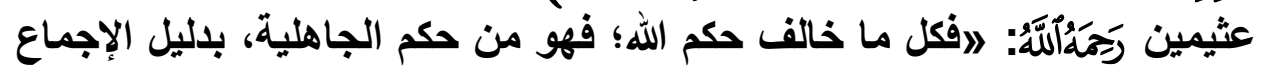

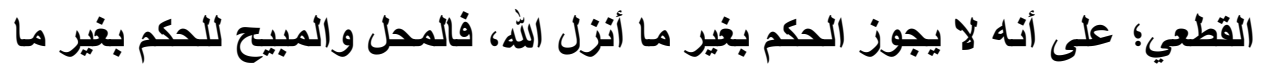

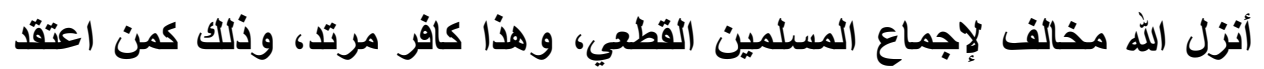

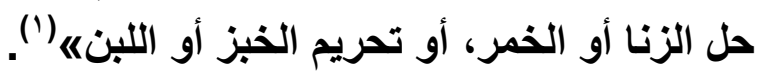

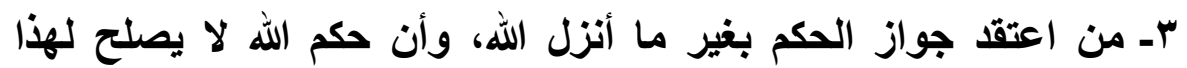

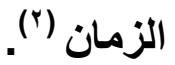

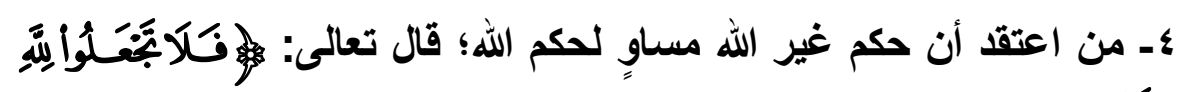

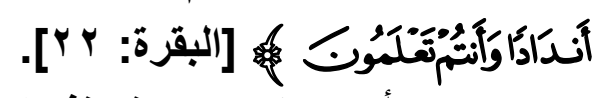

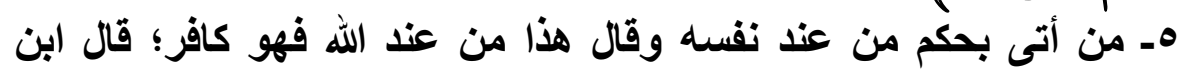

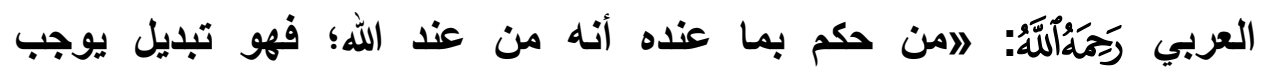

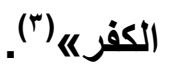

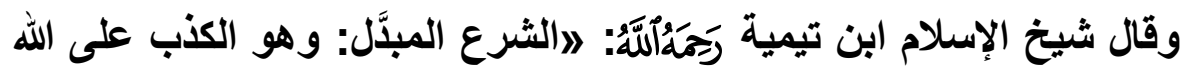

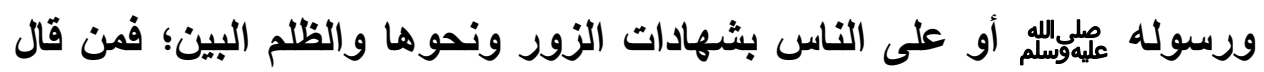

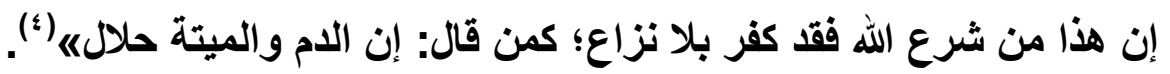

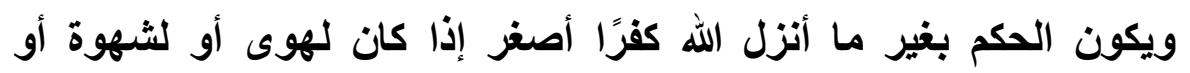

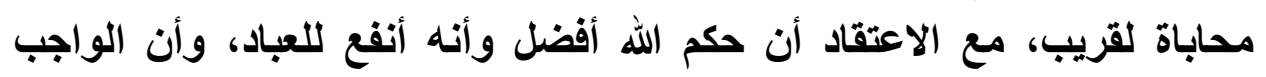

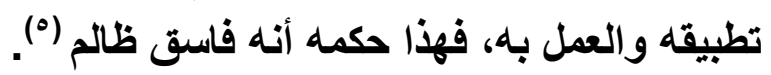

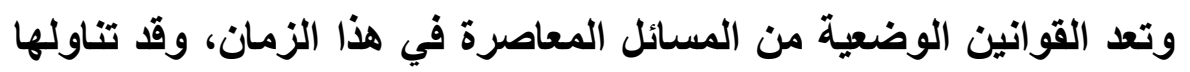

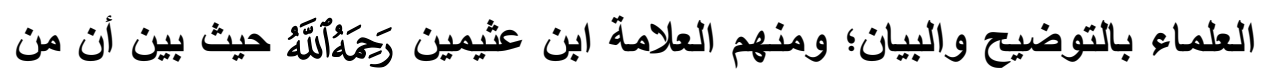

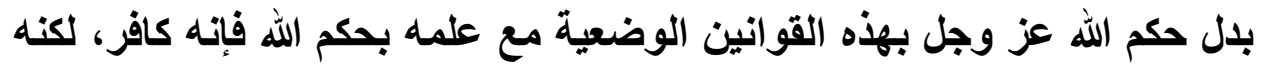

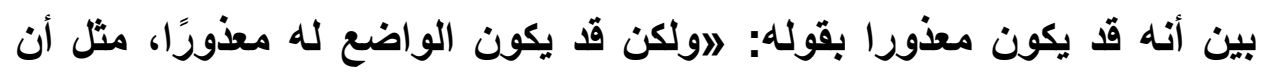

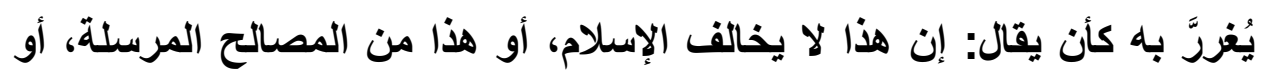

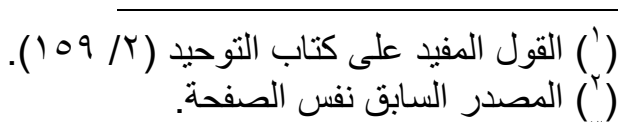

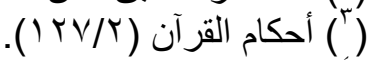

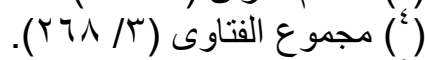

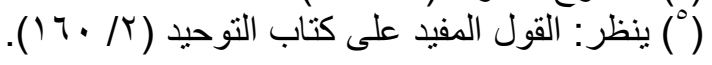

$$
\begin{aligned}
& 1 \% \text {. }
\end{aligned}
$$


هذا مما رده الإسلام إلى الناس فيوجد بعض العلماء وإن كانوا مخطئين يقولون:

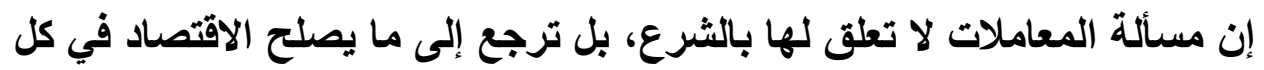
زمان بحسبه، فإذا اقتضى الحال أن نضع بنوكا للربا أو ضرائب إنب على فئى الناس؛ فهذا لا شيء فيه.

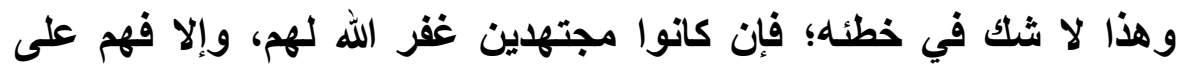

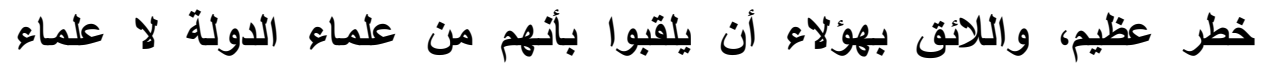
الملة هاب (').

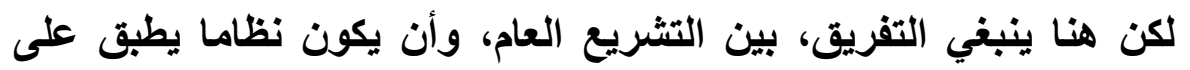

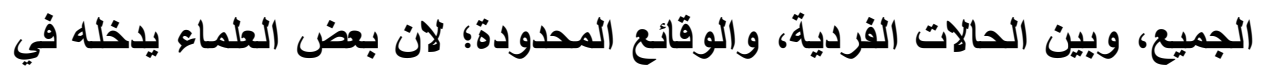

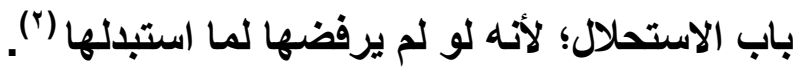
وقد نقل غير واحد من أهل العلم الإجماع على كفر من حكم بغير ما أنزل الله لهالهائل حكما عاما (r) ومع هذا فإن من وضعه أو عمل به لا يكفر حتى تقوم عليه الحجة ممن هو

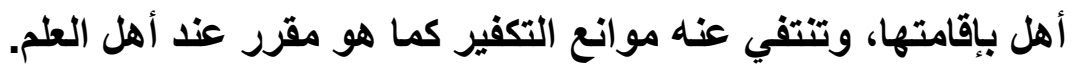

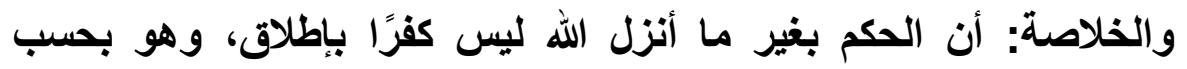

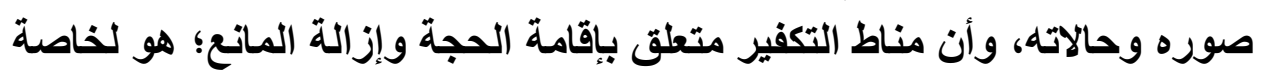

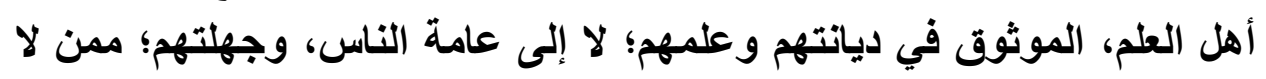

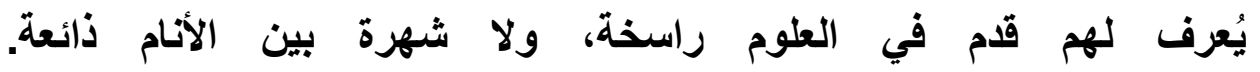

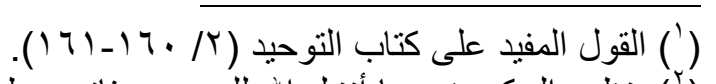

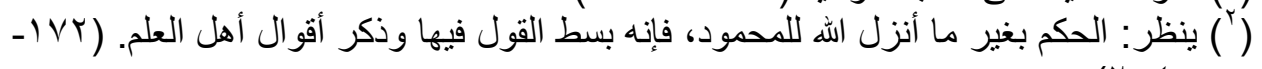

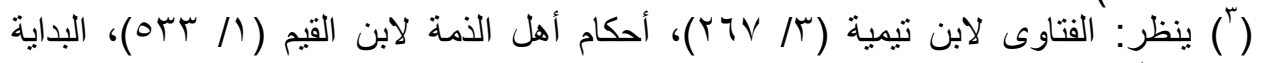
و النهاية لابن كثير (IV/ V I I I ) . 


\title{
المطلب النانهي
}

\section{شبهة تككهير الديار كونـها محكومة بـالقوانـين الوضعية}

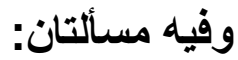 \\ المسألة الأولى: عرض ملئان: الثبهة:
}

الحكم بالقوانين الوضعية كفر أكبر مخرج من الملة، وإذا كان كذلك؛ فإن

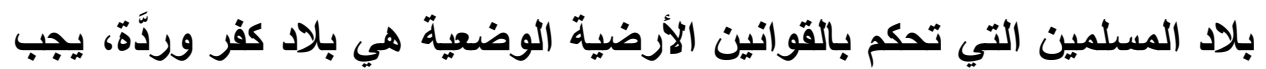

قتال حكامها الطواغيت الكفرة!

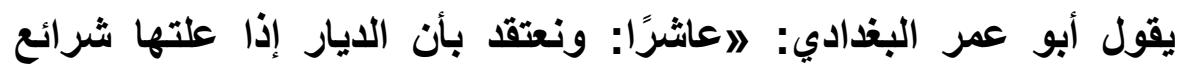

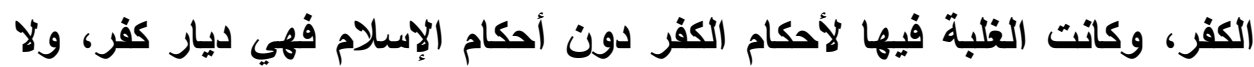
يلزم هذا أن نكفر ساكني الديار، وبما أن الأحكام التي تعلو جميع ديار الإسلام الإم الإملام اليوم هي أحكام الطاغوت وشريعته، فإنتا نرى كفر وردة جميع انيع حكام تلكك الدول وجيوشها، وقتالهم أوجب من قتال المحتل الصليبي، لذا وجب التببيه أنتا سنقاتل

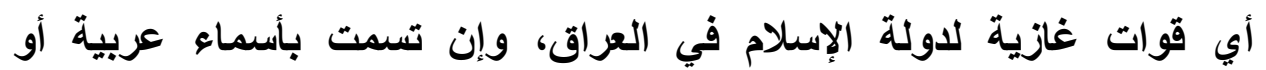

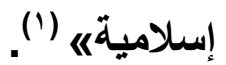

المسألة الثاتية: الرد على الثبهة: فنحن أمام تكفير لأنظمة تحكم الدول الإسلامية بعلة الحكم بغير ما أنزل الله

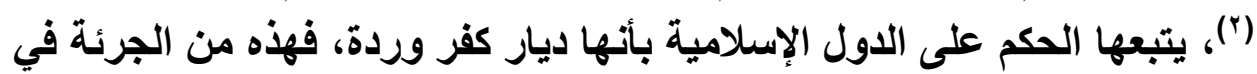

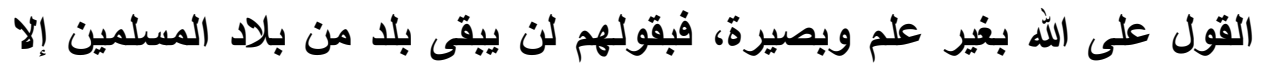

والجواب عن هذه الثبهة أن يقال:

دولتهم.

هذا المسألة من المسائل الدقيقة التي تصدى لهده لها بعض التنظيمات، وترتب

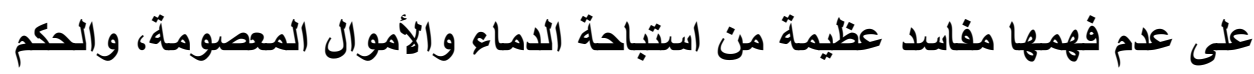

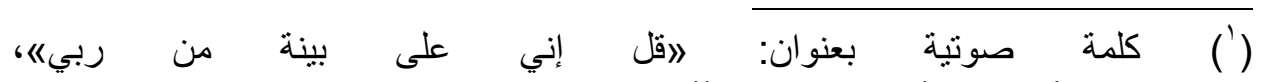
.(https://archive.org/details/byntn)

( ) وقد رُدّ على هذه المسألة في المطلب السابق. 
بالكفر على جميع البلاد الإسلامية؛ مما يوجب بيان هذه المسألة والرجوع لكلام أهل العلم فيها. لا با من التفريق بين دار الإسلام ودار الكفر:

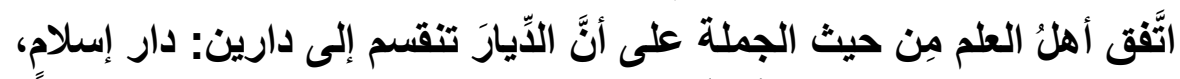

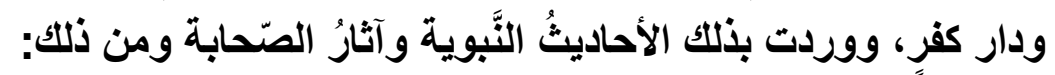

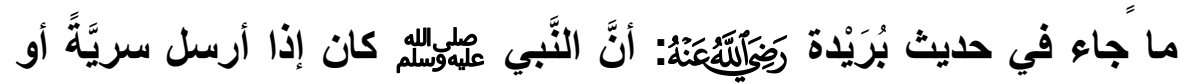

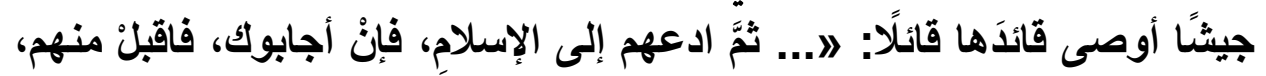

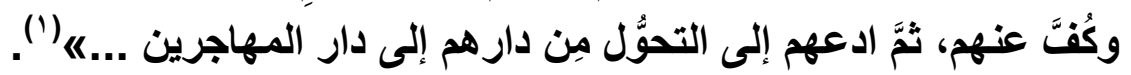

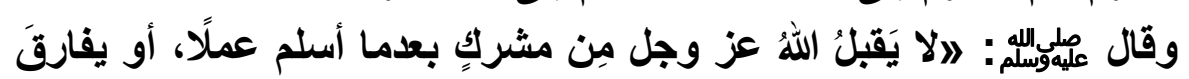

المشركين إلى المسلمينه (r). وقد بيَّن العلماء أن هنالك فرقًا بين كلا الداريْن، فالدار التي يغلب عليها

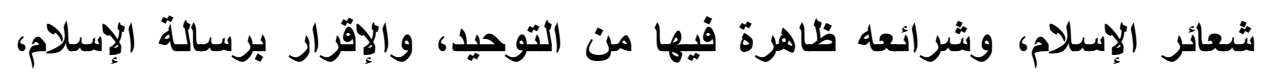

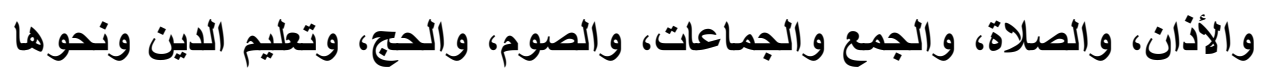
فهي دار إسلام.

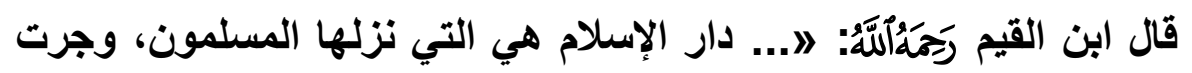
عليها أحكام الإسلام، وما لم تجر عليه أحكام الإسلام لم يكن دار إسلام...." آمات.

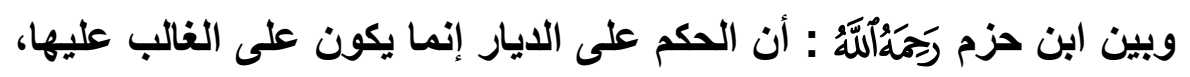

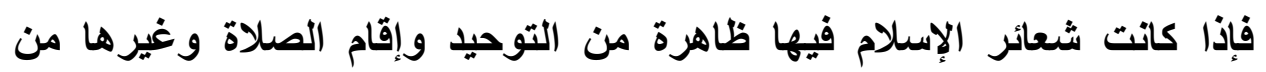

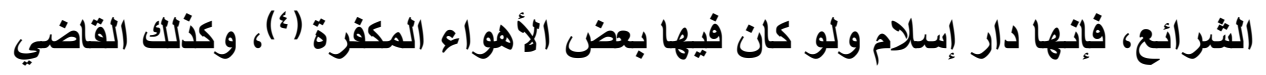
أبو يعلى (0). فإذا عرفنا أن دار الإسلام هي التي كان فيها الغلبة لأحكام الإسلام، وكاتت المنعة والقوة للمسلمين، وإن أقام فيها بعض العض الكفار.

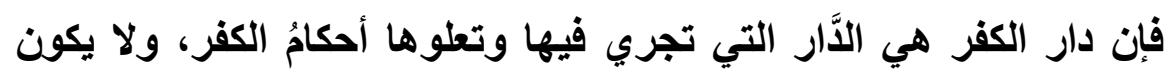

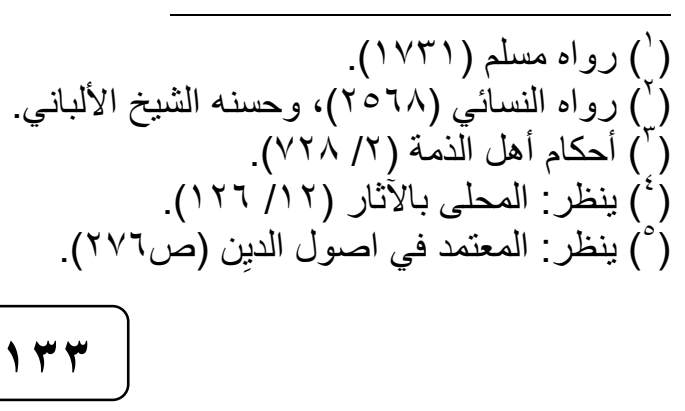


فيها السُّلطانُ والمنعةُ بيد المسلمين، وإنْ أقام بعضُهم بهاب(') وتنقسم إلى قسمين:

دار حرب: وهي دار الكفر التي ليس بينها وبين المسلمين عهلٌ ولا أمان،

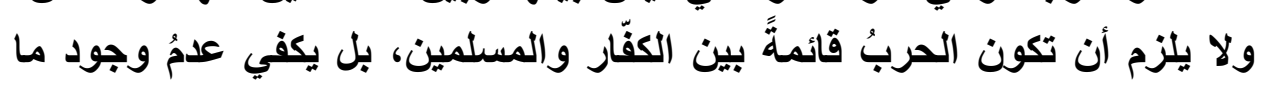
يمنعها مِن عهةٍ أو أمان. ودار عها: وهي دارُ الكفر التي بينها وبين المسلمين عهدٌ بترك القتال مِن

صلحِ أو هدنة (r).

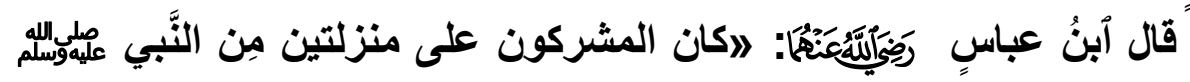

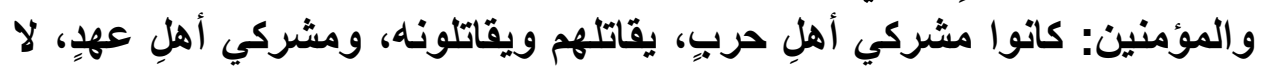

يقاتلكهم ولا يقاتلونهاه (")

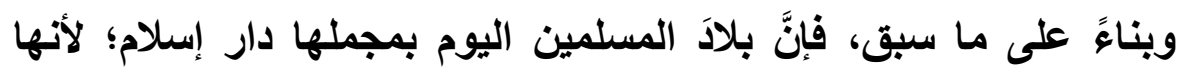

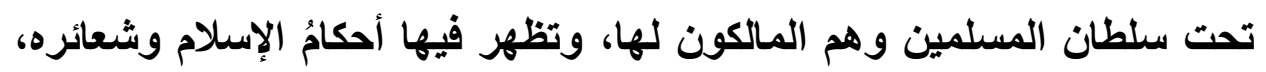

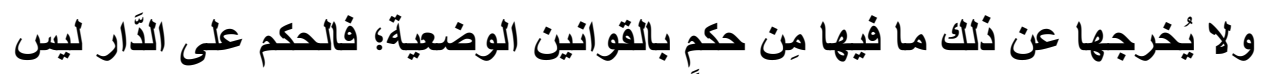
حكمًا بالضَّرورة على السُّلطة الحاكمةً لها.

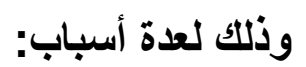

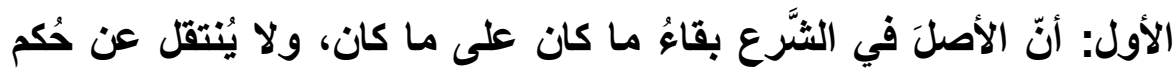

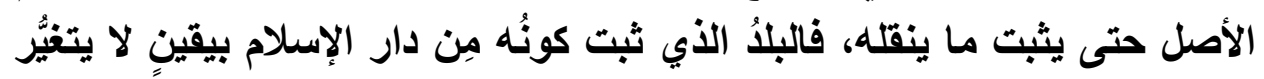

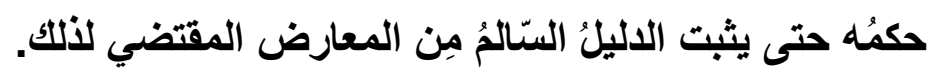

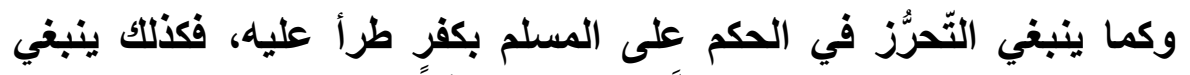

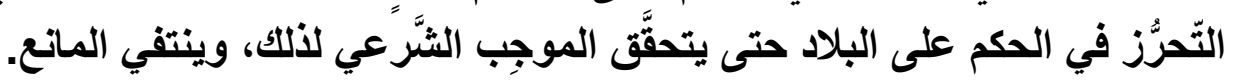

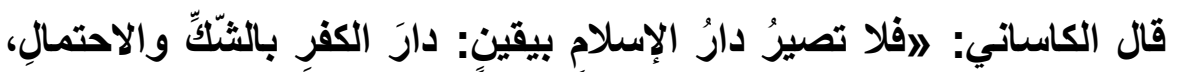

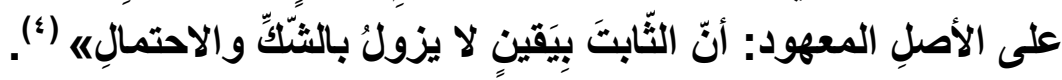

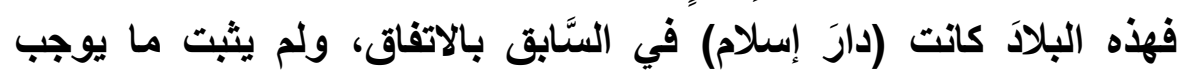
تحوَّلها إلى ديار كفرٍ.

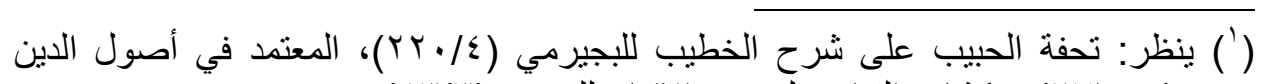

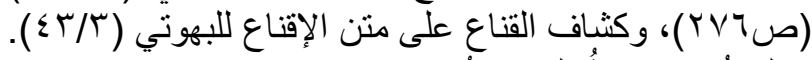

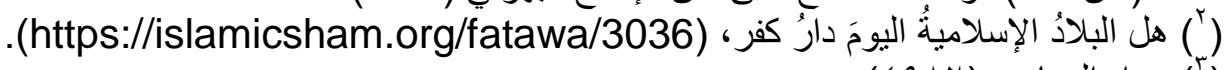

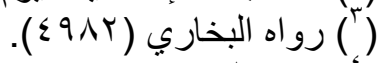

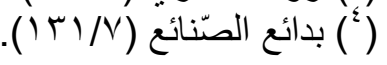




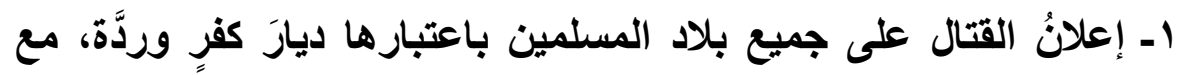

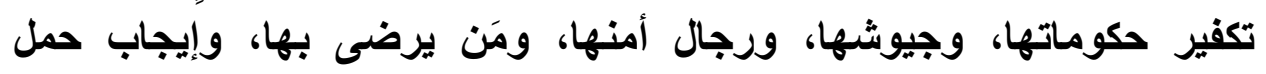

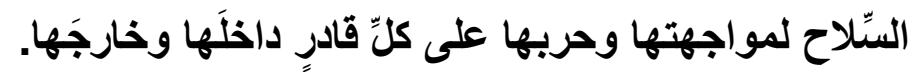

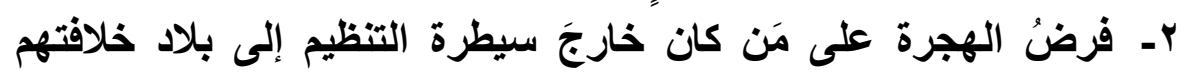

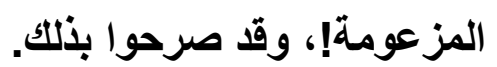

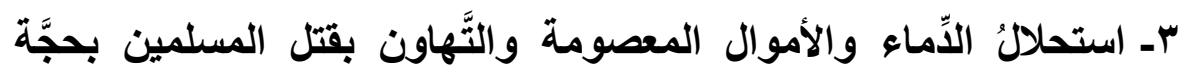

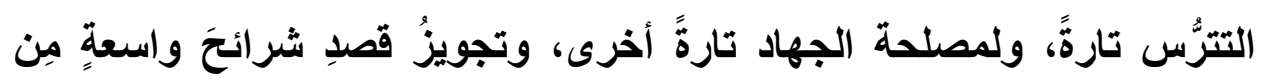

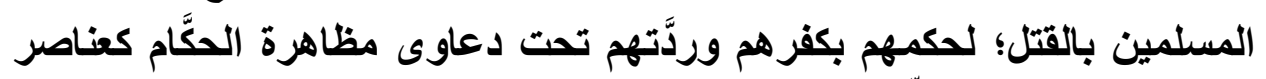

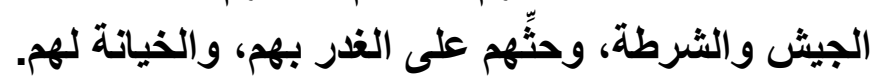

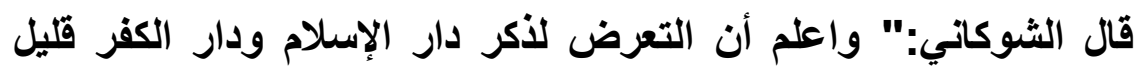

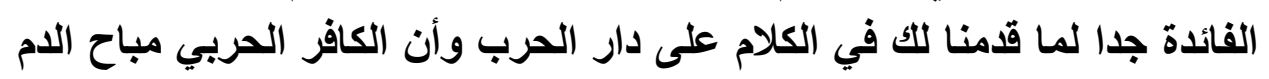

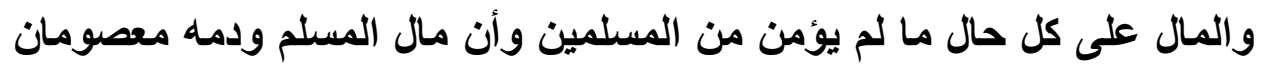

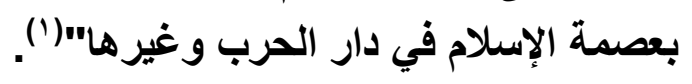

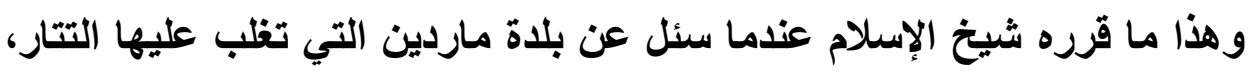

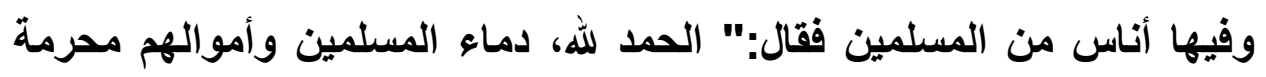

$$
\text { حيث كانوا في " ماردين " أو غيرها...." (؟). }
$$




\section{المطلب الثالث}

شبهة تكفير من والى الكفار على المسلمين

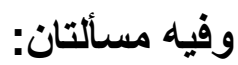

المسألة الأولى: عرض مان: الثبهة:

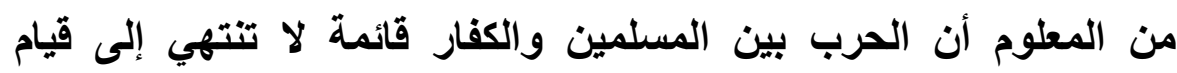
الساعة، وأن من والى الكفار على المسلمين من أهل الإسلام وأعانهم في حربهم

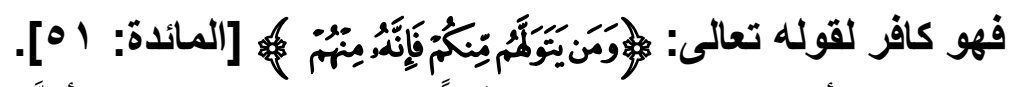

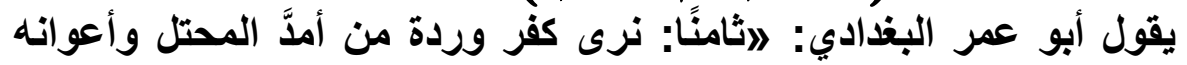

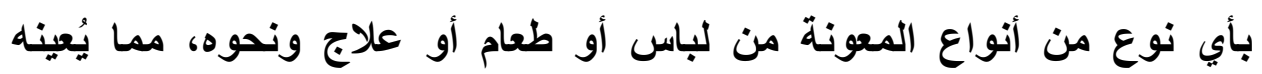

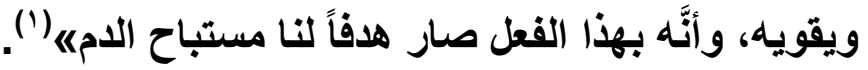

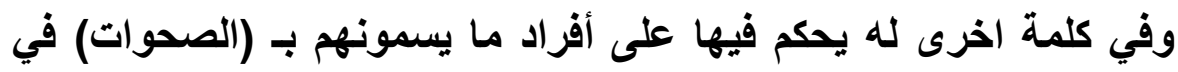

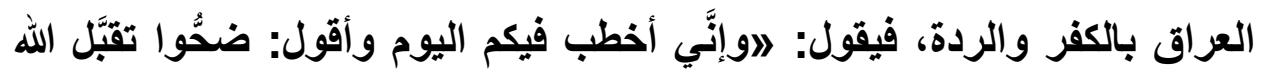

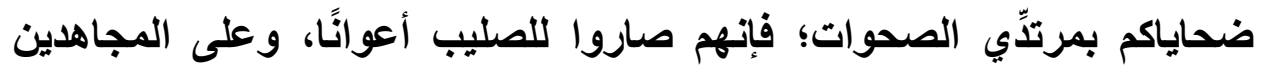

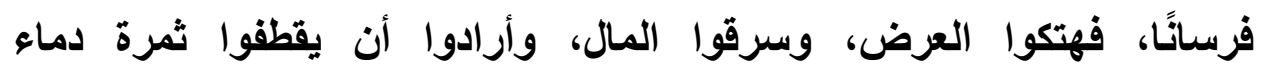

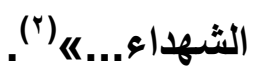

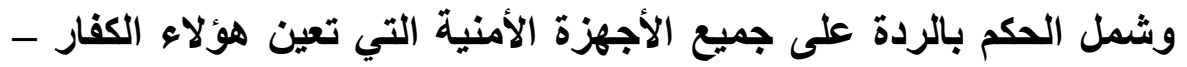

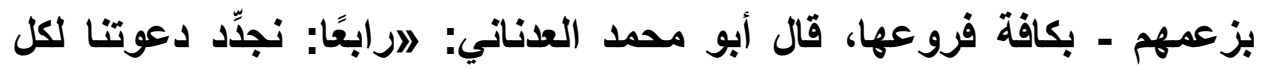

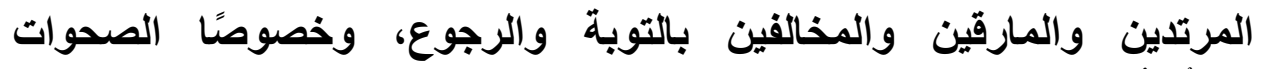

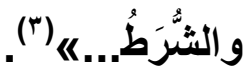
المسألة الثانية: الرد على الثبهة: من خلال ما تقام نلاحظ إطلاق التظيم لفظ المرتدين على كل من كان في

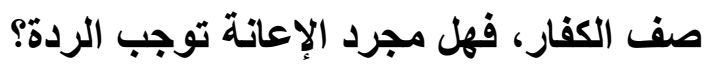
وينبغي في معرض الرد على الثبهة أن أقدم بأربع مقدمات:

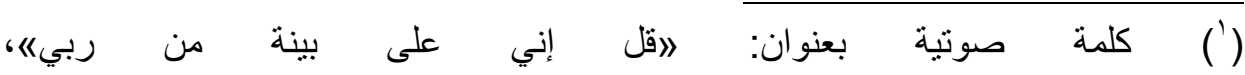
.(https://archive.org/details/byntn)

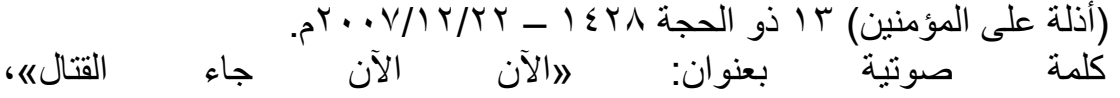
.(https://archive.org/details/ja2.alqetal) 
الأولى: أن من تولى كافرًا في حربه ضد المسلمين لا شكك أنه قد وقع في

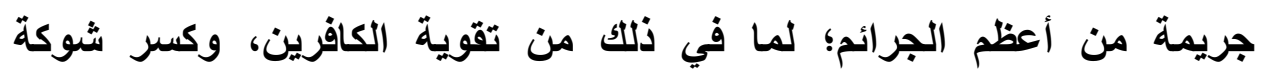

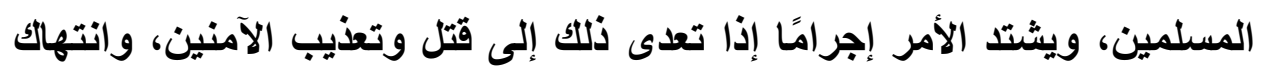

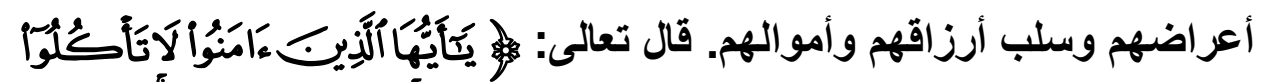

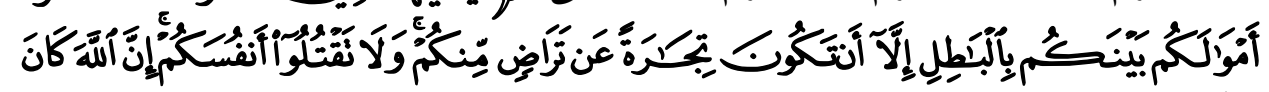

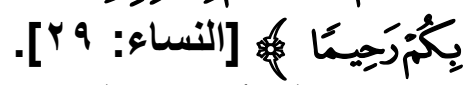

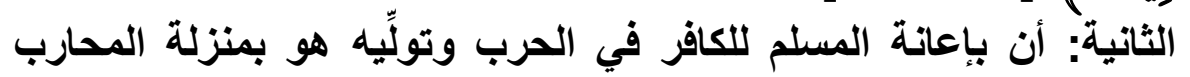
الكافر، لا يمنع من دفع صولته وقتله؛ فحكمه كحمم الكافر الصائل.

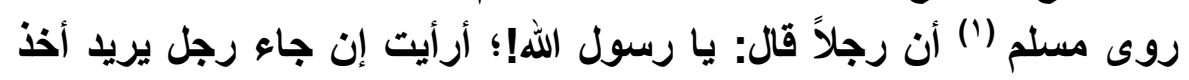

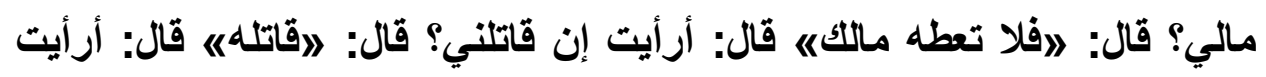

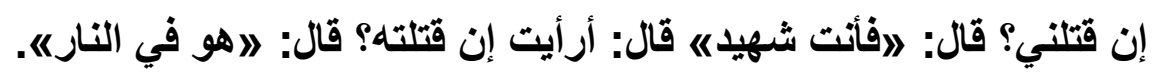

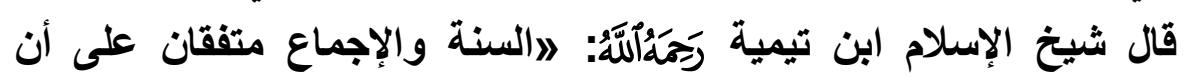

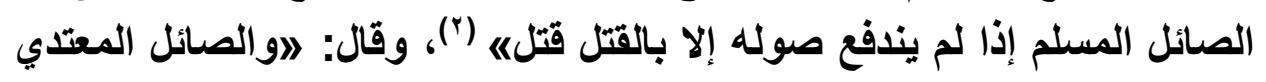
يستحق دفعه سواء كان مسلمًا أو كافرًا الها (").

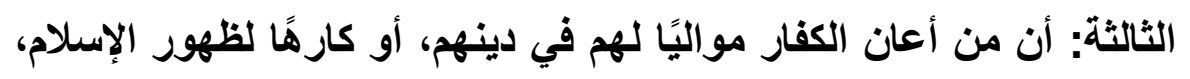

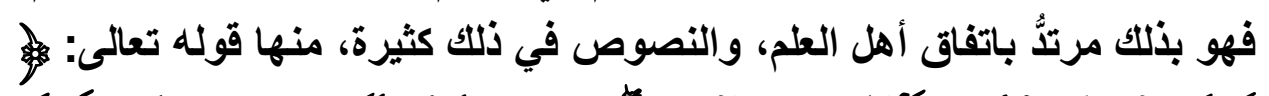

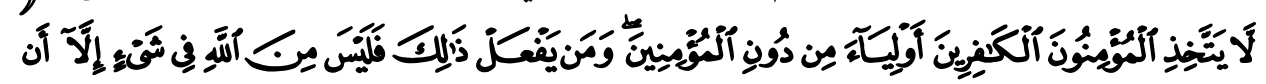

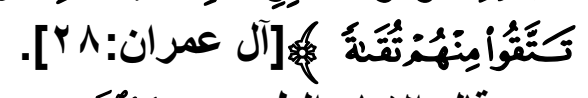

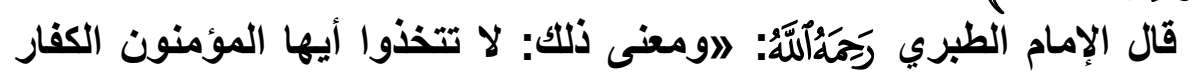

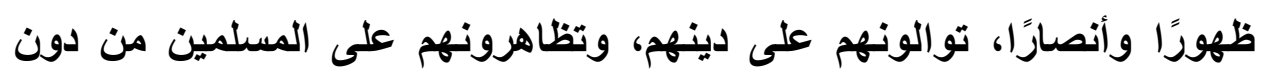

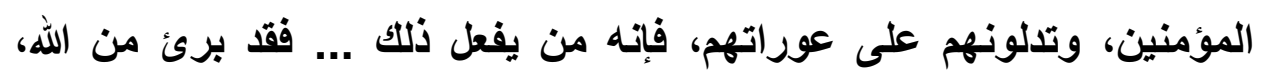

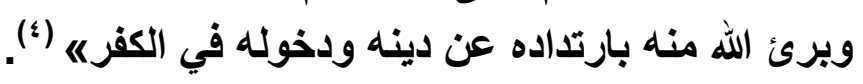

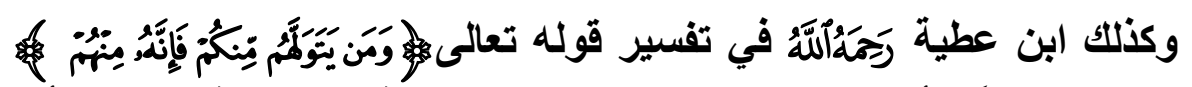
[المائدة: 10]: بيَّن أن المقصود: من تولاهم بمعتقده فهو منهم في الكفر، أما فئ

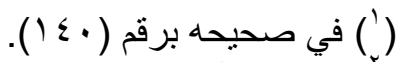

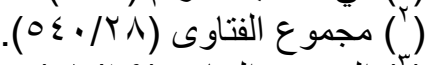

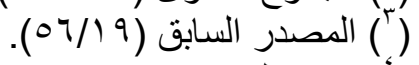

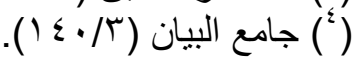

$1 \mathrm{r}$ 
من تولاهم بفعله دون الاعتقاد فإنه منهم في المقت والأم(').

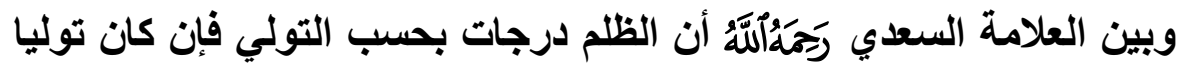

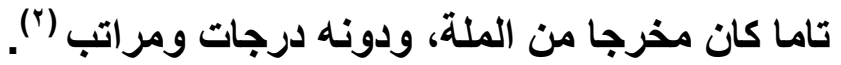

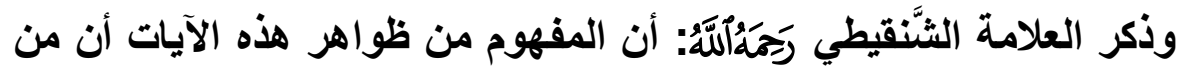

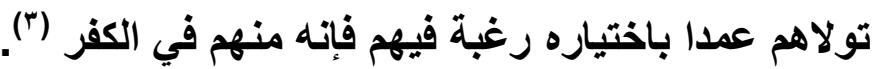

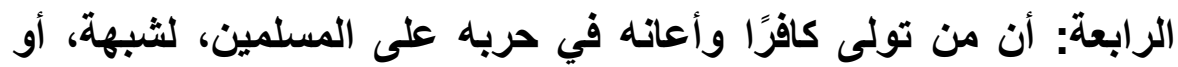

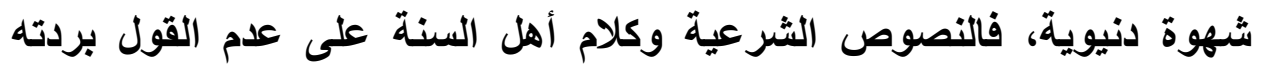
وكفره لمجرد هذه الإعانة.

فهناك فرق بين تولي الكافر محبة له في دينه، وبين توليه لشهوة أو

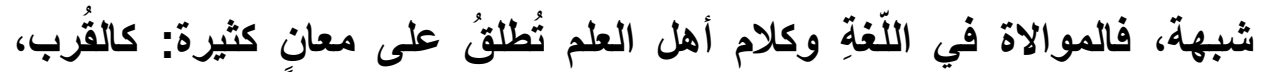

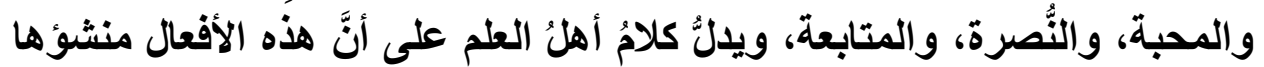

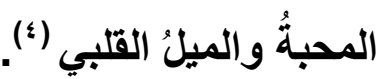

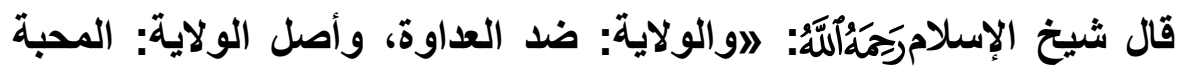
والقرب، وأصل العداوة: البغض والبعد ... والولي: القريب، يقال: هذا يلي هذا، أي يقرب منهس(ن). ومن الأدلة على بطلان إطلاق التكفير في مسالة التولي مسألة التجسس

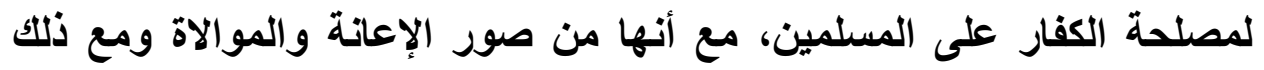
ذهب عامة العلماء إلى أنَّ التجسسَ للكفار على المسلمين مِن الكبائر والمعاصي

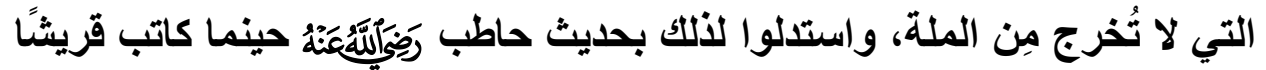

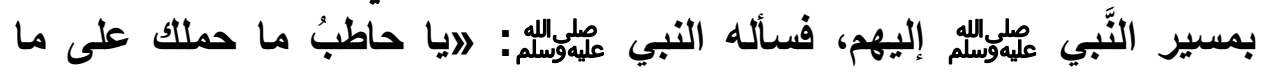

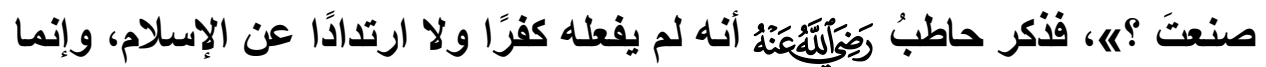

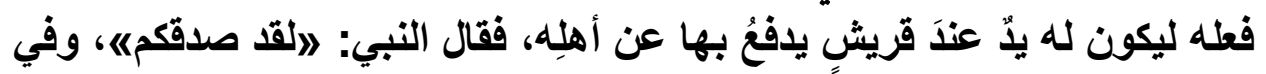

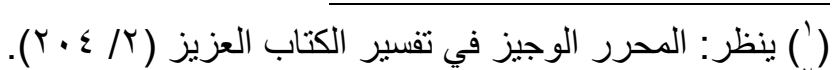

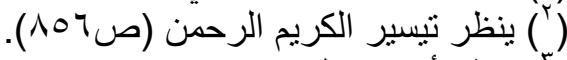

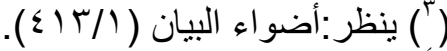

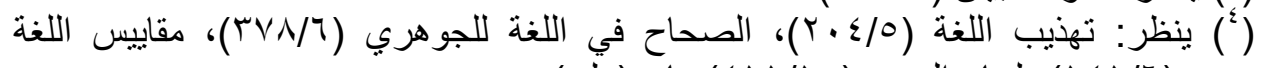

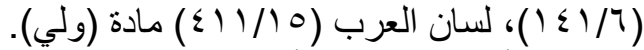

( ) الفرقان بين أولياء الرحمن وأولياء الثيطان (صاده) (ول). 


$$
\text { لفظ: لاولا تقولوا له إلا خيراً ('). }
$$

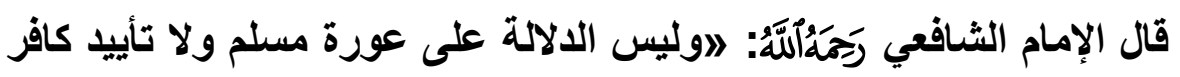
بأن يحذر أن المسلمين يريدون منه غرة ليحذرها أو يتقدم في نكاية المسلمين

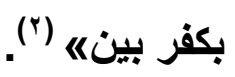

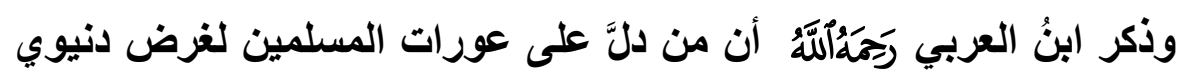

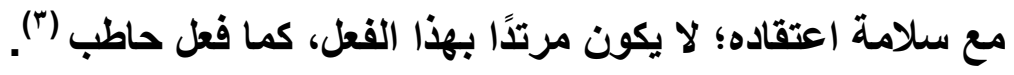

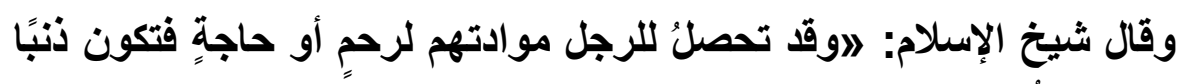

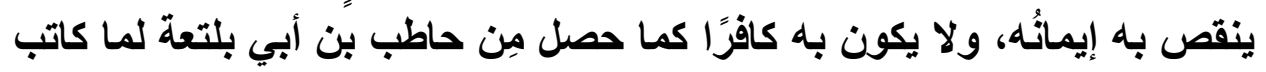

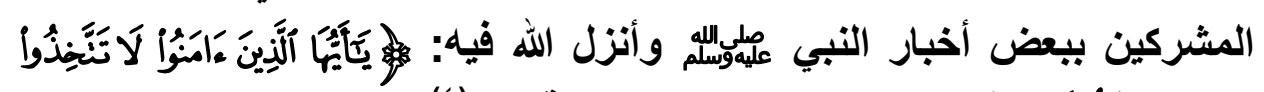

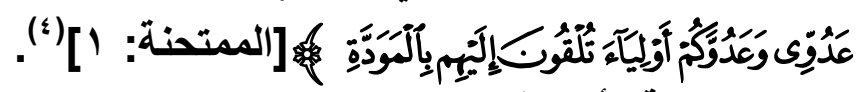

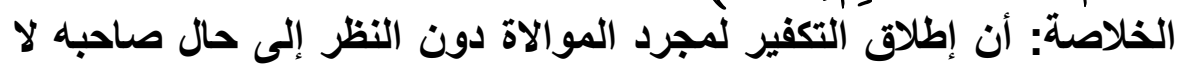

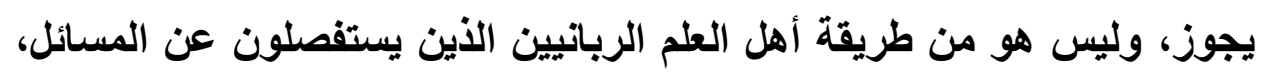

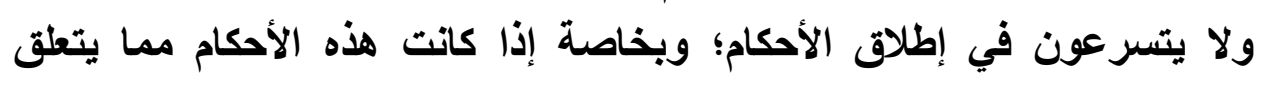

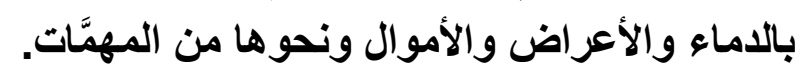

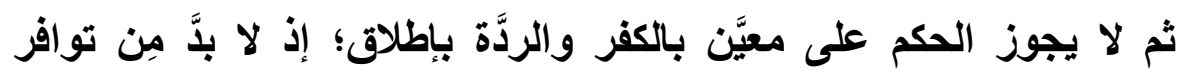

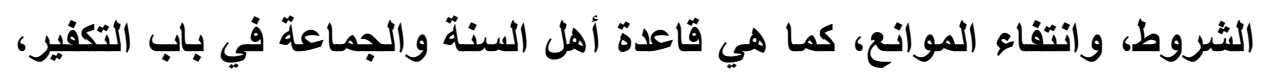
خلافًا لأهل الغلو.

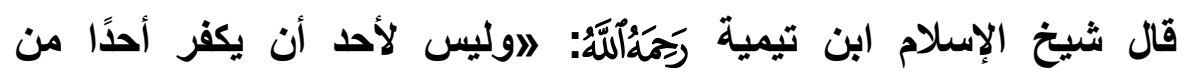

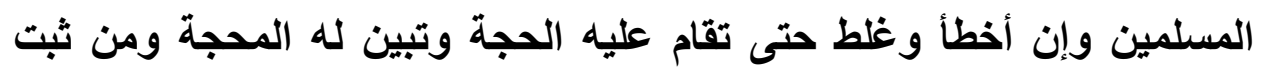

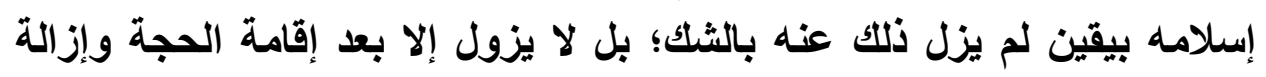

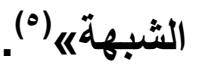

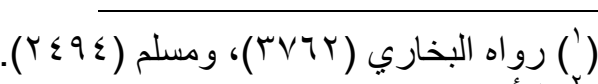

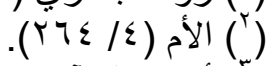

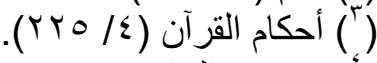

$$
\begin{aligned}
& \text { () }
\end{aligned}
$$

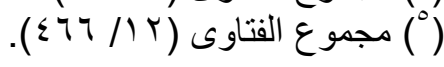




\section{المطلب الرابـر \\ شبهة تكهير الجيوشر في الدول الإسلالمية}

وفيه مسألتان:

المسألة الأولى: عرض ملئان: الشبهة:

بما أن الحكم بغير ما أنزل الله تعالى كفر وردة، وأن الحاكم بالقوانين الوضعية كافر= فإن من يحمي هؤلاء الحكام من الجيوش والمؤسسات العسكرية كافرة مرتدة!

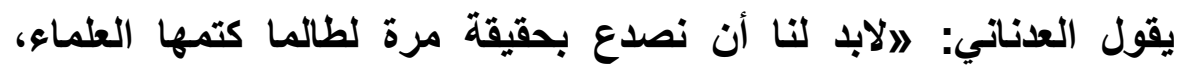
واكتفى بالتلميح لها الفقهاء؛ ألا وهي: كفر الجيوش الحامية لأنظمة الطواغيت، وفي مقدمتها الجيش المصري، والجيش الليبي، والجيش التونسي، قبل الثورة

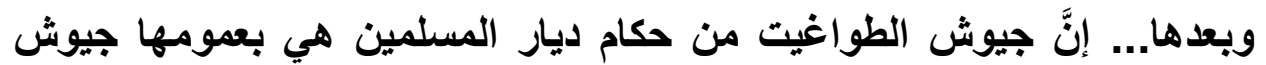

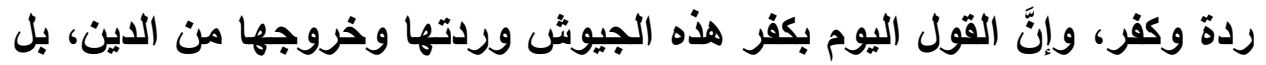
ووجوب قتالها وفي مقدمتها الجيش المصري لهو القول الأي لا يصح في دين الله خلافه ... فهذا هو الجيش المصري الأي هو جزء من هذه هونها الجيوش ونسخة

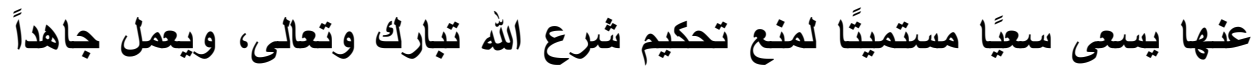

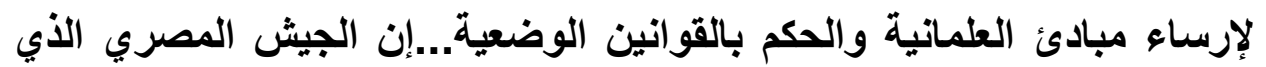
هو نسخة عن تلاك الجيوش جيش يحمي البنولك الريوية، ودور الخنا، والعهر، وحامي حمى اليهود، والأقباط والنصارى، المحاربين لله ورسولهيه (')

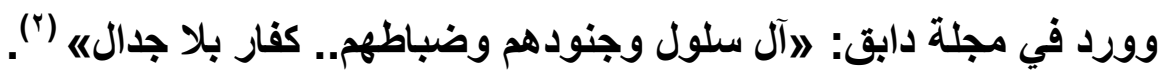

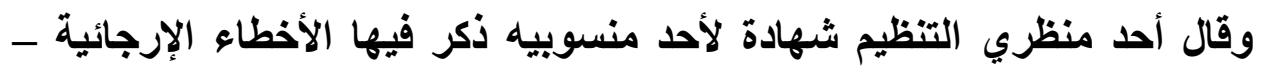

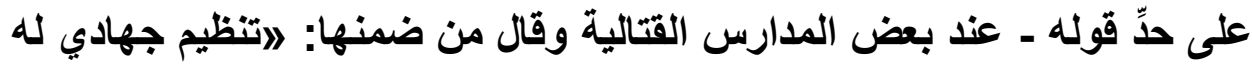

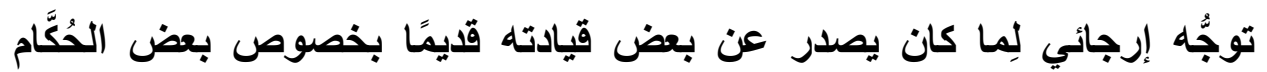
المرتدين، خاصةً آل سعود، وعساكرهم، وان والتوقف في ردتهمه (").

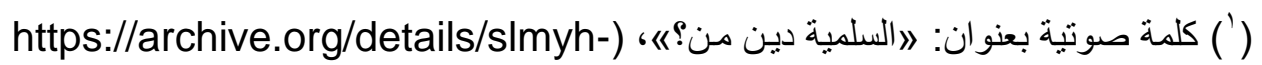
.(dn-mn-3dnn

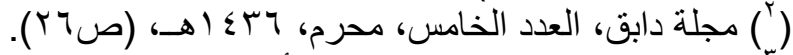

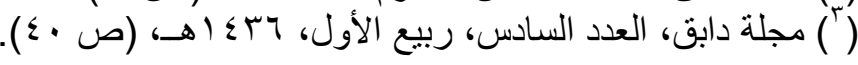




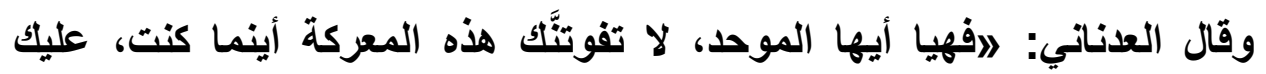

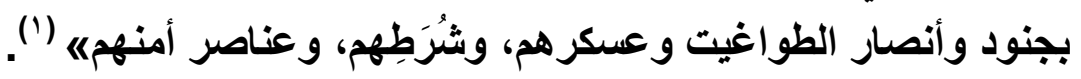
المسألة الثانية: الرد على الثبهة:

وكلام التظيم في تكفير جيوش البلاد الإسلامية كثير جدًا، ونالت بلات بلادنا

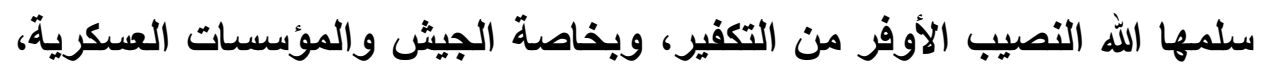

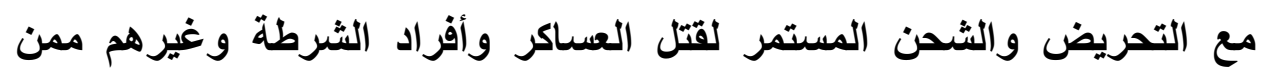
يعملون في السلك العسكري. والسؤال هنا: هل الحكم بالردة الذي أصدره التنظيم خاص بالجيوش التابعة

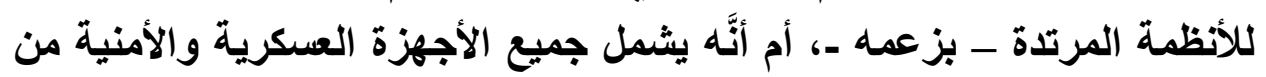

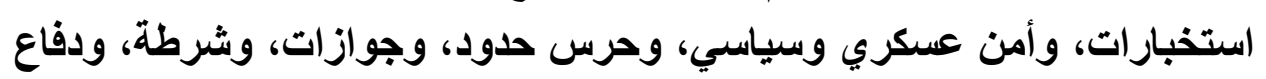

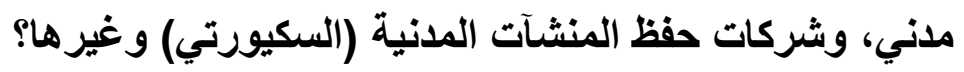

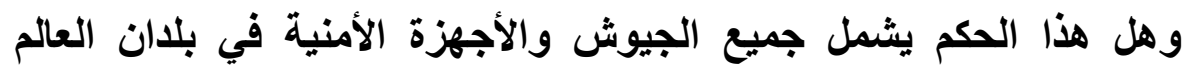

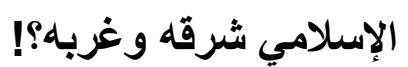
فإذا كاتت الجيوش مرتدة لخضوعهابها للألنظمة المرتدة وقبولها بأحكامها،

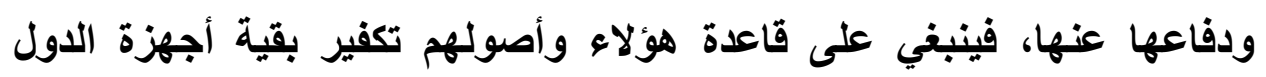

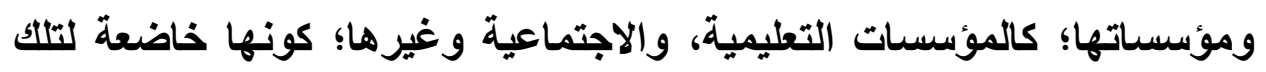

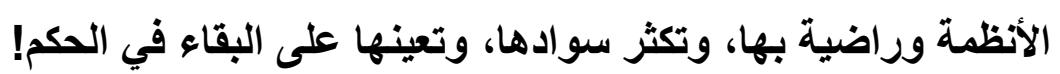

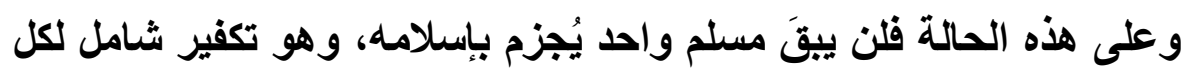

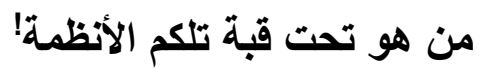

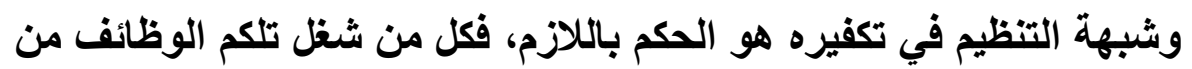

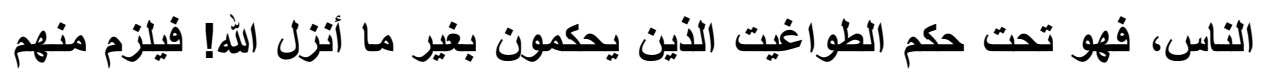

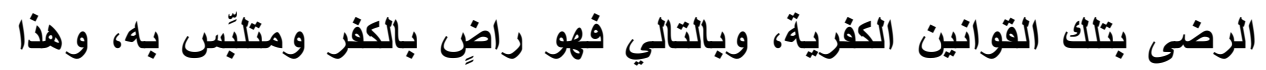
الفهم المغلوط يؤدي بهم إل تكفير المجتمعات الإسلامية.

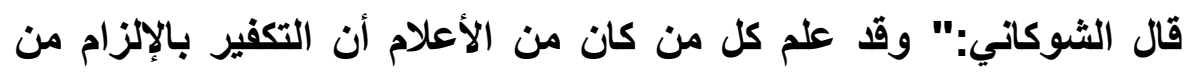

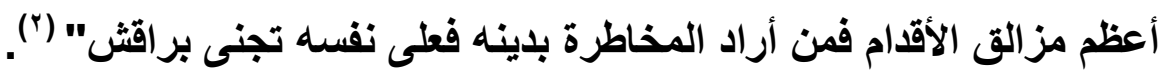

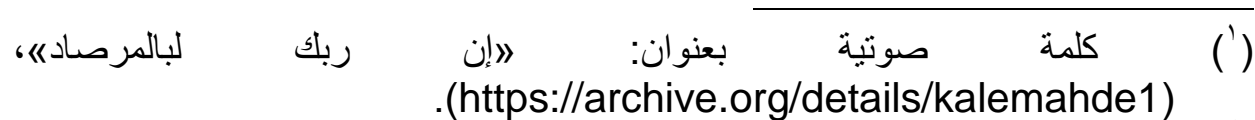

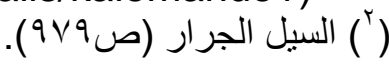




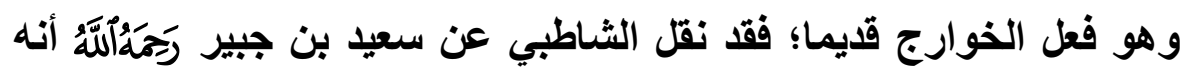

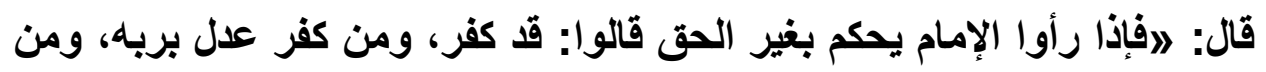

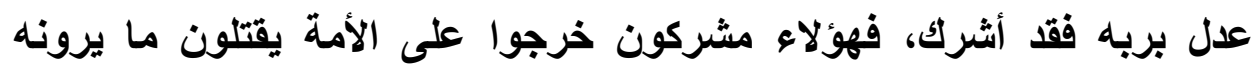

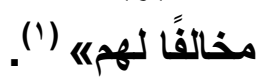

ولو سلمنا جدًا أن أفرادًا من الجيش والثرطة قد وقعوا في الكفر نتيجة

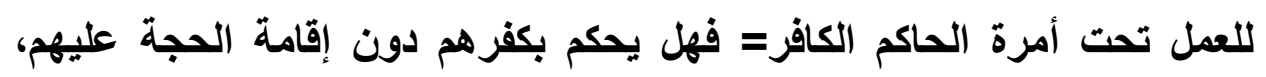

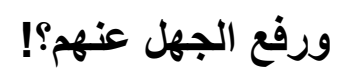

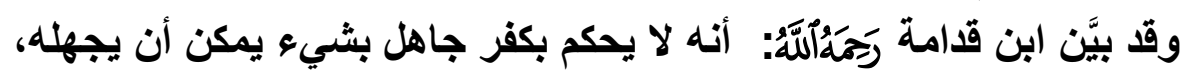

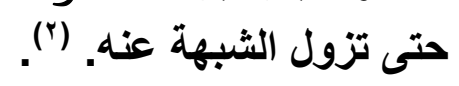
ونقل القاسمي عن ابن العربي عذر الجاهل ولو كان عمله كفرا أو شركا

تبيَّن له الحجة التي يكفر بعد إقامتها عليه (").

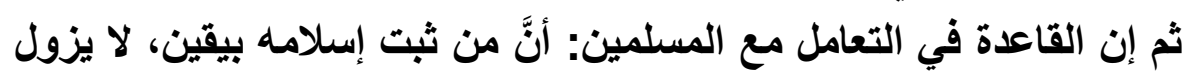

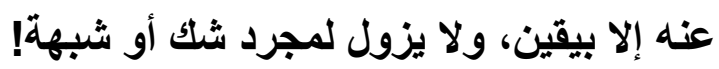

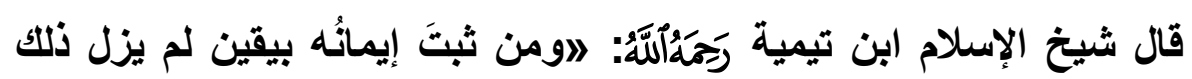

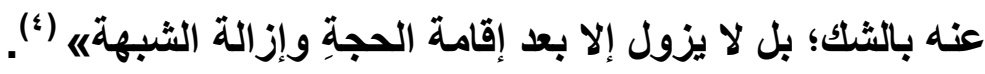

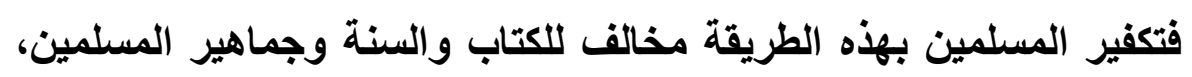

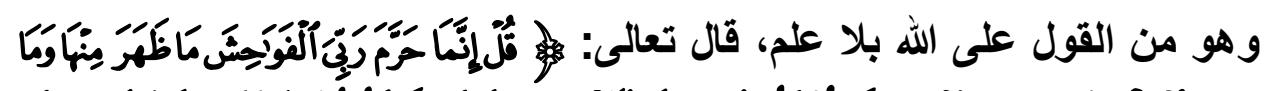

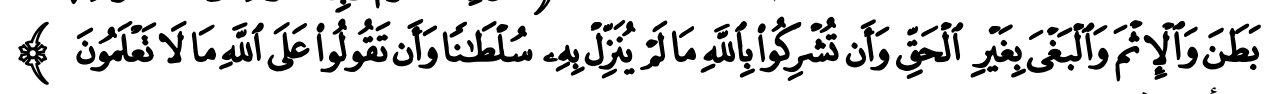

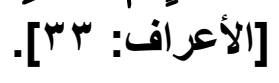

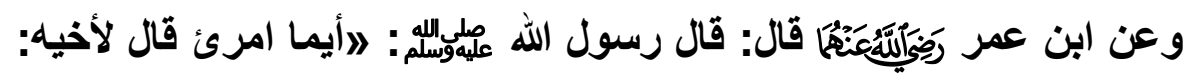

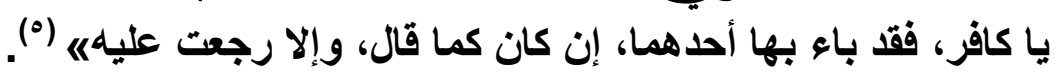

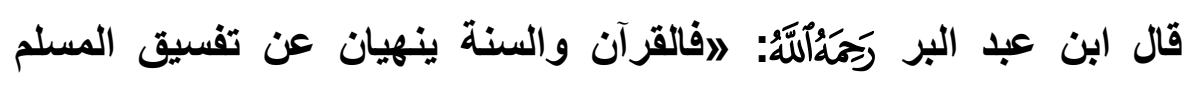
وتكفيره، ببيان لا إثكال فيه ومن جهة النظر الصحيح الذي لا مدفع له؛ أن كل الن

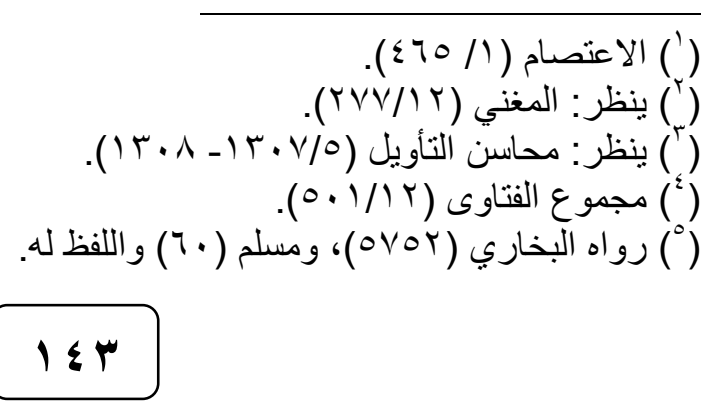


من ثبت له عقد الإسلام في وقت بإجماع من المسلمين ثم أذنب ذنبًا أو تأول

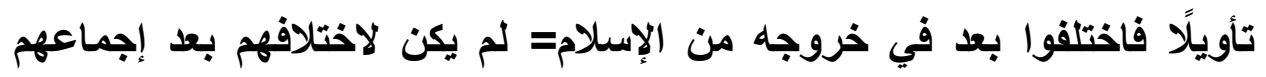

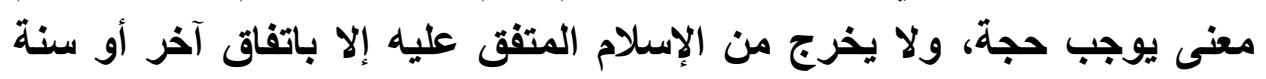

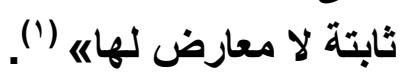

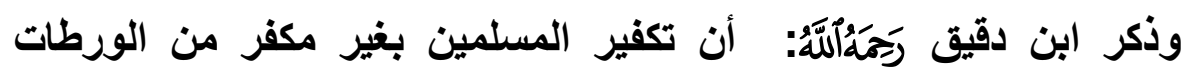

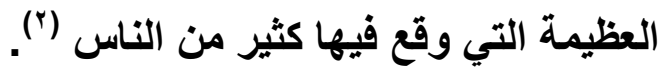

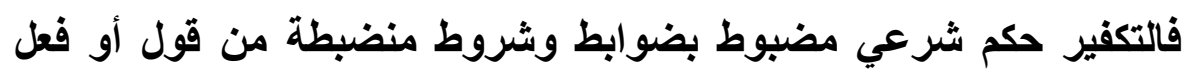

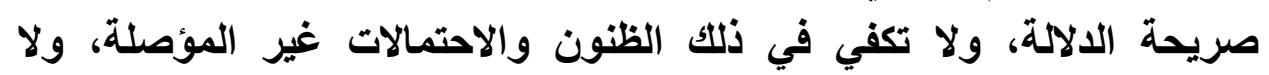

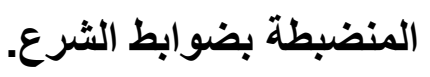

والخلاصة: أنَّ الحكم بالتكفير باللازم من أبطل الباطل، وأن تكفير المسلمين

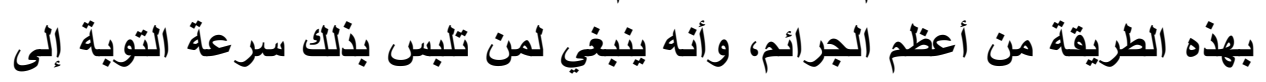

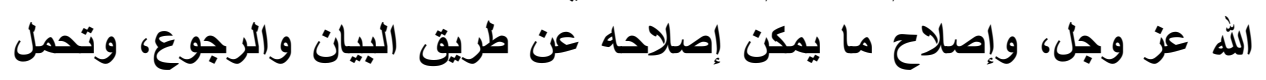
التبعات في ذلك من دماء وأموال ونحوها.

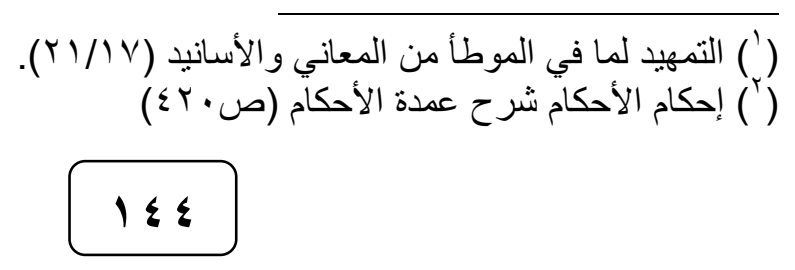




\section{الفاتمة}

$$
\text { أهم التتائج التي توصلتُ إليها: }
$$

أولًا: أنَّ الشبه التي أثارها التظظيم، لا تقوم لها التهة حجة من كتاب أو سنة،

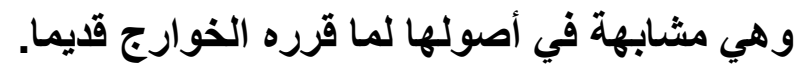

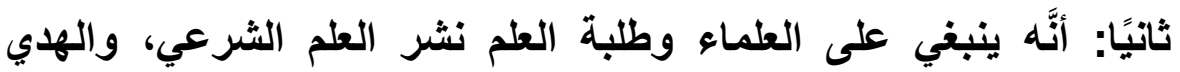
النبوي، وعلم السلف، وبثه بين الناس. ثالثًا: أنَّ إقامة الخلافة ليست مسألة سهلة المنائة لينال، في متناول اليذ؛ بل هي تجري على سنن الله المحكمة، ولا تقوم الدَّول إلا على أسس متينة؛ تحفظ فئه لأفرادها حقهم في دينهم وأنفسهم، وتنظم لهم أمور دنياهم ومصالحهم.

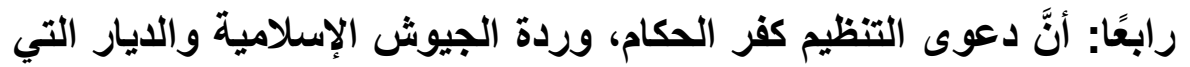

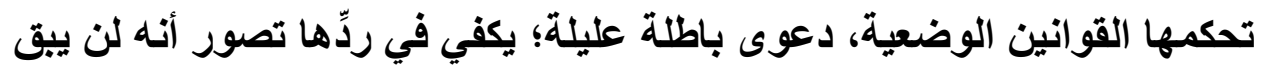

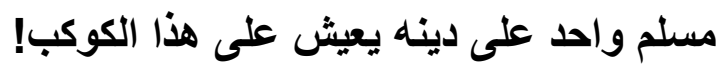

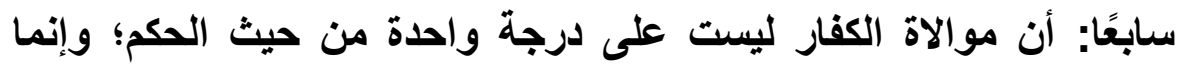

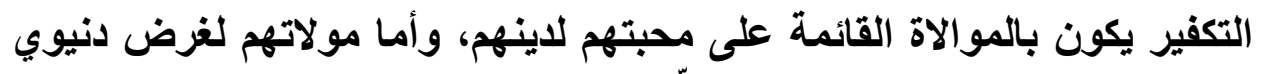
أو شخصي؛ فلا ياخل في الولاء المكفِّ.

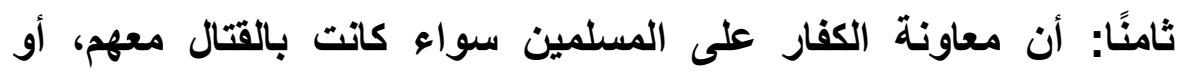

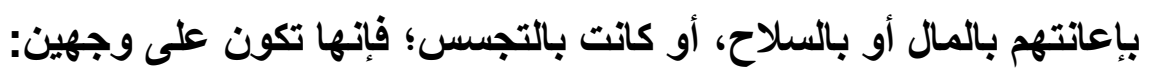

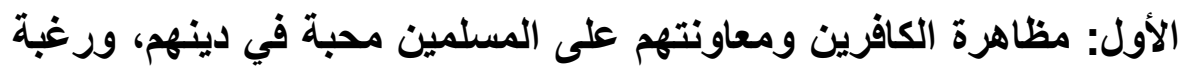
في ظهورهم على المسلمين؛ فهذا كفر مخرج من الملة.

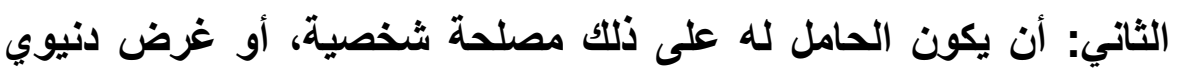

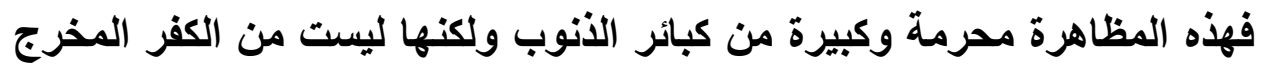
من الملة. تاسعًا: أنَّهُ لا بـ من إقامة الحجة وإزالة المانع على من وقع في مكفر ليس

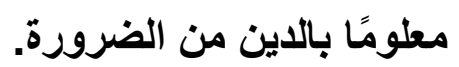

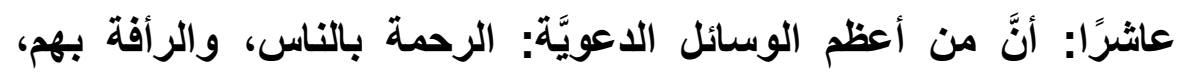

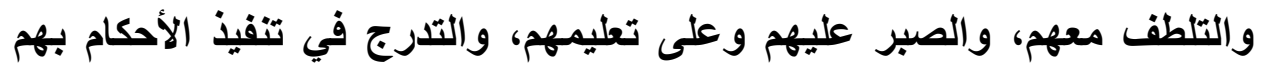

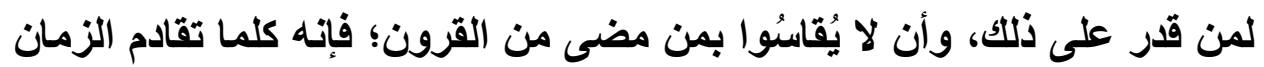
كلما زاد الجهل، واتسعت الهوة بين الناس ودينهم. 


\section{المصادر والمراجير}

0 هاقرار بثأن الإفتاء: شروطه وآدابها لدجمع الفقه الإسلامي الدولي قرار رقم

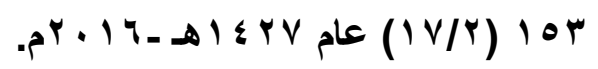
0 o إحكام الأحكام، لابن دقيق العيد، مطبعة السنة المحمدية.

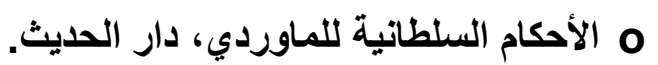
0 أحكام أهل الأمة لابن القيم، ت: يوسف أحمد، رمادي للنشر. م أدب المفتي والمستفتي لابن الصلاح، ت: د. موفق عبد الله، مكتبة العلوم والحكم.

o أساس البلاغة للزمخشري O م الاستذكار

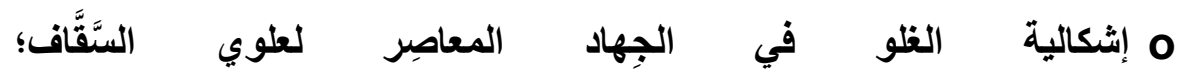
.(https://www.dorar.net/article/1687) o أصول مسائل العقيدة عند السلف وعند المبتدعة د. سعود الخلف 0 أضواء البيان للثنقيطي، دار الفكر. 0 o الاعتصام للشاطبي، ت: سليم الهلالي، دار ابن عفان. دان.

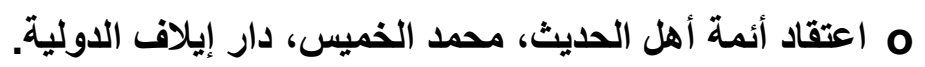

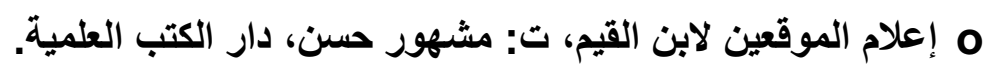
O الأم للثافعي، دار العرفة.

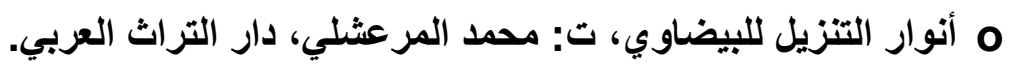
0 أهل الثغور، د. عبد الوهاب الطريري

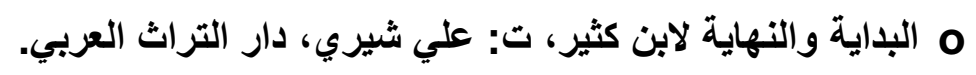

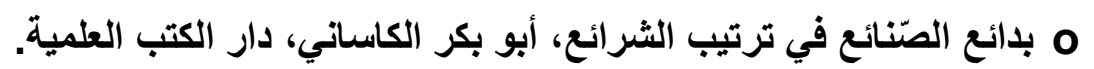
0 تاج العروس للزبيدي، ت: مجموعة من المحققين، دار الهاية. 0 تحفة الحبيب على شرح الخطيب للبجيرمي، دار الفكر.

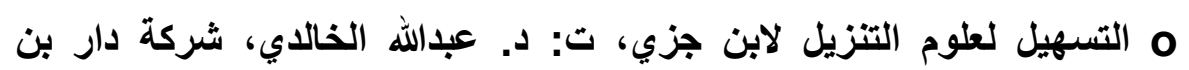

0 التعريفات للجرجاني، دار الكتب العلمية. 0 ت تفسير عبد الرزاق، ت: د. محمود عبده، ط: الأولى، دار الكتب العلمية. 
مجلة كلية الآداب، جامعة سوهاج، العدد السابع والحمسون، الجزء الأول، أكتوبر • • † م

0 تفسيرالنكت والعيون للماوردي، ت: السيد ابن عبد المقصود، دار الكتب العلمية.

o التمهيد لابن عبد البر، ت: مصطفى العلوي، وزارة عموم الأوقاف المغرب. 0 تهذيب اللغة للأزهري، ت: محمد عوض، داري، دار إحباء التراث العربي. 0 ت تيسير الكريم الرحمن للسعدي، ت: عبدالرحمن اللويحق، مؤسسة الرسالة.

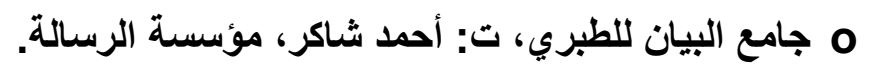

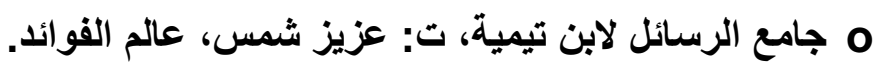
0 الجامع لأحكام القرآن للقرطبي، تالت: أحمد البردوني، دارئ دار الكتب المصرية. 0 الحكم بغير ما أنزل الله د. عبدالرحمن المحمود، دارطيبة. 0 روضة الطالبين وعمدة المفتين للنووي، تات: زهير الثاويش، المكتب الإسلامي.

0 سنن ابن ماجه ، ت: محمد فؤاد عبدالباقي، دار إحياء الكتب العربية. 0 سنن الترمذي، ت: أحمد شاكر، شركة مكتبة ومطبعة مصطفى البابي الحلبي - مصر.

0 سنن الدارمي، ت: حسين الاراني، دار المغني للنشر والتوزيع. 0 سنن النسائي، ت: عبدالفتاح أبو غدة، مكتب المطبوعات الإسلامية - حلب. 0 سير أعلام النبلاء للأهبي، ت: مجموعة من المحققين، مؤسسة الرسالة. 0 السيل الجرار للشوكاني، دار ابن حزم.

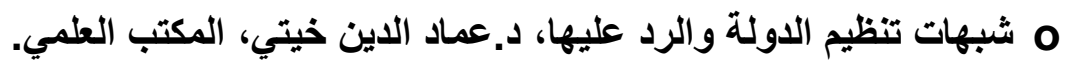
0 شرح السبّيَر الكبير للسرخسي، الثركة الثرقية للإعلانات. 0 شرح النووي على مسلم، دار إحياء التراث العربي. 0 الصحاح في اللغة للجوهري، دار العلم للملايين.

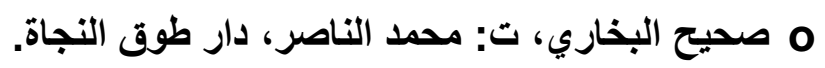

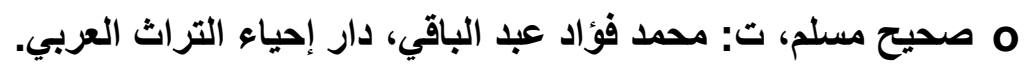
0 صحيح وضعيف سنن ابن ماجه للألباني، برنامج منظومة التحقيقات الحديثية. 0 صحيح وضعيف سنن الترمذي للألباني، برنامج منظومة التحقيقات الحديثية. 0 صحيح وضعيف سنن النسائي للألباني، برنامج منظومة التحقيقات برنامج منظومه الحديثية. 
0 الصواعق المحرقة لابن حجر الهيتمي،ت: عبد الرحمن بن عبد الله التركي، مؤسسة الرسالة. 0 ضوابط التكفير، د.عبد الله القرني، مركز تكوين. o الغلو في الدين في حياة المسلمين المعاصرة، د. فها اللويحق، مؤسسة دونة الرسالة.

o غياث الأمم والتياث الظلم للجويني، ت: عبد العظيم الديب، مكتبة إمام الحرمين. o الفرقان بين أولياء الرحمن وأولياء الثيطان لابن تيمية، مكتبة دار البيان.

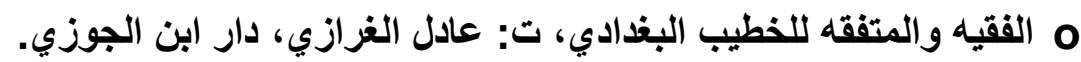
o القول المفيد على كتاب التوحيد لابن عثيمين، دار ابن الجوزي. O الكافية الثافية لابن القيم، مكتبة ابن تيمية، القاهرة. 0 كثاف القتاع للبهوتي، دار الكتب العلمية.

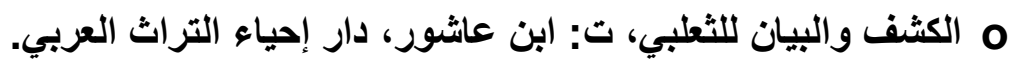

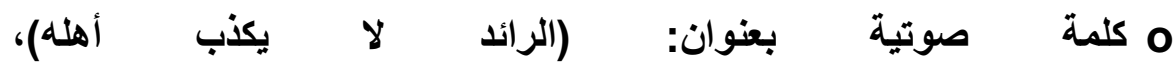
.(https://archive.org/details/3dnani) م كلمة .(https://archive.org/details/El_3dnany4

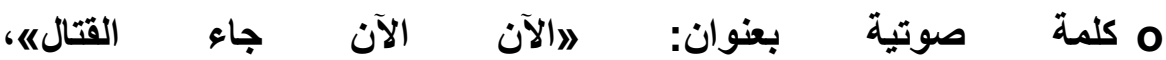
.(https://archive.org/details/ja2.alqetal) o كلمة صوتية بعنوان: 》السلمية دين من؟ه لأبي محمد العدناني (الدقيقة: ؛)، .(https://archive.org/details/slmyh-dn-mn-3dnn)

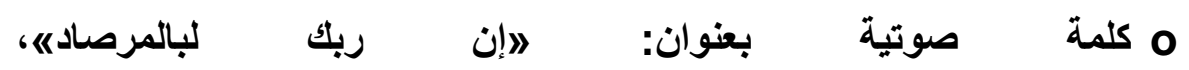
.(https://archive.org/details/kalemahde1)

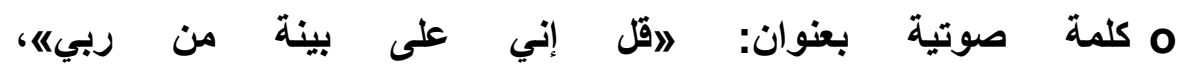
.(https://archive.org/details/byntn) o كلمة صوتيو بعنوان: لاجريمة الانتخابات الثرعية والسياسية، وواجبنا نحوهاه،

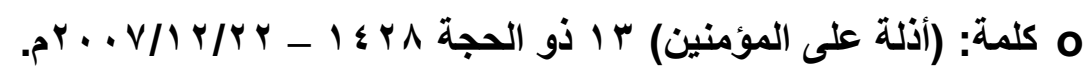




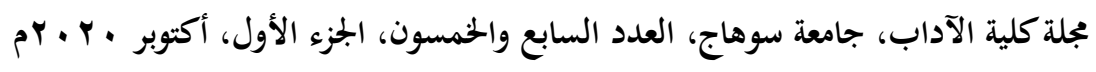
0 لسان العرب لابن منظور، دار صادر - بيروث.

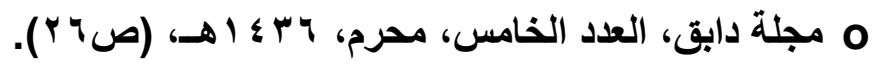

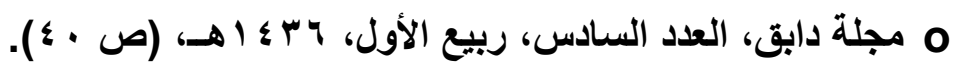
0 مجموع الفتاوى لاب تيمية، ت: عبد الرحمن بن قاسم، مجمع الملك فها. 0 محاسن التأويل للقاسمي، ت: محمد باسل، دار الكتب العلمية. 0 المحرر الوجيز لابن عطية، ت: عبد السلام عبد الثافي، دار الكتب العلمية.

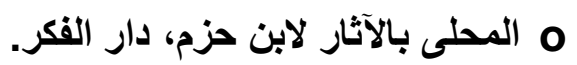
0 مصنف ابن أبي شيبة، ت: كمال يوسف، ط: الأولى، مكتبة الرشند.

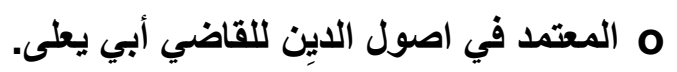
0 المعجم الكبير للطبراني، ت: حمدي السلفي، مكتبة ابن تيمية ـ القاهرة. 0 م المعجم الوسيط، مجمع اللغة العربية بالقاهرة، دار الدعوة. 0 ا مغتي لابن قدامة، مكتبة القاهرة. 0 مفتاح دار السعادة لابن القيم، دار الكتب العلمية.

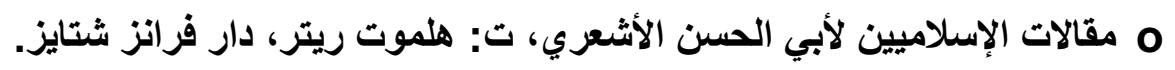
0 مقاييس اللغة لابن فارس، ت: عبد السلام محمد هارون، دار الفكر.

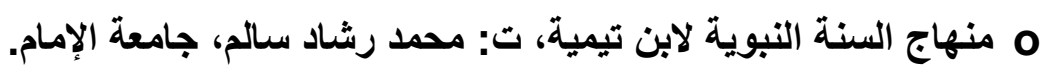

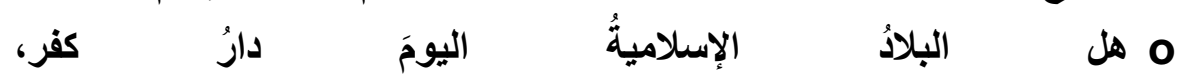
.(https://islamicsham.org/fatawa/3036) 


\section{فهر سر الموضوعات}

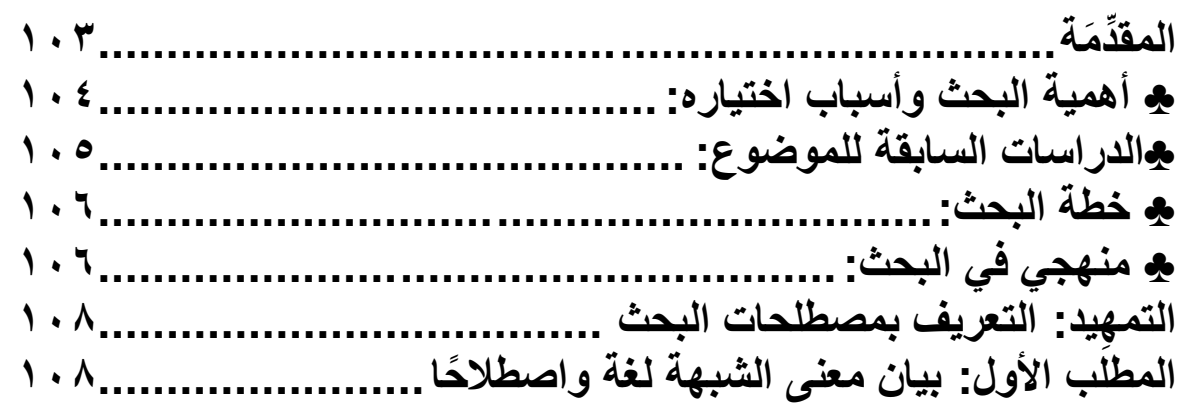

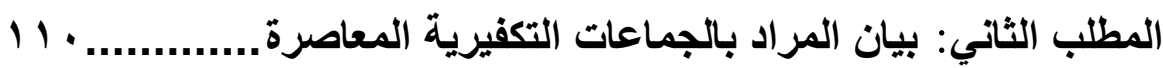

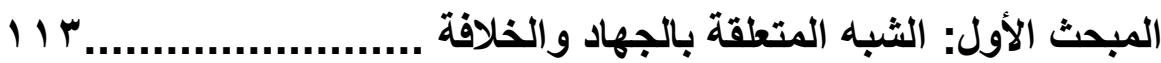

المطلب الأول: شبهة وجوب الالتحاق بالخلافة بعد إعلانها .............

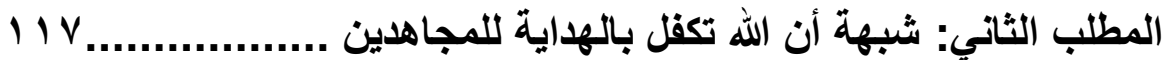

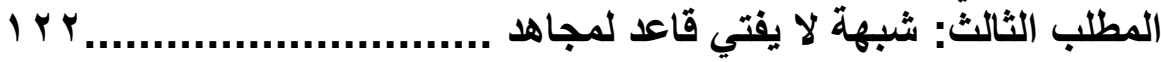
المبحث الثاني: الثبه المتعلقة بالتكفير ...........................................

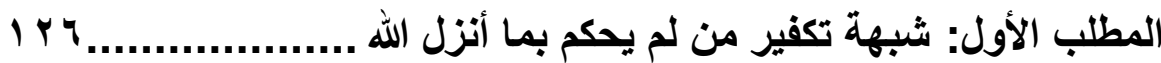

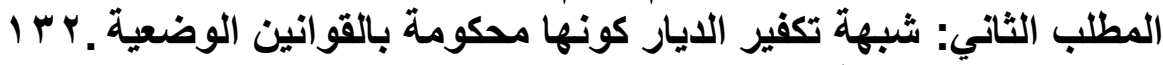

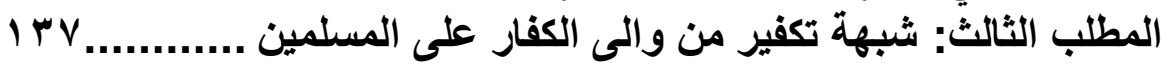

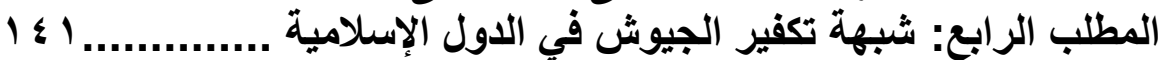

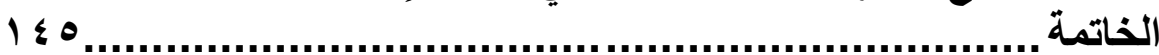
$1 \leq 4$

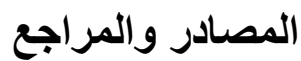

